\title{
A SURVEY OF Forest-MANAGEMENT
}

\section{INFORMATION NEEDS IN BRITISH COLUMBIA}

\author{
Prepared for \\ Southern Interior Forest Extension \\ and Research Parnership
}

By

Robin Gregory \& Terre Satterfield Decision Research

2206 East Mall, $4^{\text {th }}$ Floor

University of British Columbia

Vancouver, B.C. V6T 1Z3

Tel: 604-822-0715

Fax: 604-822-6164

September 30, 1998 


\section{Acknowledgments}

This project was coordinated by Robin Gregory and Terre Satterfield at Decision Research in Vancouver, B.C., and Chris Hollstedt with the Ministry of Forests. As executive director of the Southern Interior Forest Extension and Research Partnership, Chris recognized the need for the client survey in the first place, organized the many focus groups, aided data-collection efforts, reviewed earlier drafts of the report, and put together the sample frame with the assistance of Russ Walton, Ministry of Forests. Her organizational abilities and detailed knowledge of extension services have been invaluable. Kathie Swift, research facilitator with the Interior Lumber Manufacturers' Association, provided astute comments on several drafts of the survey and provided specific criteria for the "Information Needs" questions. C. K. Mertz of Decision Research in Eugene, Oregon aided development of the sampling frame, ran the statistical analyses for all the survey data, and wrote much of Chapter 2. Her input has been essential to the success of this effort. Jim Flynn of Decision Research provided helpful comments on the survey design. Leisha Mullican and Janet Douglas, also of Decision Research, provided great technical support on presentation of the figures and were enormously productive under severe time constraints. Gregory and Satterfield were responsible for all other aspects of the survey research, design, interpretation, analysis, and writing.

We would also like to thank the many members of the Southern Interior Partnership who generously gave of their time and knowledge as part of small group discussions, interviews, and formal review of survey drafts. It is our hope that they will recognize their input into this report and find its results helpful. 


\section{Table of Contents}

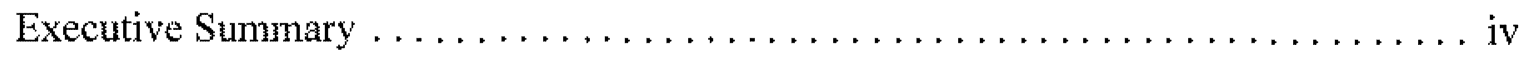

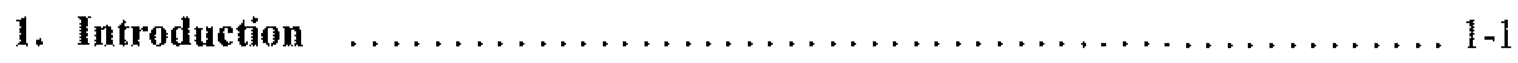

2. Methods

2.1 Focus groups $\ldots \ldots \ldots \ldots \ldots \ldots \ldots \ldots \ldots \ldots \ldots \ldots \ldots \ldots \ldots \ldots \ldots \ldots, 1$

2.2 Sampling $\ldots \ldots \ldots \ldots \ldots \ldots \ldots \ldots \ldots \ldots \ldots \ldots \ldots, 2-2$

3. Objectives/Goals

3.1 Relative Importance of Objectives $\ldots \ldots \ldots \ldots \ldots \ldots \ldots \ldots \ldots \ldots, 3-1$

3.2 Differences Across Partnership Groups $\ldots \ldots \ldots \ldots \ldots \ldots \ldots \ldots . . \ldots \ldots$

3.3 Regional Differences ..., ......................... 3-6

\section{Information Needs}

4.1 Habitat, Species, and Water Resources . . . . . . . . . . . . . . . 4-2

4.2 Timber Harvest and Management $\ldots \ldots \ldots \ldots \ldots \ldots \ldots \ldots \ldots, 4,4$

4.3 Economic, Social, and Cultural Factors . . . . . . . . . . . . . . . 7

4.4 Support for First Nation Information Needs . . . . . . . . . . . . . 4-10

\section{Communication}

5.1 Availability and Accessibility of Information $\ldots \ldots \ldots \ldots \ldots \ldots, 5-1$

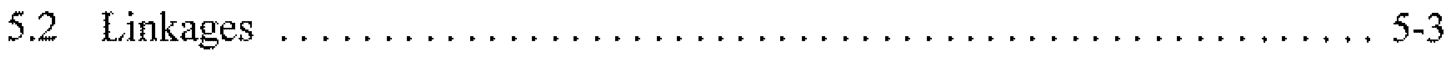

\section{Quality of Information}

6.1 Presentation of Information $\ldots \ldots \ldots \ldots \ldots \ldots \ldots \ldots, \ldots, \ldots, 1$

6.2 Trust in the Information Source $\ldots \ldots \ldots, \ldots \ldots \ldots \ldots, 6,4$

\section{Technology Transfer}

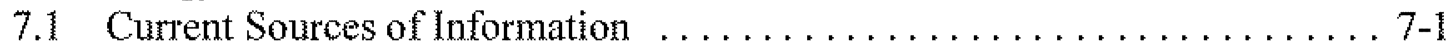

7.2 Preferred Methods of Information Transfer $\ldots \ldots \ldots \ldots \ldots \ldots \ldots \ldots, 7-7$

7.3 Tradeoffs Across Technology Transfer Options $\quad \ldots \ldots \ldots \ldots \ldots \ldots, 7-11$

7.4 Location of Extension Staff $\ldots \ldots \ldots \ldots \ldots \ldots \ldots \ldots \ldots \ldots \ldots \ldots, 7-13$

8. Conclusion $\ldots \ldots \ldots \ldots \ldots \ldots \ldots \ldots \ldots \ldots \ldots \ldots \ldots \ldots \ldots, \ldots \ldots \ldots \ldots \ldots \ldots, 1$

Appendix A - Client Needs Survey

Appendix B - Cost Considerations (Figures B.1 through B.3) 


\section{Executive Summary}

This report presents the results of a survey of client needs that was conducted by Decision Science Research Institute on behalf of the Southern Intcrior Forest Extension and Research Partnership. The survey was designed to identify the primary information needs of Partnership members; to define the key barriers limiting access to rclevant information; to determine the perceived quality of, and users' trust in, various sources of information; and to understand better the opinions of Partnership clicnts regarding altcrnative presentation formats and different options for the dissemination of selected information types.

Background research and extensive small-group discussions provided an initial framework for the survey, which was pilot tested and then mailed to a random selection of 1,357 Partnership members in June, 1998. A total of 381 completed surveys (an overall response rate of $28.1 \%$ ) were obtained from a broadly representative sample of partnership members including provincial operations and policy personnel (from the Ministry of Forests, the Ministry of Agriculture and Food, and the Ministry of Environment, Lands, and Parks), provincial rescarchers (from the same agencies), timber licensees, private consultants, and other (academic and federal government) researchers. In addition, smaller samples were obtaincd from selected First Nation groups (Shuswap Nation Tribal Council and the Okanagan Nation Alliance) and from nongovernmental organizations (NGOS).

The survey results demonstrate broad agrecment on the overall goals and objectives of an extension service for the Southern Interior of the province. Emphasis is placed on getting information effectivcly from experts or other reliable sources of information to potential users and on the continued development of a responsive knowledge base. Recent changes in forestry practices in the Province are shown to have resulted in a pressing need for additional information relating to the application of sustainable forest practices, the incorporation of First Nations in forest-management decisions, and the need to achieve on-the-ground practices that are scientifically defcnsible and socially, legally, and ecologically viable. Survey results point to substantial disagreements among Parmership clients regarding the priorities that should in future be assigned to these diverse extension services. In addition, the results show striking differences in the perceptions of key groups regarding the performance of extension services in focusing on the issues of primary importance to Partnership clients, employing accessible presentation formats, and utilizing appropriate dissemination technologies. 


\section{1}

\section{Introduction}

Beginning in 1997, the Ministry of Forests, supported by Forest Renewal B.C. and the Science Council B.C., convened the Southern Interior Forest Extension and Research Partnership (hereafter referred to as the Partnership) for the purposes of developing, exchanging, and using knowledge about sustainable natural-resource management. Private and public sector land managers, government resouree professionals, consultants, and federal-, provincial-, college- and university-based researchers recognize that, although a significant knowledge base exists, important information about forest resources is insufficiently shared and sometimes difficult to access. As a result, resource management knowledge is not contributing as fully as possible to the use and conservation of British Columbia's forests.

In February of 1998 the Partnership stated among its goals the desire to identify the types of knowledge products required by forest and range management practitioners in the Southern Interior, to establish a comnon forum for delivery of extension products to users, and to enhance the extension capability in the Southern Interior by accommodating a diversity of technology transfer needs. In June and July of 1998, a survey was conducted by Decision Science Research Institute, contracted by Ministry of Forests, to help serve these basic aims of the Partnership. This report demonstrates, through text and figures, the findings of that survey by addressing the following questions:

1. What arc the primary goals of a Southern Interior Extension Service as identified by different members of the Partnership?

2. What are the primary information needs as identified by different Partnership members?

3. Do partnership nembers believe that specific factors reduce the potential benefits of the extension service because they make it more difficult for some clients to access information? 
4. Are linkages between research-based and opcrations-based sectors of the Partnership set up such that productive information exehanges take place?

5. How do variations in the presentation of information affect its use?

6. Given the large variety of options for delivering, disseminating or transferring information to different users, are some methods of transfer preferred over others? If so, why?

Our work on the survey began with background research on existing findings about research and extension needs, focusing on studies already conducted for land managers in British Columbia and other provinces. In particular, we reviewed the following documents: Crown Range Research and Extension Review Project: Steering Committee Report, January 26, 1995 (Russ Horton: BC Ministry of Forests); BC Forest Workers Training Strategy, BC Forestry Continuing Studies Network: Ecological Inventory Training Needs Analysis, Prepared by D. Underhill, T. Chandler, and H. Deal; Regional Research Advisory Committee (RRAC) Summary of 1996 Meetings, Jane Perry, R.P.F., August, 1996; Landscape Ecology: Assessment of Research Extension Needs, Ministry of Forests, Research Branch, August, 1995; Proposal for a Southern Interior Forest Science Partnership, May, 1997; Problem Analysis of Integrated Resource Management of Riparian Areas in British Columbia, BC Ministry of Forests Research Program; Evaluation of Biodiversity Publications: A Survey of Users, Graham Shuley, August, 1997; VMAP: Client Needs Survey, Ontario Forest Research Institute, Ontario Ministry of Forests; and the Five Year Forest and Range Resource Program 1997-2002, BC Ministry of Forests: Corporate Policy and Planning. The review process led us to conclude that while B.C.'s land managers had identified a range of research need, the existing inventories were often so detailed that they were unwieldy and could not sufficiently inform broader, crossm Partnership needs. Thus, an important aim of the new survey was to develop an ordering mechanism for developing extension via the identification of basic extension goals and communication problems. This work provides a framework with which to prioritize decisions about extension (and technology transfer) given limited public resources. We also recognized that no significant effort had been taken to identify the differences of opinion across different extension elient or user groups. If tcchnology preferences or extension goals vary according to client groups, then those differenees must be addressed by the emerging Partnership service. Several prior efforts had also been made to rank information needs; we hope to further those cfforts by providing percent distributions so as to clarify the magnitude of support for different information priorities. Finally, while providing information is essential to any extension service, little was known about Partnership clients" nced for decision tools to utilize that information or the types of assistance reguired to interpret case-specific applications. 
Bearing these considerations in mind, work progressed from the review process to a series of interview and small group discussions in Kamloops, Nelson, Willians Lake, and Victoria. The interview and small group work was designed to elicit clients' primary concerns about the development of, availability of, and access to information that would improve the management of B.C.'s resources. Discussions focused upon, but were not limited to, the relationship between information users and providers, recommendations for the design and implementation of an extension service, impressions about the communication successes and failures of existing vehicles for the exchange of information, brainstorming about what constitutes good quality information, and discussions about what makes a particular source of information worthy of trust and thus likely to be used.

When these two background stages were complete, the project team developed and circulated for comments four successive versions of the survey. These drafts were reviewed by extension specialists, Partnership representatives, and different members of the Ministry of Forests research and operations branches. In addition, the instrument was pilot tested for comprehension, content and ease of use and in both Vancouver and Kamloops.

The survey was mailed to a random selection of 1,357 Partnership members distributed across key member groups. An overall response rate of $28.1 \%$ was achieved. The sampling and survey methods are discussed in more detail in Chapter 2. 


\section{2}

\section{Methods}

The study team faced two initial tasks in designing the Partnership survey. First, it was important that key issues be defined and presented in sufficient detail such that participants' input would directly assist in the devclopment of new extension services. Second, it was important that a representative sample of views be obtaincd from clients of the Southem Interior Forest Extension and Research Partnership. This chapter provides a brief summary of the focus groups that were used to design the initial survey content and of the sampling procedures used to generate defensible responses from the selected target population.

\section{1 Focus groups}

A key step in the development of the Partnership survey was a series of focus groups held in three different locations with representatives of the primary client groups. In each case, the groups involved between five and fifteen participants and were facilitated by members of the study team. The first three focus groups were held in Kamloops, Nelson, and Williams Lake and, in each case, included a broadly representative sampling of Partnership clients. A separate group was subsequently held in Kamloops with representatives from the Shuswap Nation Tribal Council and the Okanagan Nation Alliance. Their views were informative but not interpreted as the views of all Southern Interior aboriginals. Additional interviews were held during this same period of time with key individuals working for the Ministry of Forests and Forest Renewal B. C. in Victoria and with university researchers and members of the Continuing Studies Network in Vancouver.

The discussions in these groups followed a series of questions developed by the study team that were intended to faclitate an open exchange of views on key issues relating to design of the client needs survey. Participants were reminded at the start that they were the expers in the content of the survey and that its results would be useful only if the questions spoke to issues important to those around the table. These issues included 
perceived information needs, pros and cons of alternative communication options, concerns regarding the quality of information, and comparisons of technology transfer alternatives. Participants in these pre-survey focus groups also were asked to inform the study team about what they saw as key issues in the design of a new, nore effective extension service and to openly discuss both opportunities for extension and perceived barriers to its future success. As the conversations unfolded, participants were asked to expand on their views, to present additional details when this would be helpful, and to provide feedback to the study team on the quality of its understanding.

\subsection{Sampling}

The target population for this survey was the membership of the Southern Interior Forest Extension and Research Partnership. This partnership is made up of 14 categories of participants. These groups of participants were classified into six major groups with the following designations:

1. Licensees (includes minor and major licensees and woodlot owners)

2. Private consultants (including contractors)

3. Provincial government. This group ineludes operations, policy and research personnel in the Ministry of Forests, Ministry of Environment, Lands and Parks (MELP): and Ministry of Agriculture and Food $(\mathrm{M}$ of $\mathrm{Ag}) .{ }^{5}$ Both Victoria-based and Southern Interior regions were included.

4. Other researchers in academia and the federal government

5. First Nations. The sample of First Nation respondents is very small ( $N=13$, see Table 2.2), thus these results are used sparingly and tentatively in this report. The need for additional information on extension priorities specific to First Nations is of first-order importance and should be pursued by the Ministry of Forests and other interested parties. This need is reiterated elsewhere in this report and in the conclusion.

6. Nongovernment organizations (NGO). The effort to pursue $\mathrm{NGO}$ respondents was experimental; given the small sample $(N=10$; see Table 2.2) and the experimental nature of this effort. NGOs are not discussed as a separate subgroup in this report. They are lowever included in findings based on the entire sample $(N=381$, see Table 2.2).

\footnotetext{
${ }^{1}$ Most of this subsample (78.4\%) is, however, comprised of Ministry of Forests personnel.
} 
Table 2.1 provides a brief description of each group and the sources or databases from which potential respondents were drawn. This sampling frame was provided to Deeision Research by the Southern Interior Forest Extension and Research Partnership. It was assembled from several mailing lists and cross-checked for duplicate names. The primary data sources were the Provincial Government Telephone Direetory, Ministry of Forests Client lists (MOF), Consulting Foresters of B.C. Directory, Canadian Forest Service Mailing List (CFS), B.C. Environment Report, Federation of B.C. Naturalist's Club List, academic institution calendars, and the Forestry Continuing Studies Network Mailing list $(\mathrm{FCSN})$. 
Table 2.1 Description of Groups and Data Sources

\begin{tabular}{|c|c|c|c|}
\hline Group & Category & Description & Data Source \\
\hline Licensees & $\begin{array}{l}\text { 1. Minor licensee } \\
\text { 2. Major licensee } \\
\text { 3. Woodlot owners }\end{array}$ & $\begin{array}{l}\text { Major and minor forest } \\
\text { licensees, including } \\
\text { sawmills, some } \\
\text { manufacturing plants, and } \\
\text { individuals with woodlot } \\
\text { licenses. }\end{array}$ & $\begin{array}{l}\text { MOF mailing list; FCSN, } \\
\text { CFS mailing lists. }\end{array}$ \\
\hline $\begin{array}{l}\text { Private } \\
\text { Consultants }\end{array}$ & $\begin{array}{l}\text { 4. Private sector } \\
\text { contractors } \\
\text { 5. Consultants }\end{array}$ & $\begin{array}{l}\text { Small business consul- } \\
\text { tants, contractors } \\
\text { including, loggers, } \\
\text { engineering firms, } \\
\text { surveyors, nurseries, } \\
\text { planting operations, and } \\
\text { trucking companies. }\end{array}$ & $\begin{array}{l}\text { MOF mailing list (small } \\
\text { business file); FCSN. }\end{array}$ \\
\hline $\begin{array}{l}\text { Provincial } \\
\text { Govertument }\end{array}$ & $\begin{array}{l}\text { 6. MOF: operations } \\
\text { 7. MOF: research } \\
\text { (Victoria and non } \\
\text { Victoria) } \\
\text { 8. MELP } \\
\text { 9. M. of Agriculture }\end{array}$ & $\begin{array}{l}\text { Provincial government } \\
\text { employecs involved in } \\
\text { research, policy, or } \\
\text { enforcement in the } \\
\text { Ministry of Forests, } \\
\text { MELP, and Ministry of } \\
\text { Agriculture }\end{array}$ & $\begin{array}{l}\text { Provincial Government } \\
\text { Directory (January 1998). }\end{array}$ \\
\hline $\begin{array}{l}\text { Other } \\
\text { Researchers }\end{array}$ & $\begin{array}{l}\text { 11. Federal } \\
\text { government } \\
\text { 12. Academics }\end{array}$ & $\begin{array}{l}\text { Federal government } \\
\text { researchers and fullutime } \\
\text { faculty with academic } \\
\text { institutions }\end{array}$ & $\begin{array}{l}\text { Federal government in- } \\
\text { house phone book for } \\
\text { fisheries data; Pacific } \\
\text { Forestry Centre for Federal } \\
\text { Forestry Researchers. } \\
\text { Academic calendars and } \\
\text { institutional web-sites for } \\
\text { faculty in biology, forestry, } \\
\text { resource management, } \\
\text { geography and chemistry. }\end{array}$ \\
\hline First Nation & 13. First Nation & First Nation groups & $\begin{array}{l}\text { FCSN file and MOF } \\
\text { mailing list. }\end{array}$ \\
\hline $\mathrm{NGO}^{\prime} \mathrm{s}$ & 14. NGO's & $\begin{array}{l}\text { Nongovernmental } \\
\text { organizations }\end{array}$ & $\begin{array}{l}\text { Fedcration of BC } \\
\text { Naturalist's Club List; } \\
\text { Cariboo Conservation } \\
\text { Society mailing list; and } \\
\text { some from FCSN list. }\end{array}$ \\
\hline
\end{tabular}


The sampling frame produced 4,260 possible names/contacts, as shown in Table 2.2, column 4 . To ensure comprehensive and meaningful responses across the sample, the study team sought to obtain responses from each of the 14 groups and collect a total of about 345 completed surveys. A target number of completed surveys was designated for each group (Column 5). A judgmental estimate of the likely response rate for a single mailing with one pre-notification letter was made (Column 6). The estimated response rate times the targeted number of completed surveys for each of the 14 groups produced the parameters for the sample (Column 7). Specific addresses were randomly selected from each group as shown in Column 7; all surveys were mailed. The number of completed surveys returned for each group is shown in Column 8. Columns 7 and 8 produced the data for calculating the response rate for groups as shown in Column 9. This stratified random sampling procedure produced a sample frame of 1,357 and resulted in 381 completed surveys with an overall response rate of $28.1 \%$. The response rates ranged from $8.0 \%$ for the for the Private Sector contractors to $82.1 \%$ for the Ministry of Forests, non-Victoria research population.

A prenotification letter was sent to each person in the sample frame on May 25, 1998; this was followed by a single mailing of the survey instrument on June 5, 1998. All responses were collected in June and July, 1998 . Males provided $77.2 \%$ of the completed surveys; females $18.6 \%$; the mean age was 43.1 .

The margin of error for the total sample of 381 is $5.1 \%$ at the $95 \%$ confidence interval. 
Table 2.2. Sampling Frame and Response Rate

\begin{tabular}{|c|c|c|c|c|c|c|c|c|}
\hline Group & $\begin{array}{c}\text { Sub- } \\
\text { sample }\end{array}$ & Category & Frame & $\begin{array}{l}\text { Desired } \\
\text { sample }\end{array}$ & $\begin{array}{c}\text { Estimated } \\
\text { Response } \\
\text { Rate }\end{array}$ & $\begin{array}{l}\text { Sample } \\
\text { Frame }\end{array}$ & $\begin{array}{c}\text { Final } \\
\text { Responses }\end{array}$ & $\begin{array}{l}\text { Response } \\
\text { Rate }\end{array}$ \\
\hline \multirow[t]{4}{*}{ Licensee } & 1 & Minor Licensees & 263 & 15 & 20 & 75 & 9 & $12.0 \%$ \\
\hline & 2 & Woodlot Owners & 247 & 15 & 20 & 75 & 20 & $26.7 \%$ \\
\hline & 3 & Major Licensees & 244 & 20 & 20 & 100 & 34 & $34.0 \%$ \\
\hline & & Subtotal & 754 & 50 & 20 & 250 & 63 & $25.2 \%$ \\
\hline Private & 4 & \multicolumn{2}{|l|}{ Private Sector (90)/ } & & & & & \\
\hline \multirow[t]{3}{*}{ Consultant } & 4 & $\begin{array}{l}\text { Contractors } \\
(1028)\end{array}$ & 1,118 & 30 & 20 & 150 & 12 & $8.0 \%$ \\
\hline & \multirow[t]{2}{*}{5} & Consultants & 266 & 20 & 20 & 100 & 36 & $36.0 \%$ \\
\hline & & Subtotal & 1,384 & 50 & 20 & 250 & 48 & $19.2 \%$ \\
\hline Provincial & & Provincial Govt & & & & & & \\
\hline \multirow[t]{6}{*}{ Government } & 6 & $\begin{array}{l}\text { MOF operations } \\
\text { MOF research }\end{array}$ & 1,087 & 43 & 25 & 172 & $85^{: 4}$ & $49.4 \%$ \\
\hline & 7 & .5 Vctoria & 108 & 21 & 25 & 108 & 48 & $44.4 \%$ \\
\hline & 8 & .5 Non-Victoria & 28 & 21 & 25 & 28 & 23 & $82.1 \%$ \\
\hline & 9 & MELP & 510 & 40 & 25 & 160 & 30 & $18.8 \%$ \\
\hline & \multirow[t]{2}{*}{10} & $\mathrm{MAg}^{\mathrm{b}}$ & 30 & 15 & 25 & 30 & 13 & $43.3 \%$ \\
\hline & & Subtotal & 1,763 & 140 & 25 & 498 & 199 & $40.0 \%$ \\
\hline Other & 11 & Federal Govt (63)/ & & & & & & \\
\hline \multirow[t]{2}{*}{ Researchers } & 12 & Academics (131) & 194 & 40 & 20 & 194 & 48 & $24.7 \%$ \\
\hline & & Subtotal & 194 & 40 & 20 & 194 & 48 & $24.7 \%$ \\
\hline $\begin{array}{l}\text { First } \\
\text { Nations }\end{array}$ & $\$ 3$ & First Nations & 87 & 40 & 30 & 87 & 13 & $14,9 \%$ \\
\hline \multirow[t]{2}{*}{ NGO } & 14 & NGOS & 78 & 25 & 25 & 78 & 10 & $12.8 \%$ \\
\hline & & TOTAL & 4,095 & 280 & 25 & 1,192 & 358 & $30.0 \%$ \\
\hline
\end{tabular}

\footnotetext{
${ }^{a}$ Note that MOF Operations is the largest single stugroup $(n=85)$ and thus has the largest single impact on entre sample reporting in subsequent chapters. The same is true of the Provincial Government cluster as a whole.

${ }^{b}$ A few respondents ( $n=6$ ) from MELP and M Ag identified themselves as researchers and thus bring the fotal number of provincial researchers to $77(48+23+6)$.

This subsample is comprised of representatives from the Shuswap Nation Tribal Council and the Okanagan Nation Alliance.

The high return rate for MOF non-Victoria research is not sufficient to alter the response pattern for the combined responses of all survey participants.

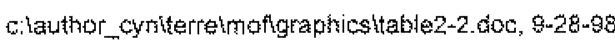




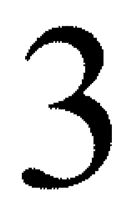

\title{
Objectives/Goals
}

The formation of the Southern Interior Partnership was borne of the shared belief that a diverse coalition of forest management stewards could benefit from an organized capacity to develop and exchange information. Ultimately, the Partnership must service the goals of its constituents yet recognize that the objectives of its component parties will vary. To understand these differences, a first section of the Client Needs Survey presented respondents with a spectrum of 11 basic extension service goals. Together they represent the foundational premise, or the basic underpinnings, for the eventual extension service. The specific expression of the goals was derived from the small group discussions that preceded the design of the survey.

\section{1 Relative Importance of Objectives}

Respondents were asked to rate each goal using a 10-point scale with "very unimportant" and "very important" as the two endpoints. The exact directions were as follows:

\begin{abstract}
Listed below are several possible goals for the new Southern Interior extension program. Please read through all of the items before you begin. Then rate each extension service goal where " 10 " equals those few items that are "very important" to you and a "1" equals those that are "very unimportant" to you All others should be rated sonewhere in between."
\end{abstract}

Figure 3.1 depicts the percent of respondents who rated each goal a maximum score of 10 or "very important" on the 10 point scale. Three goals stand out as most important relative to all other goals, in that between $31.5 \%$ and $45 \%$ of all respondents assigned a rating of 10 to the following goals:

\footnotetext{
' The exact wording of the goals is included in Appendix A, questions 4 through 14 .
} 
Extension services should focus on getting information from experts into the hands of interested users

The extension service should be able to link the person with a problem or question to those with the best available information

Extension services should stupport the ongoing development of knowledge and research

The extension service should focus on improving public knowledge about forest science and management

Researchers within the Partnership should base their goals on the needs of the Parnership members

The extension service should set up and run a central clearing house or "library" of resoutce-management information

The primary goal of extension services is to simplify and interpret technical information

The new extension service should provide support for individual and group decision-making processes

Extension services shoutd focus on the scientific testing of guidelines set ouf in the B.C. Forest Practices Code

Partnership researchers should focus on the interpretation of guidelines set out in the B.C. Forest Practices Code

The extension service should de-emphasize new tesearch and focus instead on applying existing information to forest-management decisions

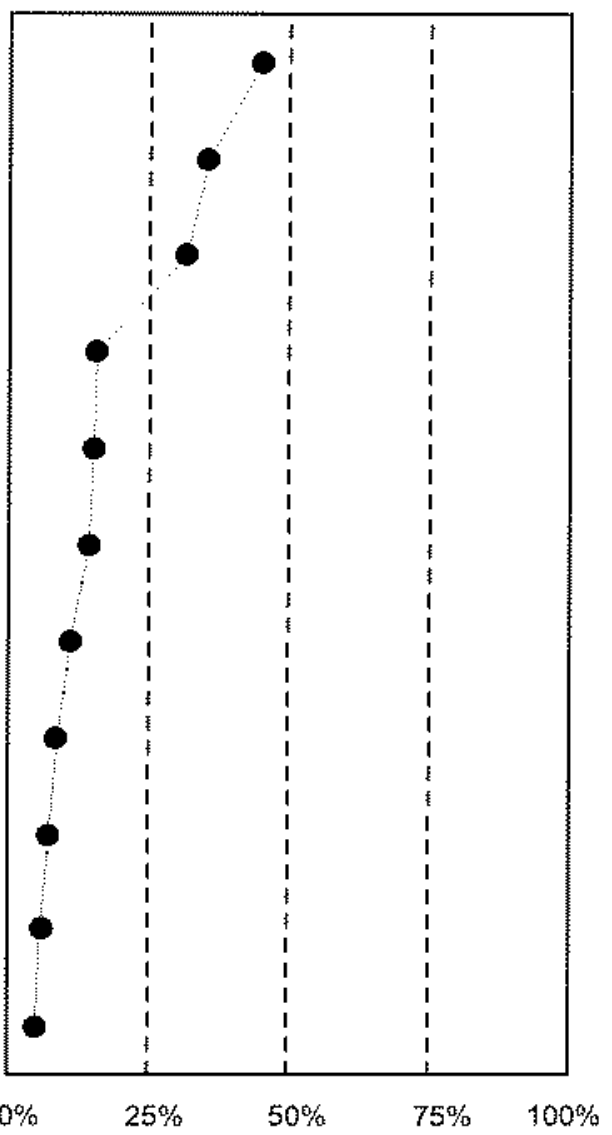

Percent very important

Figure 3.1. Extension goals. Percent who circled 10 on a 10-point scale from 1 (very unimportant) to 10 (very important). $(\mathrm{N}=381$ )

Source: Decision Research, Southern Interior Forest Extension Survey (1998).

- Extension services should focus on getting information from experts into the hands of interested users [44.9\%]

- The extension service should be able to link the person with a problem or question to those with the best available information [35.4\%]

- Extenston services should support the ongoing development of knowledge and research $[31.5 \%]$ 
Each of the other eight goals received "very important" ratings from $15.5 \%$ or less of respondcnts, though it should be noted that a rating of 10 represents the extreme of a 10 point scale.

The position of the three top goals in the ordinal ranking of all eleven goals does not change when considering the percent frequency distributions for respondents who offered each goal an 8,9 or 10 ranking, nor does it change if one calculates the mean response of all offered rankings for each goal. Figure 3.2 below represents the frequency distributions for goals that were assigned an importance score of 8 or better.

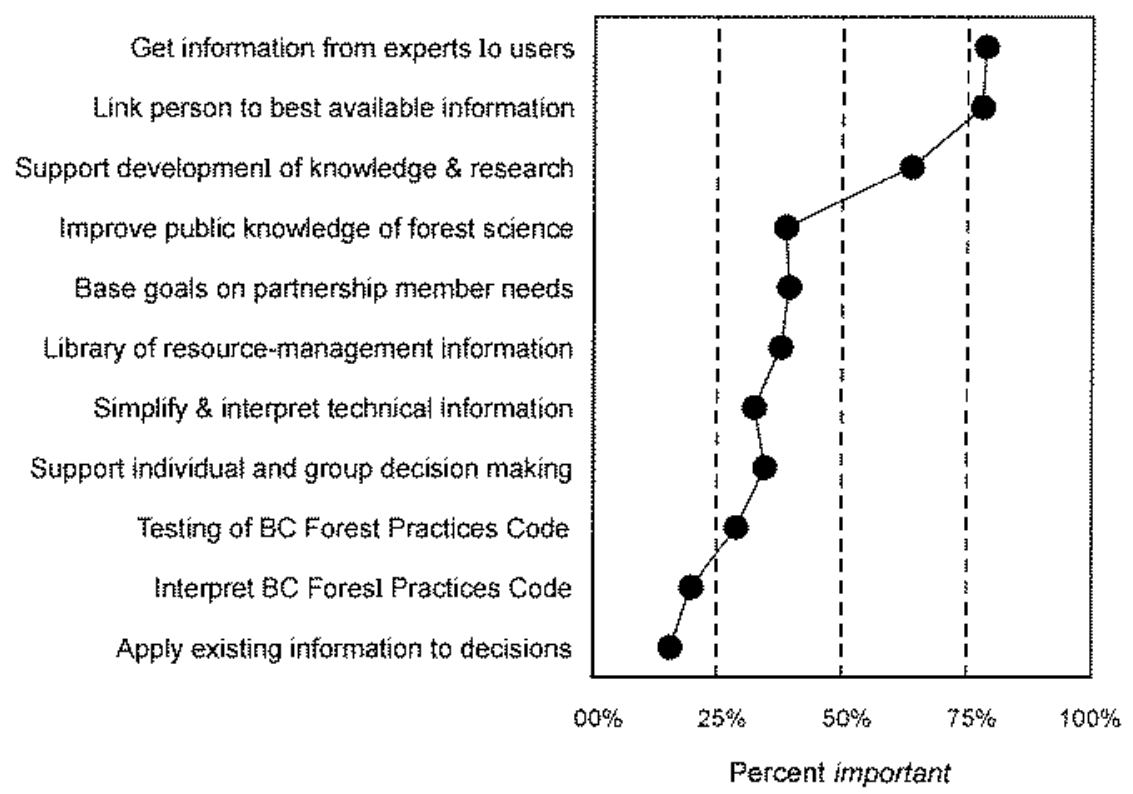

Figure 3.2. Extension goals. Percent who circled 8, 9, of 10 on a 10 -point scale from 1 (very unimportant) to 10 (very important). $(\mathrm{N}=381$ )

Source: Decision Research, Southern interior Forest Extension Survey (1998),

Moreover, the differences between goals with regard to assigned importance becomes apparent when the frequency distribution for goals that achieved scores of 8,9 or 10 are compared. The first two of the above three goals (getting information from experts to users and linking the person with a problem or question to those with the best available informationj emerge as highly relevant in that $78 \%$ of respondents rated each as "important" through a score of 8 or better. The third goal emerges as important though slightly less primary at $63.8 \%$, while all other goals fall well below the $40 \%$ mark and thus are viewed by only a minority of respondents as important. Five goals, such as improving public knowledge of forest science and the interpretation of technical information, are regarded as important by $30 \%$ to $40 \%$ of respondents. 


\subsection{Differences Across Partnership Groups}

During the presurvey small group work with private and public sector Partnership clients, intergroup conflicts about the basic design, management and goals of a Southern Interior extension service were apparent. Most obviously, licensees and operations personnel disagreed with research personnel about the degree to which a research agenda should be driven by the problems facing operations specialists and licensees, about the need for expert support when making forest management decisions within the B.C. Forest Practices guidelines, and about the wisdom of central clearing houses or libraries of technical information. Figure 3.3 demonstrates the corroboration of these findings as expressed through the survey responses of licensees, provincial research personnel, and personnel from provincial operations and policy

When presented with the statement, "Researchers should base their goals on the needs of the Partnership members," large differences of opinion emerged. A spread of $37.7 \%$ separates the importance rating of licensees versus provincial rescarchers; $57.1 \%$ of licensees (and $46.7 \%$ of operations and policy respondents) rate this goal as important, whereas only a small minority (19.5\%) of respondents from provincial research rated the goal as important. A majority of respondents from each group support the development of

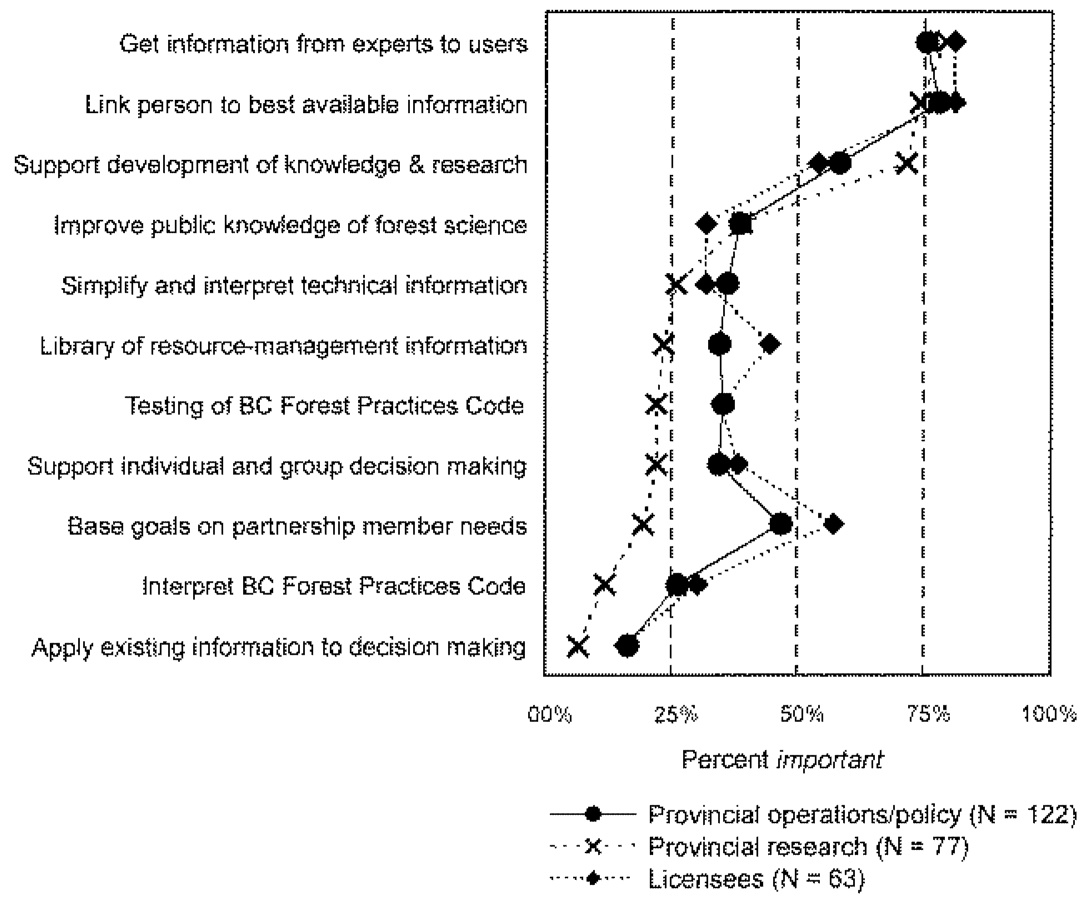

Figure 3.3. Extension goals for three groups. Percent who circled 8,9 , or 10 on a 10 point scale from 1 (very unimportant) to 10 (very important).

Source: Decision Research. Southern Interior Forest Extension Survey (1998). 
knowledge and research as a primary cxtension goal, but a split of $17.5 \%$ separates the higher support offered by provincial research personnel compared to the lower support offered by licensees.

When comparing the between group differences of operations, private consultants, and provincial and federal researchers, some of the above conflicts of interest recur (sce Figure 3.4). Private consultants, versus fcderal and academic researchers, are more supportive of an extension "library," and more likely to press for a Partnership driven research agenda. Private consultants and operations personnel are also more supportive than research personncl of efforts to scientifically test the guidelines put forth in the B.C. Forest Practices Code. Finally, fcderal agency and academic researchers are more likely to support the development of research and knowledge than are consultants or operations/policy personnel. First Nation respondents generally mirror the opinion of other respondents save for a fcw key points: First Nation respondents are more likely, when compared to other Partnership member groups, to support "improved public knowledge of forest science," to support a "library of forest management information," and to recognize the need to "support individual and group decision making."?

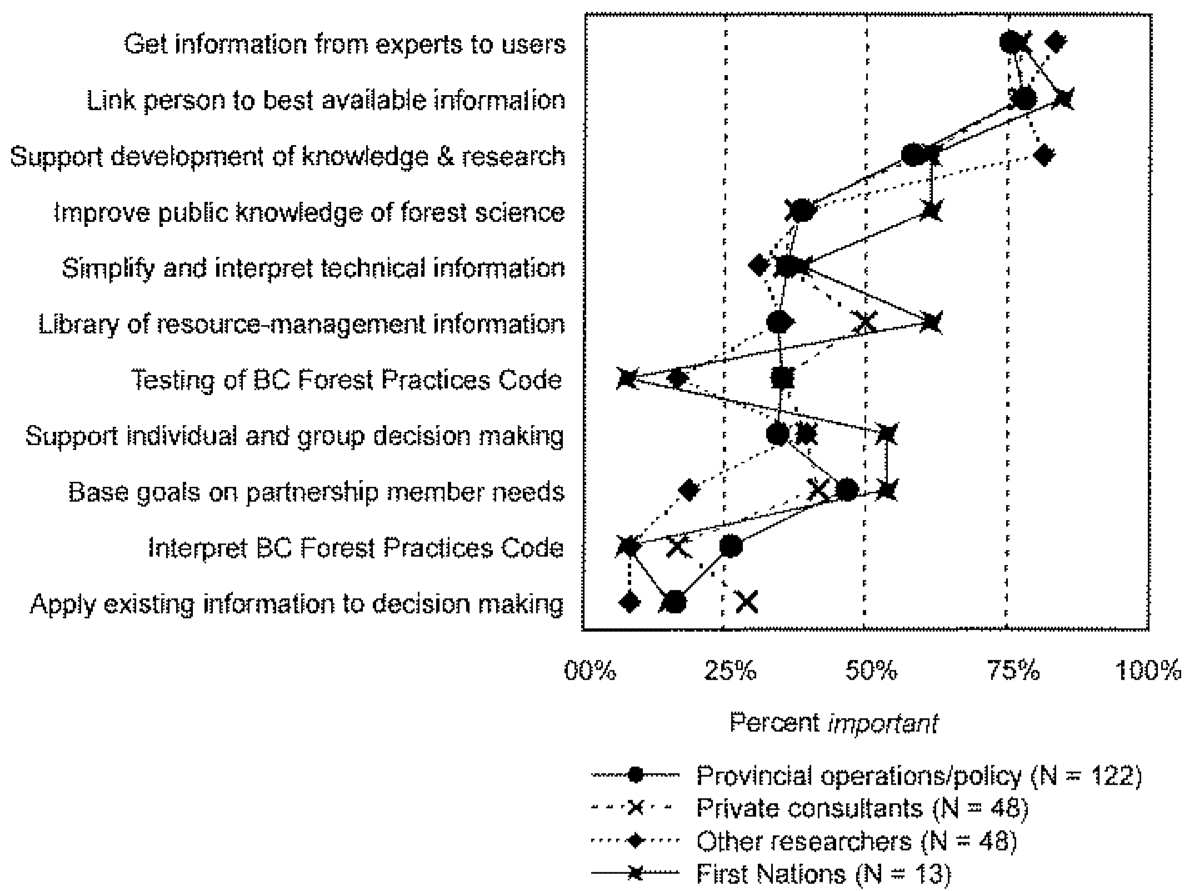

Figure 3.4. Extension goals for three groups. Percent who circled 8,9, or 10 on a fo-point scale from 1 (very unimportant) to 10 (very important).

Source: Decision Research. Southern tnterior Foresi Extension Survey (1998).

${ }^{2}$ Generalizations shond not be drawn on the basis of what is a very small $(N=13)$ First Nation sample. 


\subsection{Regional Differences}

During presurvey focus groups, several participants emphasized regional differences of opinion with regard to basic extension goals. Regional differences emerged between those located in Victoria versus those located in the Southern Interior regions of Kamloops, Nelson and Williams Lake and are depicted in Figure 3.5 below.

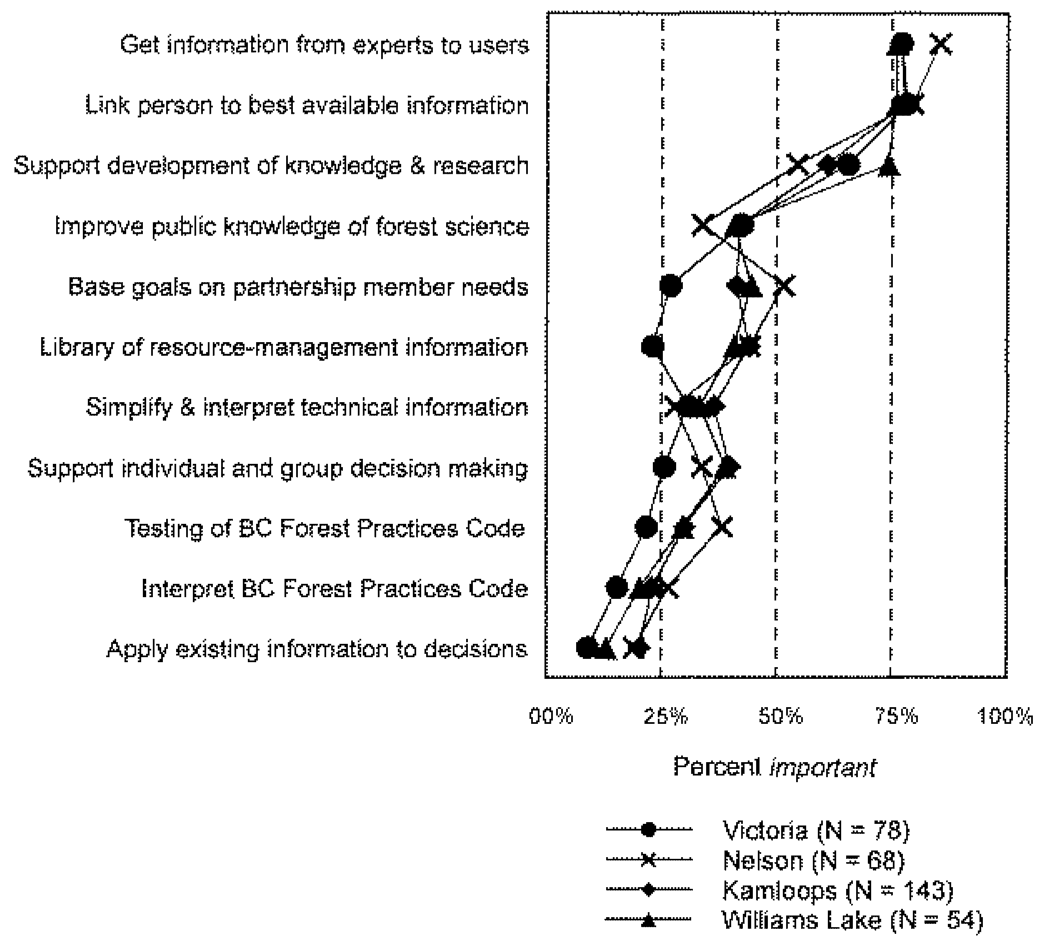

Figure 3.5. Extension goals by region. Percent who clrcled 8,9 , or 10 on a 10-pont scale from 1 (very umimportant) to 10 (very important).

Source: Decision Research, Southern itterior Forest Extension Survey (1998).

Land management stewards in Nclson are much more likely (by nearly $25 \%$ ) to promote an extension service based on the research needs of Partnership members than are those residing in Victoria. ${ }^{3}$ Clients based in all three Southern Interior regions state a need by a magnitude of 17.6 percentage points or greater for a "Iibrary of resource-management information" than do Victoria-based clients. Residents of Nelson are also more likely than Victoria-based land managers to recognize a need to test specific guidelines within the B.C. Forest Practices Code.

Bear in mind that the pattern of difference in this figure is similar to that depicted in figure 3.3 ; it is likely that some of the differences of opinion expressed here are as linked to researcher-operations differences as they are to regional differences. 


\section{4}

\section{Information Needs}

This chapter covers a basic function of extension services: the need to anticipate and understand the types of information that client groups will request. Partnership extension services face a difficult task because both the client groups and the information needs are diverse. As a result, it is essential to understand how the needs of different elient groups vary and to understand the diversity of information categories or types required by these groups to accomplish forest-related activities.

There are, of course, many different ways to organize the multiple categories of information required by Partnership members. The results of extensive discussions on this topic in three focus groups (described earlier) were extremely helpful to the study team in establishing categories of information that were sufficiently detailed to address the management and harvest activities of the different user groups yet general enough to avoid large numbers of categories and thereby induce confusion (e.g., due to potential double-counting) or fatigue among participants. After much discussion, the study team decided to present questions relating to three categories of information, covering (a) habitat, species, and water resources, (b) timber harvest and management, and (c) economic, social, and cultural factors. In addition, separate questions were asked of all Partnership respondents concerning the desired level of support for First Nation efforts to develop improved information

The summary figures shown in this chapter demonstrate responses to questions asking participants about the strength of their expressed needs for each of these information topies. The first three seetions of responses shown below $(4.1,4.2,4.3)$ asked participants to state how frequently they have needed a specified category of information over the past year. Responses were provided using a four-point scale, denoting a Partnership client's need to "never (1), rarely (2), occasionally (3), or often (4)" obtain information on the designated management topic. Section 4.4 provides results of questions asking respondents' level of agreement with extension service support for specified First Nation information needs. 


\section{1 Habitat, Species, and Water Resources}

Figure 4.1 presents the percentage of respondents who "often" or "occasionally" requested information over the past year concerning habitat, species, or water resources.

Over the entire sample, requests for information about riparian management were made

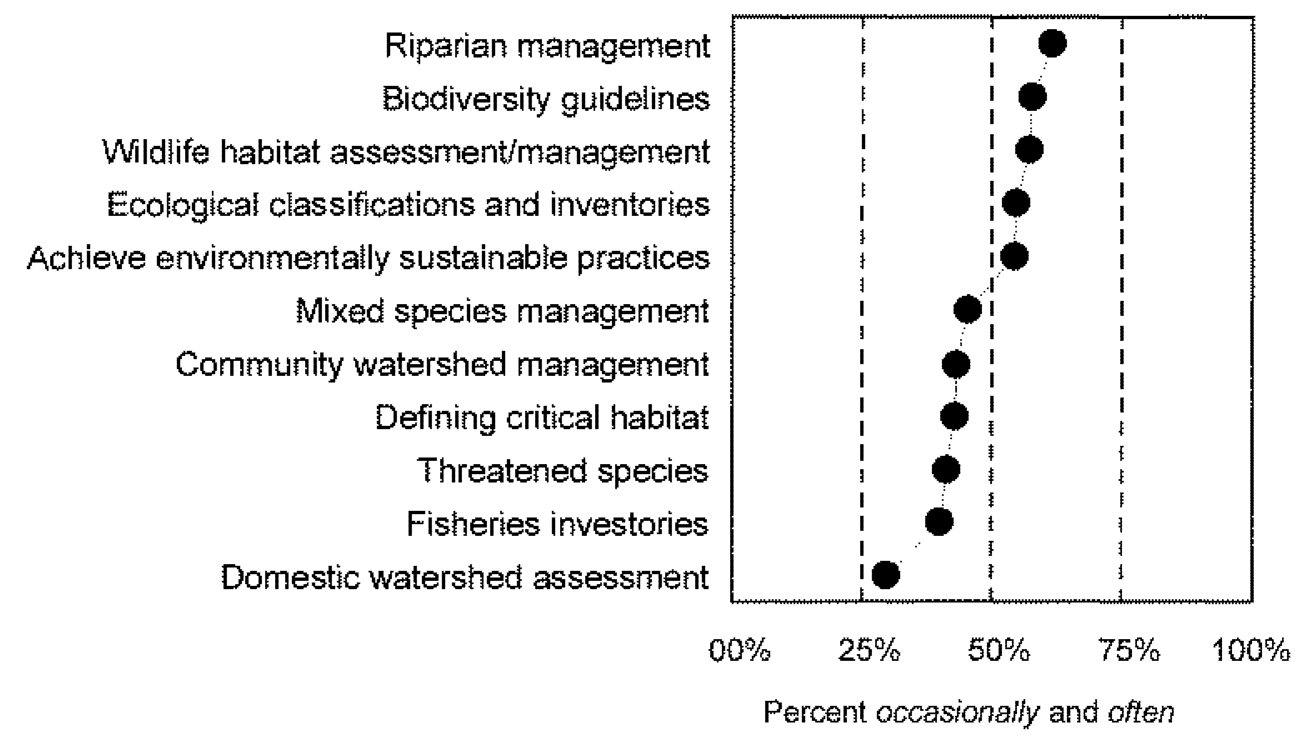

Figure 4-1. Information about habitat, species, or water resources. Percent who circled occasionally or often on a 4-point scale where $1=$ never, $2=$ rarely, $3=$ occasionally, and $4=$ often. $(\mathrm{N}=381)$

Source: Decision Research, Southern Interior Forest Extension Survey (1998).

most frequently (by $61.7 \%$ of participants), followed by information requests about biodiversity guidelines $(57.8 \%)$ and wildlife habitat assessment and management $(57.1 \%)$. Respondents stated that they least frequently requested information about threatened species, fisheries inventories, and domestic watershed assessment. Note that this does not imply that these latter types of information needs are less important overal, but rather that requests for additional information on these topics were made less frequently.

Figure 4.2 considers differences across three key respondent groups: provincial government researchers, provincial government policy and operations personnel, and private-sector licensees. 


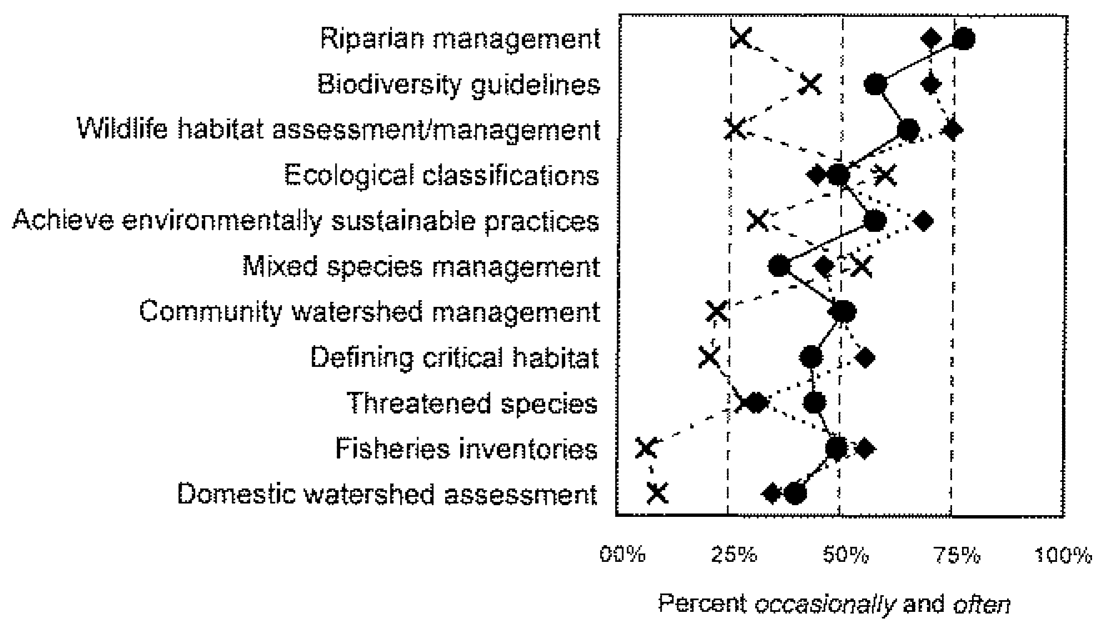

$\longrightarrow$ Provincial operations/pollcy $(\mathrm{N}=122)$
$\ldots+\ldots$ Provincial research $(\mathrm{N}=77)$
$\ldots+\ldots$ Licensees $(\mathrm{N}=63)$

Figure 4.2. Information about habitat, species, or water resources for three groups. Percent for each group who circled occasionally or often on a foutpoint scale where 1 never, $2=$ rarely, $3=$ occasionally, and $4=$ often.

Source: Decision Research, Southern Interiof Forest Extension Survey (1998).

Differences among those participants who "occasionally" and "often" requested information about the designated topics are substantial, although overall the privatem sector licensees responded more similarly to the provincial operations and policy participants than did provincial researchers. For provincial operations/policy participants and for licensees, the most requested categories of information related to concerns about riparian management and wildlife habitat assessment (for both groups) as well as biodiversity guidelines and achieving sustainable practices (for licensees). Provincial government researchers, in contrast, were most concerned with obtaining additional information on ecological classifications and mixed species management; biodiversity guidelines, a priority for all groups, was the third most frequently requested item by provincial government researchers.

Figure 4.3 compares the information requests on habitat, species, and water resources of provincial operations and policy respondents to two other groups: private consultants and other (i.e., university, college, and federal government) researchers. As clearly shown by these results, private consultants (a diverse category of respondents, as described in Chapter 2) are more similar to provincial operations and policy respondents than are 


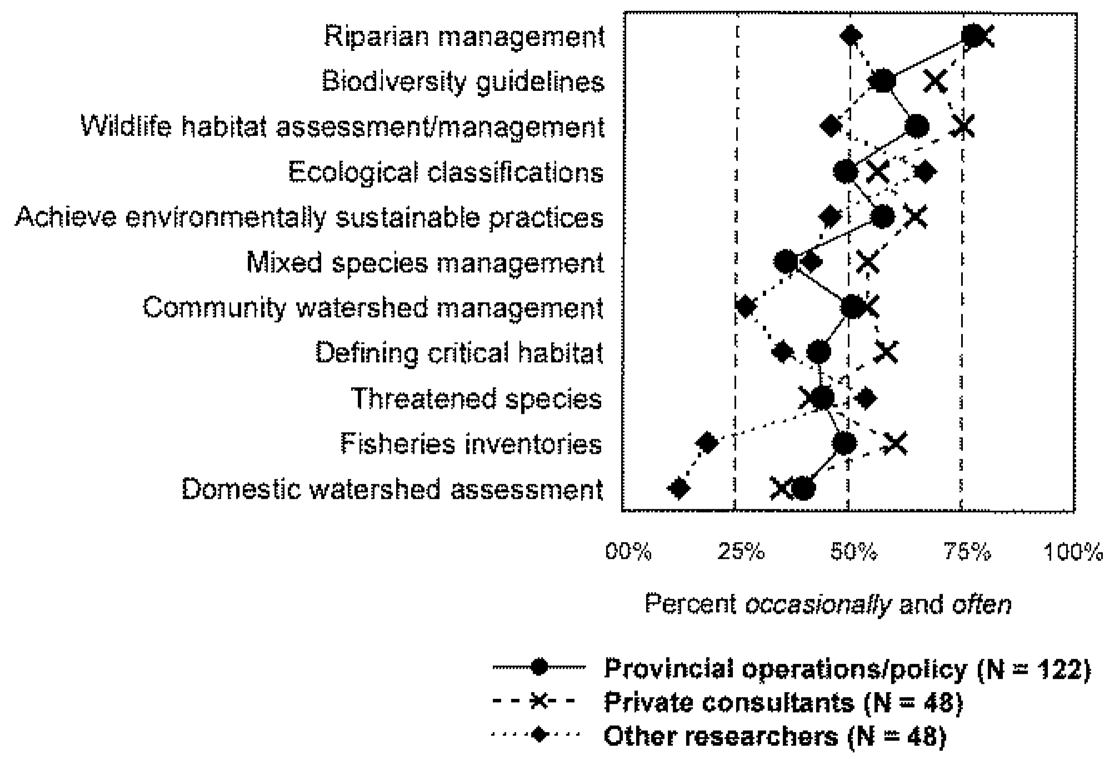

Figure 4.3. Information about habitat, species, of water resources for three groups. Percent for each group who circled occasionally or often on a four-point scale where $1=$ never, $2=$ rarely, $3=$ occasionally, and $4=$ often.

Source: Decision Research, Southern interior Forest Extension Survey (1998).

federal and academic researchers. For the latter category of other researchers, ${ }^{\prime}$ the most frequently requested types of information concern ecological classifications $(66.7 \%)$, biodiversity guidelines $(56.3 \%)$, and threatened species $(54.2 \%)$. These results are quite similar to those reported in Figure 4.2 from the sample of provincial researchers. For provincial operations and policy respondents, the key needs are for information on riparian management $(77.1 \%$ ), wildlife habitat assessment and management $(64.8 \%)$, biodiversity guidelines ( $57.4 \%$ ), and environmentally sustainable forest practices $(56.3 \%)$. For these topics, private consultants' responses are very similar to those of provincial operations/policy participants.

\subsection{Timber Harvest and Management}

Figure 4.4 shows the percent of respondents who "often" or "occasionally" requested information over the past year concerning timber harvest and management. Across the entire sample, requests for information about "legal responsibilities and obligations under the Forest Practices Code" were made most frequently (by $63.4 \%$ of participants),

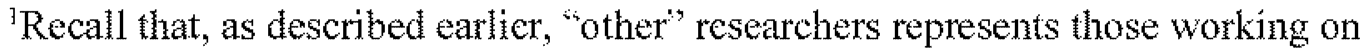
land-management and related topics, but employed by federal agencies and academic institutions. 


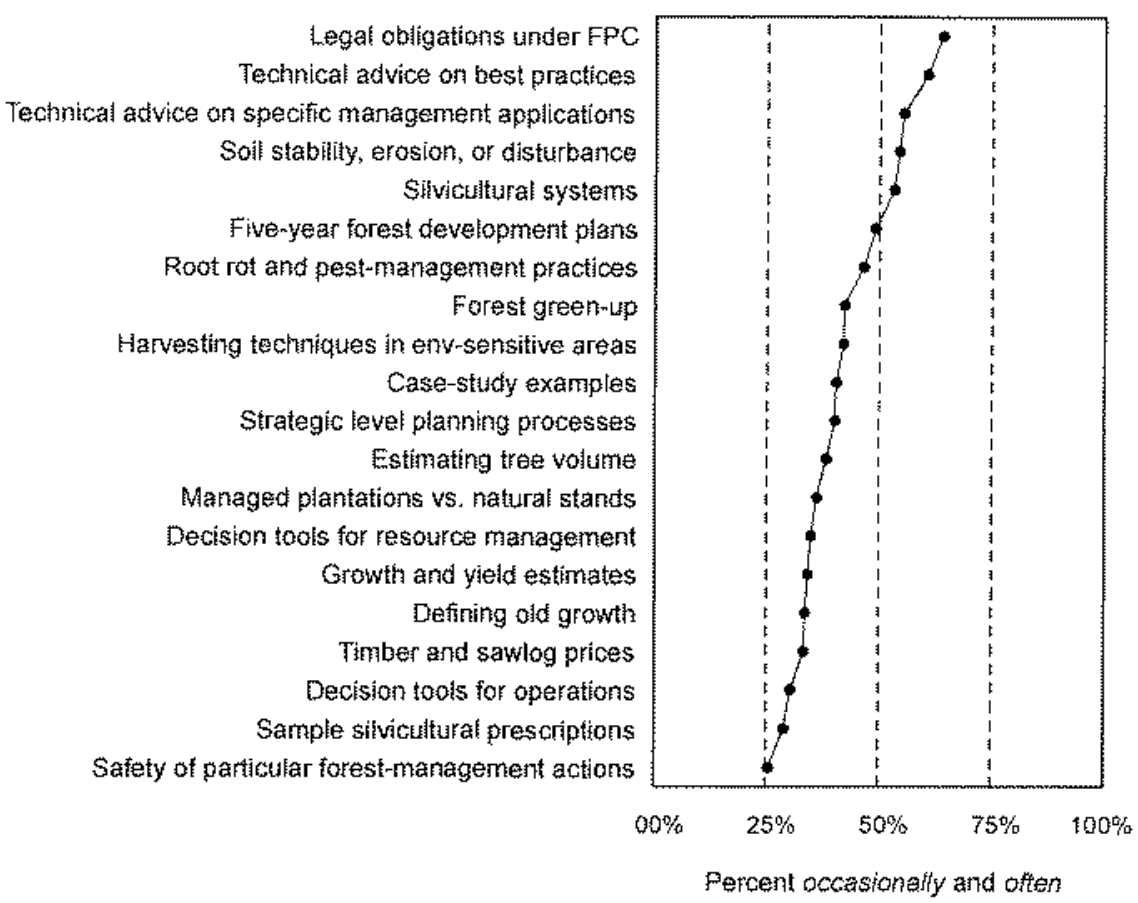

Figure 4.4. Information pertaining to fimber harvest and management. Percent who circled occasionally or often on a four-point scale where $1=$ never, $2=$ rarely, $3=$ occasionally, and $4=$ often. $(\mathrm{N}=381)$

Source: Decision Research. Southem interior Forest Extension Survey (1998).

followed by information requests ahout technical advice on "best practices" and on "specific management applications." Respondents stated that they least frequently requested information about "sample silvicultural prescriptions" or the "safety of particular forestmanagement actions." As in the previous figure, these findings state that requests for additional information on these topics were made less frequently. We do not mean to imply that items toward the bottom of the list in Figure 4.4 are unimportant, rather they should be regarded as needed/required by a smaller proportion of all Partnership clients.

Figures 4.5 and 4.6 present more detailed information concerning differences across the five key respondent groups. Figure 4.5 focuses on provincial government policy and operations personnel, provincial government researchers, and private-sector licensees. Differences among those participants who "occasionally" and "often" requested information about the designated topics arc again large, although in contrast to Figurc 4.2 these differences extend across all three groups: for many categories, the frcquency of the various "timber harvest and management" information requests by provincial operations/policy participants are now quite differcnt from those of private-sector licensees. For provincial government researchers, the most frequent types of harvest and management questions concern silvicultural systems (53.2\%), forest green-up (45.5\%), 


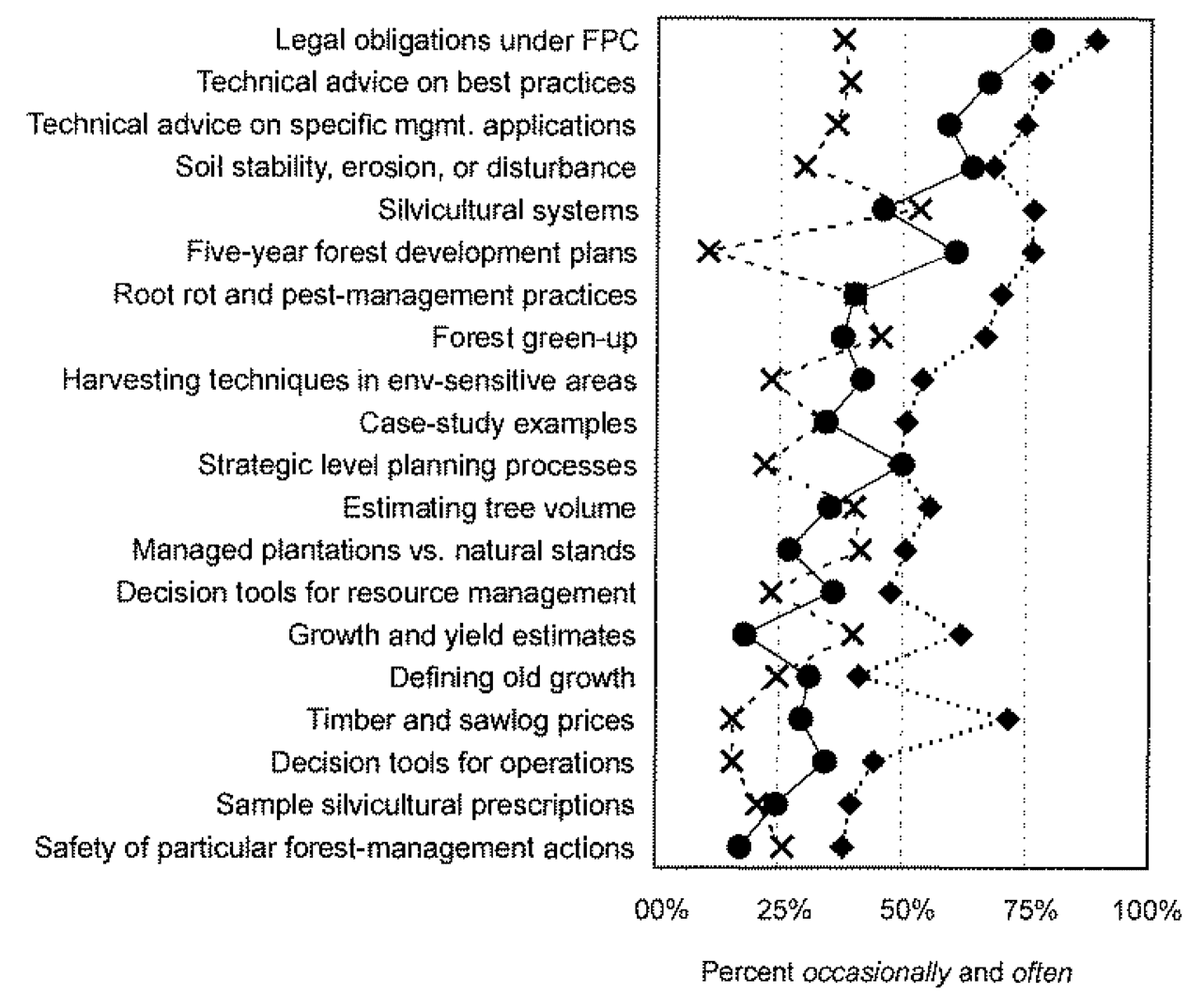

\footnotetext{
- Provincial operations/policy $(N=122)$

- - *- - Provincial research $(\mathrm{N}=77)$

$\cdots+\cdots$ Licensees $(\mathbf{N}=63)$
}

Figure 4.5. Information pertaining to timber harvest and management for three groups. Percent in each group who circled occasionally or often on a four-point scale where $1=$ never, $2=$ rarely, $3=$ occasionally, and $4=$ often.

Source: Decision Research, Southern Interior Forest Extension Survey (1998).

and differences between managed plantations and natural stands (41.6\%). For privatesector licensees, information concerning their legal obligations under the Forest Practices Code $(88.9 \%)$ and technical advice on best practices $(77.8 \%)$ are most often requested. Provincial government operations and policy personnel also gave high ratings to requests for information about their legal responsibilities under the Code (77.9\%), as well as to technical advice on best practices $(67.2 \%)$ and information on soil stability, erosion. or disturbance $(64.0 \%)$. Although the overall pattern of requests for licensees and provincial operations/policy personnel is similar, the frequency of requests made "occasionally" and "often" by provincial government employees tends to be far lower.

Figure 4.6 compares the "timber harvest and management" information requests of provincial operations and poltcy respondents to private consultants and to other researchers. The pattem of responses shown by private consultants closely mirrors that of 


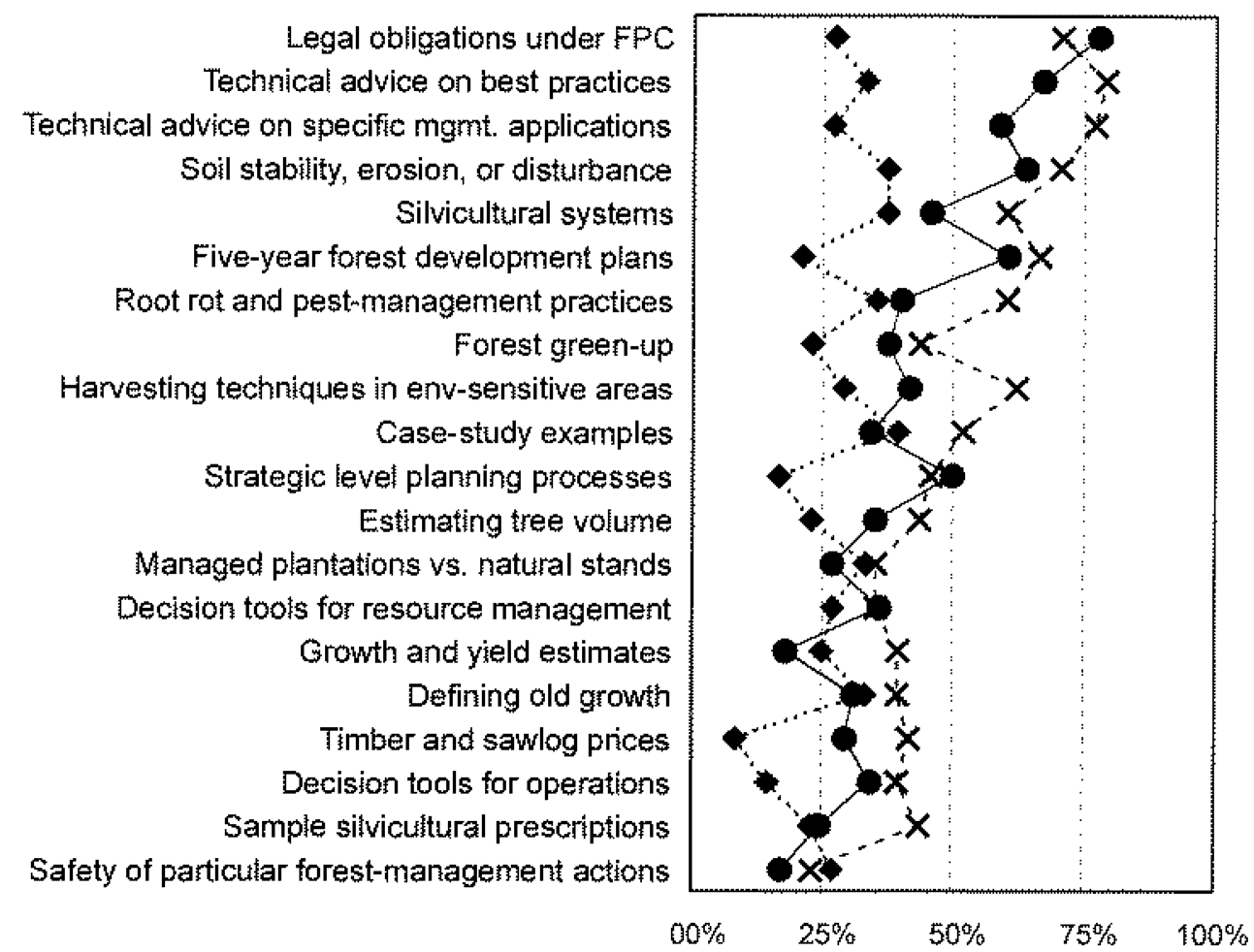

Percent occasionally and often

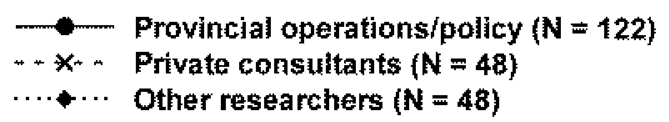

Figure 4.6. Information pertaining to timber harvest and management for three groups. Percent in each group who circled occasionally or often on a four-point scale where $1=$ never, $2=$ rarely, $3=$ occasionally, and $4=$ often.

Source: Decision Research, Southern Interior Forest Extension Survey (1998).

provincial operations/policy personnel, with some minor (but expected) differences; for example, technical advice on specific management applications, on root-rot and pestmanagement practices, and on harvesting in environmentally sensitive areas is requested more frequently by private consultants. Respondents in the category of other researchers are particularly in need of information on case-study examples, on silvicultural systems, soil stability, and on managed plantations vs. natural stands. Overall, the pattern of responses by this group of academic and federal researchers is again quite similar to that shown by provincial research respondents.

\subsection{Economic, Social, and Cultural Factors}

Figure 4.7 presents the percent of respondents who "often" or " occasionally" requested information over the past year concerning economic, social, or cultural factors. Over the 


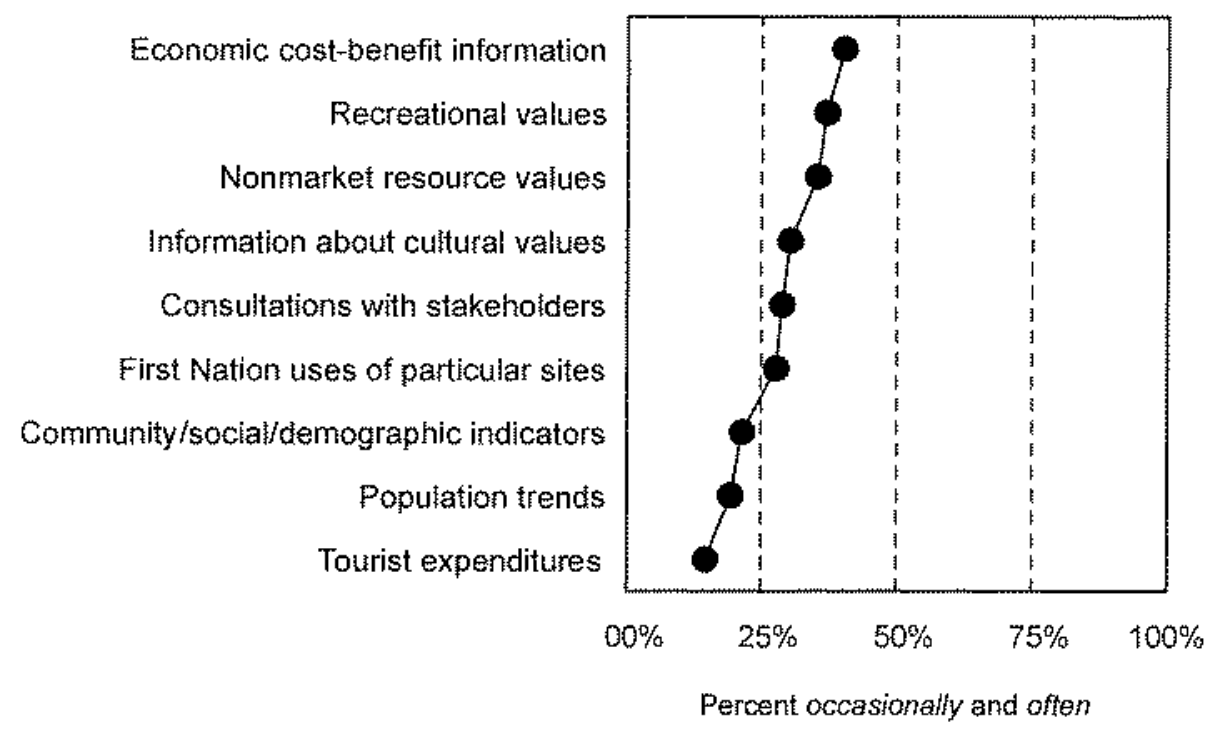

Figure 4.7. Information about econornic, social, or cultural factors. Percent who circled occasionally or often on a four-point scale where $1=$ never, $2=$ rarely, $3=$ occasionally, and $4=$ often. $(\mathrm{N}=381)$

Source: Decision Research, Southern Interior Forest Extension Survey (1998).

entire sample, requests for economic cost-benefit information were made most frequently (by $38.0 \%$ of participants), followed by information requests about recreational values (35.2\%) and about nonmarket resource values (33.0\%). Information about the cultural value of forest resources also was frequently requested. Respondents stated that they least frequently requested information about population trends or tourist expenditures; it is likely that good quality information about thesc topics is readily available in provincial government documents.

Figure 4.8 considers differences across provincial government researchers, provincial government policy and operations personnel, and private-sector licensees. Licensees were most concerned about obtaining information on the economic costs and benefits of forest rcsources; questions conccrning nonmarket resource values and cultural values also rated highly. Provincial government operations and policy personnel, in contrast, were most concerned with obtaining additional information on recreational values, followed by consultations with stakcholders and First Nation uses of particular sites. Provincial government researchers also rated economic cost-benefit information as their most important necd, followed by nonmarket resource valucs.

Figure 4.9 compares responses concerning the economic, social, and cultural information needs of private consultants and other researchers to those of provincial operations/policy participants. The general pattern of responses for all three groups is quite similar, 
Economic cost-benefit information

Recreational values

Nonmarket fesource values Information about cutturat values

Consultations with stakeholders

First Nation uses of particular sites

Community/socialdemographic indicators

Population trends

Tourist expenditures

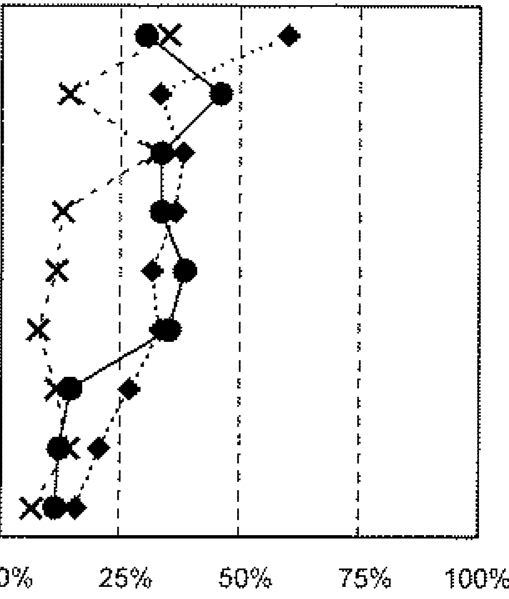

Percent occastonally and often

- Provincial operations/policy (N $=122)$ $\cdots *$ Licensees $(N=63)$

Figure 4.8. Information about economic, social, or cuturat factors tor three groups. Percent who circled occasionally or offen on a four-point scale where 1 never, 2 = rarely, $3=$ occasionally, and $4=$ often.

Source: Decision Research, Southern Interior Forest Extension Suvey (1998),

Economic cost-benefit information

Recreational values

Nommarket resource values

Information about cultural values

Consultations with stakeholders

First Nation uses of particular sites

Community/sociat/demographic indicators

Population trends

Tourist expenditures

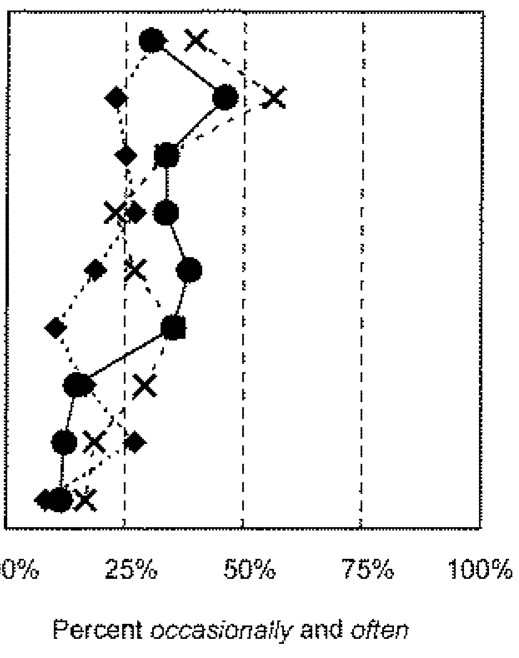

- Provincial operations/policy ( $N=122)$

- $\times$ - Private consultants $(N=48)$

…... Other researchers $(\mathrm{N}=48)$

Figure 4.9. Information about economic, social, or cuftural factors for three groups. Percent who circled occasionally of often on a four-point scale where $1=$ never, $2=$ rarely, $3=$ occasionally, and $4=$ often.

Source: Decision Research. Southern Interior Forest Extension Survey (1998). 
although differences in the frequency of requests for several specific information categorics are striking: for example, note the requests by private consultants for information on recreational values, and the absence of a need by federal and academic researchers for information on First Nation uses of sites.

\subsection{Support for First Nation Information Needs}

This section of questions asked Partnership clients (most of whom are nonaboriginal) to state their level of support for efforts by First Nations to develop improved access to certain categories of information and technology. Responses were provided using a fourpoint agree-disagree scale, with options from "strongly disagree" to "strongly agree"; a fifth, "don"t know" option also was provided. ${ }^{2}$

As shown in Figure 4.10, support was highest for supporting First Nation efforts to develop additional information relating to sustainable nontimber forest uses; over threem quarters of those questioned $(76.6 \%)$ agreed that this was a high priority. High levels of support also were shown for sustainable timber practice case studies $(73.2 \%)$, improved records (oral histories, archeological remains, etc) of aboriginal resource uses, and animal

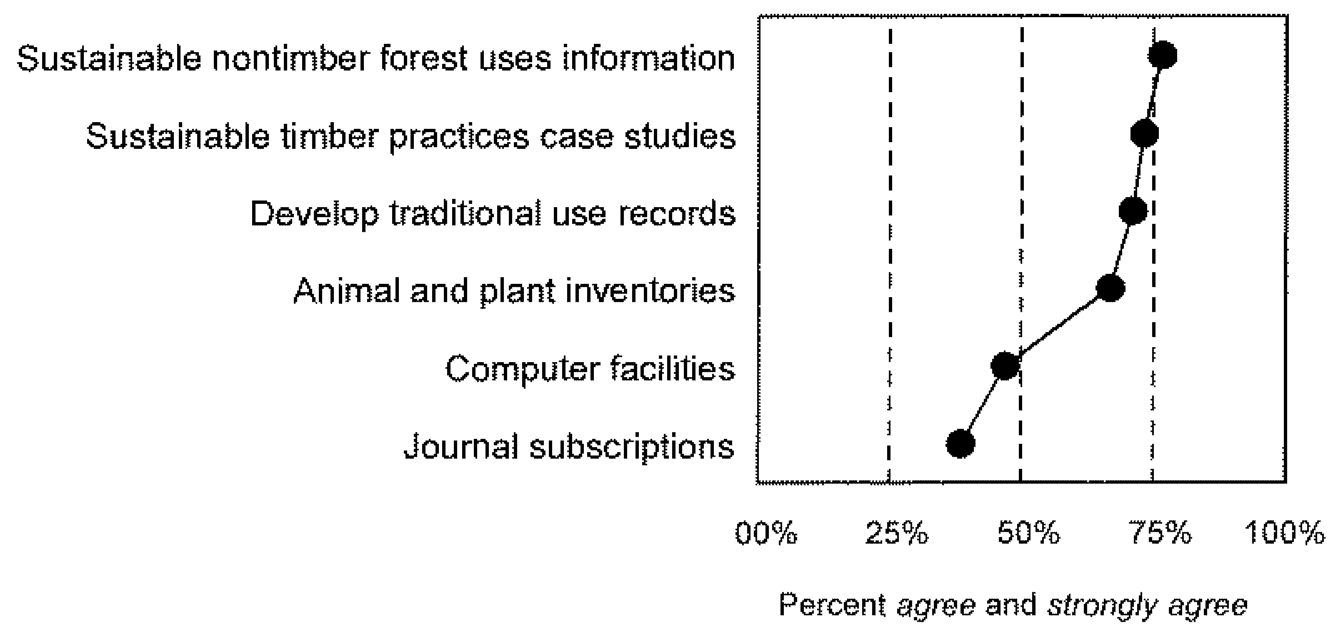

Figure 4.10. First Nation information needs. Percent who circled agree or strongly agree on a four-point scale where $1=$ strongly disagree, $2=$ disagree, $3=$ strongly agree, and 4 = agree. $(\mathrm{N}=381)$

Source: Decision Research, Southern Interior Forest Extension Survey (1998).

${ }^{2}$ As noted earlier. First Nation information needs will be addressed in future follow-up work. We consider this work a frrstmorder priority; discussions are underway to coordinate that effort and to design a survey protocol that is specific to First Nations: capacity to contribute to and benefit from the Southern lnterior Partnership. 


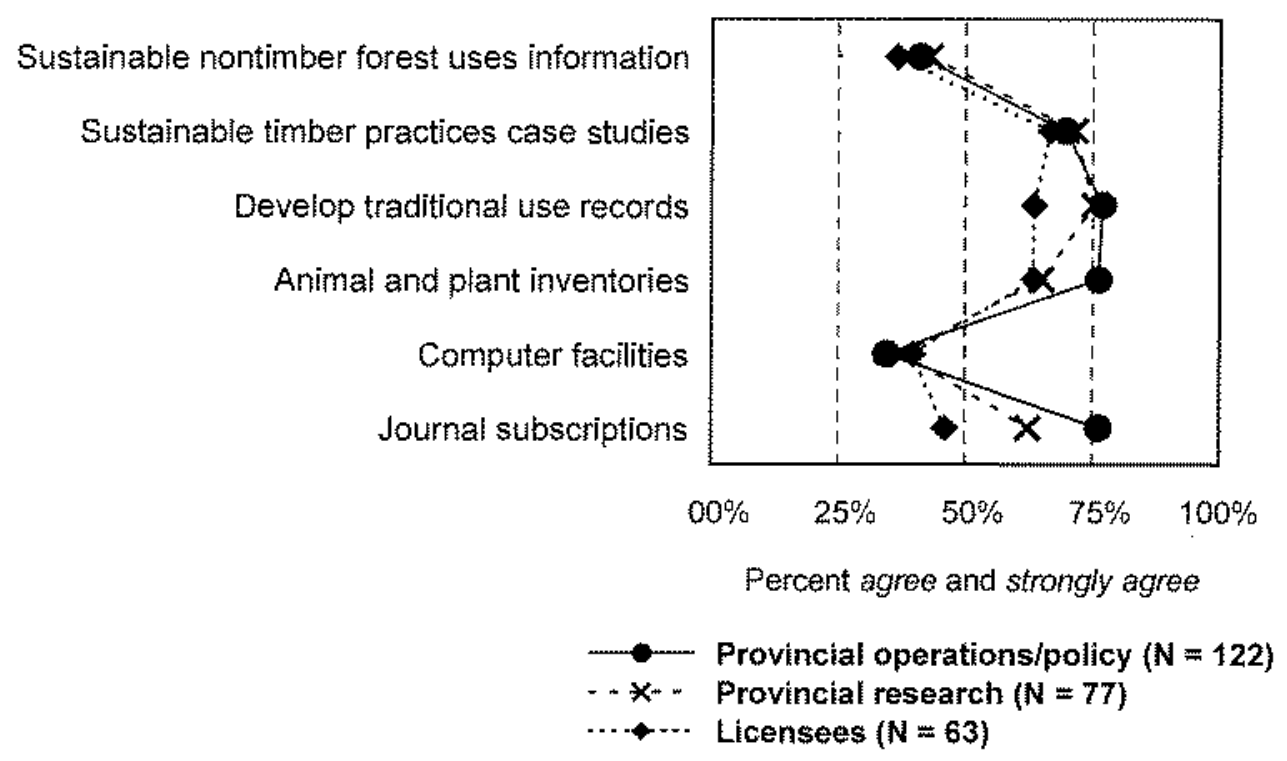

Figure 4-11. First Nation information needs for three groups. Percent who circled agree or strongly agree on a four-point scale where $1=$ strongly disagree, $2=$ disagree, $3=$ strongly agree, and $4=$ agree.

Source: Decision Research, Southern Interior Forest Extension Survey (1998).

and plant inventories (66.9\%). Sharply lower rates of support were shown for improvements in computer facilities (as a means for accessing information) and for journal subscriptions.

Details by group are shown in Figures 4.11 and 4.12. The overall patterns of responses shown in Figure 4.11 are quite similar among provincial operations/policy participants, provincial government researchers, and licensees, although the level of support for assisting First Nations to develop their information base and processing capabilities is higher among provincial operations/policy personnel and researchers than among licensees. Differences across respondent groups are more obvious in Figure 4.12, with private consultants showing relatively low levels of support for improvements in First Nations" access to journal subseriptions (33\%) but high levels of support for information on sustainable nontimber forest uses (77\%) and sustainable practices case studies $(73 \%)$. Provincial operations/policy respondents, on the other hand, showed low support for these information categories and relatively higher levels of agreement with support for development of traditional use information and improved animal/plant inventories. Academic and federal government researchers agreed on the importance of developing First Nations' information on sustainable nontimber forest uses and sustainable practices case studies, with inventory information also considered important by over three quarters of respondents. 
Sustainable nontimber forest uses information

Sustainable timber practices case studies

Develop traditional use records

Animal and plant inventories

Computer facilities

Joumal subscriptions

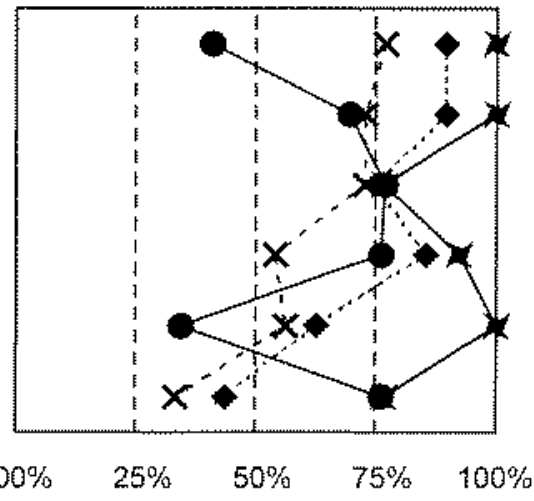

Percent agree and strongfy agree

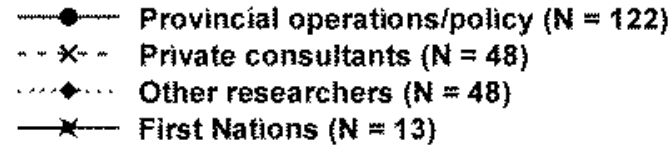

Figure 4-12. First Nation information and technology needs as identified by four groups. Percent who circled agree or strongly agree on a four-point scale where 1 = strongly disagree, 2 = disagree, $3=$ strongly agree, and $4=$ agree.

Source: Decision Research, Southern Interior Forest Extension Survey (1998).

Notably, First Nation respondents were uniform in their strong support (100\% "agree" and "strongly agree"), relative to all other subgroups, for information about sustainable nontimber forest uses, and sustainable timber-practice case studies. First Nation respondents also expressed a strong need for computer facilities and plant and animal inventories. 


\section{5}

\section{Communication}

Sound land use planning depends on the success with which forest management specialists, employees and managers can converse and mutually avail themselves of necessary knowledge and information. Effective communication will ensure that the best available knowledge about forest management move quickly to application. Several questions concemed with ease of communication wcre addressed directly by the Partnership Client Needs survey: Can those who might apply new management technologies access the learning opportunities necessary to bring that knowledge to use? Is the relationship sound between those who conduct basic and applied forest research and those who use the products of that research? Does information come in a form that is viable for those who might use it? Docs the Partnership recognize the concerns of all its constitucnt groups? Three sets of questions explored, respectively, the accessibility and availability of information about forest management, the linkages between operations and research branches within the Partnership, and the responsiveness of the Partnership to First Nation concerns about traditional uses and management within forest ecosystems.

\subsection{Availability and Accessibility of Information}

Five survey questions were employed to monitor Partnership members' overall assessment of both the availability and accessibility of information. An analysis across partnership groups reveals large differences. These differences are most striking when comparing the opinion of research branch respondents to private sector consultants, licensees, and respondents from the operations and policy branches of the provincial government's land management agencies.

Figure 5.1 depicts the variance on items by calculating between-group difference scores. The column of numbers just inside the left-hand side of Figure 5.1 represents the percentage of provincial research employees who either agreed or strongly agreed with the five availability and acceptability statements. The comparative line graphs to the right represent the difference scores (either negative or positive) for each item across each of 
the three groups. ${ }^{1}$ Thus, if the graph depicts a score of $-22 \%$ for operations and policy, it should be read as operations and policy branch respondents being less likely than research branch respondents to agree with that item by a margin of 22 percentage points.

One point emerges as crucial above all others in this figure. When compared to the provincial research community, respondents across all three groups are much more likely to agree with the first statement: 1 don't know how to determine what information is already available on a topic. One might expect researchers to be adept at identifying necessary information. Regardless, it is a fault of current services that so many of those

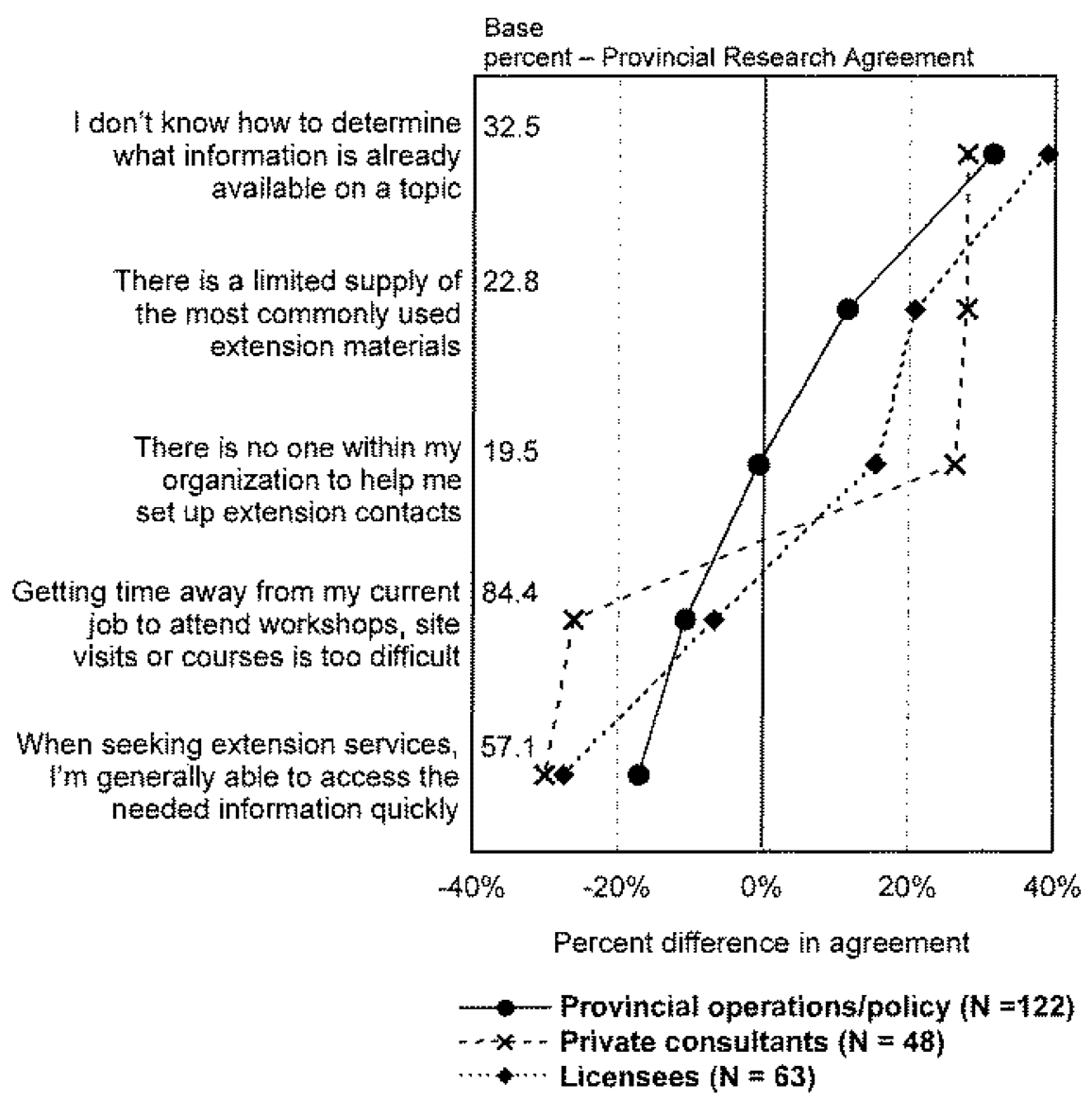

Figure 5.1. Availability/access to information for three groups. Base percent equals provincial research agreement. Percent difference is percentage of agree or strongly agree responses for each group on each item, minus the provincial research agreement response.

Source: Decision Research, Southern Interior Forest Extension Survey (1998).

There are four groups represented in this figure if you include the baseline scores for research branch personnel. 
who might apply the products of researehers cannot locate those products when needed. Moreover, if the provincial research branch assumes that information is readily available, there is then little motivation to seek efficacious alternatives for the dissemination to users of new knowlcdge. Also noteworthy in this figure is the finding that both liccnsees and private consultants are (by a margin of $21 \%$ and $28 \%$, respectively) morc likely to find that there is a limited supply of the most commonly uscd extension materials, and that these same two groups (liccnsecs and privatc consultants) lack the support necessary within their organizations to establish extension contaets.

\subsection{Research/Operations Linkages}

If one aim of extension services is to faeilitate a productive dialogue between rescarch and operations personnel (for both private and public sector operations), then the survey results disclose solid support for the efforts of the provincial public-sector research community. However, survey respondents cxprcssed some discontent about the lack of cross-fertilization of ideas across both research and operations and also noted concerns regarding the length of time required to move ideas from fruition to application.

Figure 5.2 (on the following page) demonstrates that a majority of respondents are favorably impressed by the skills of information providers in that $64 \%$ agree or strongly agrce that the persons they call upon to provide information are very knowledgeable. Widespread support for the timc and energy invested in research projects that may evolve over several years is also evident in that only one-third of respondents $(31.9 \%)$ agree with the statement: the research community does too much long-term research and not enough to address short term problems.

A large majority of respondents $(64.0 \%)$ believe that it is difficult to find who the knowledgeable person is on a topic. Ncarly two-thirds of respondents $(68.2 \%)$ believe that "researchers should be more forthcoming with preliminary results whon field workers need help." Slightly over one-third of respondents (34.9\%) find that "the research commuxity responds sufficicntly to the questions generated by users when setting research priorities." Finally, less than one-fourth of respondents (24.1\%) regard the research community as attentive to different cultures and learning styles. These results suggest that important, unresolved conmunication issues remain between those who develop knowledge (the provineial research community) and those who put that knowlcdge into action. 


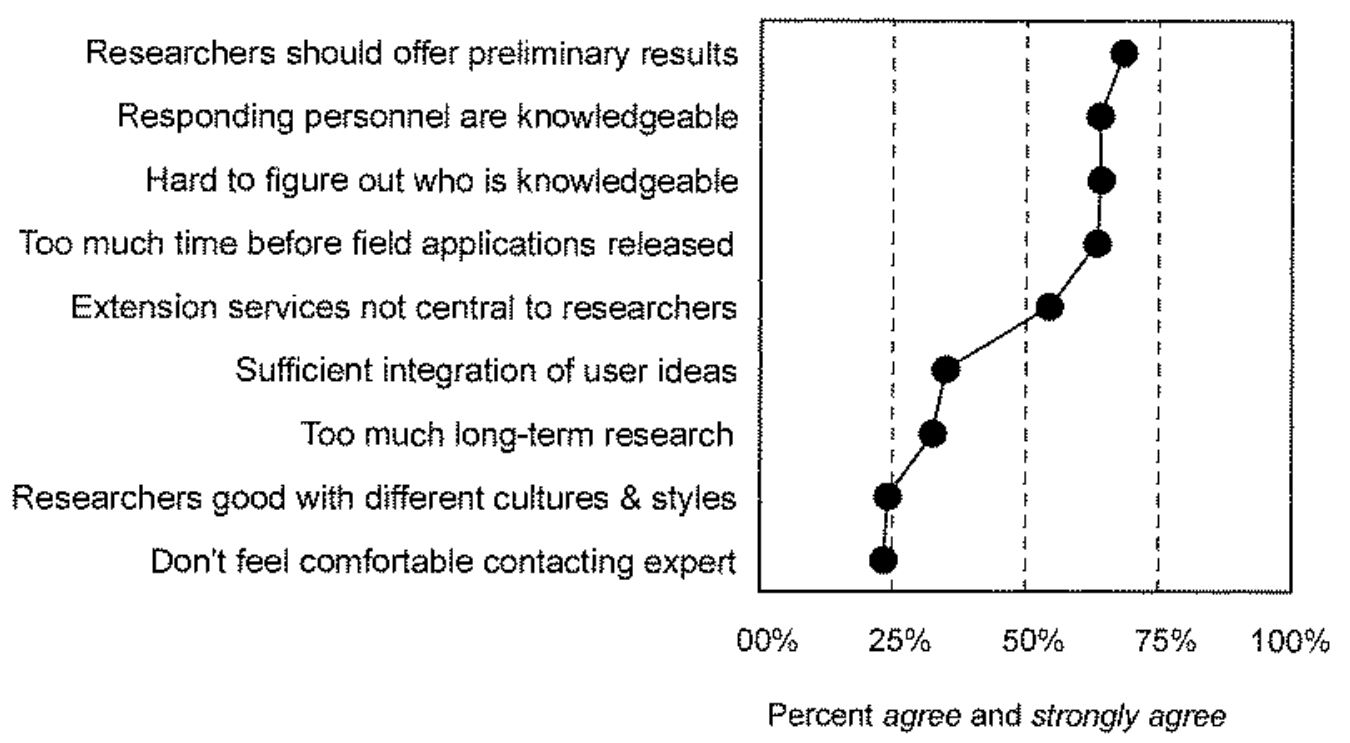

Figure 5.2. Research/operation linkages. Percent who circled agree or strongly agree on a four-point scale where $1=$ strongly disagree, $2=$ disagree, $3=$ strongly agree, and $4=$ agree. $(\mathrm{N}=381)$

Source: Decision Research, Southern Interior Forest Extension Survey (1998).

Figure 5.3 (on the following page) portrays the samc "operation-research linkages" question set, but explores the attitudinal differences between licensees, provincial researchers, and respondents from the MOF, MELP and Ministry of Agriculture operations and policy branches. The greatest differences of opinion arise when consider ing the cross-fertilization of ideas, the appropriateness of long-term research, and the identification of target information providers.

Specifically, respondents from the provincial research sector arc much more likely (by a margin of $21 \%$ ) than their operations and licensee colleagues to agree that "researchers respond sufficiently to the questions generated by users." [Note, however, that fewer than $50 \%$ of all provincial researchers believe that the integration of ideas is sufficient, so none of the three groups express a majority of support for this item.] Researchers are also less likely to believe (by a margin of $25 \%$ ) that there is an overemphasis on long-term research problems at the expense of short-term ones when compared to lieensees. Licensees are much more likely to express difficulty with identifying "who the knowledgeable person is on a [given] topie" than are researchers and, to a lesser degree, than are operations personnel. Finally, all three groups believe that researchers need to be "more forthcoming with preliminary results when field workers need help." 


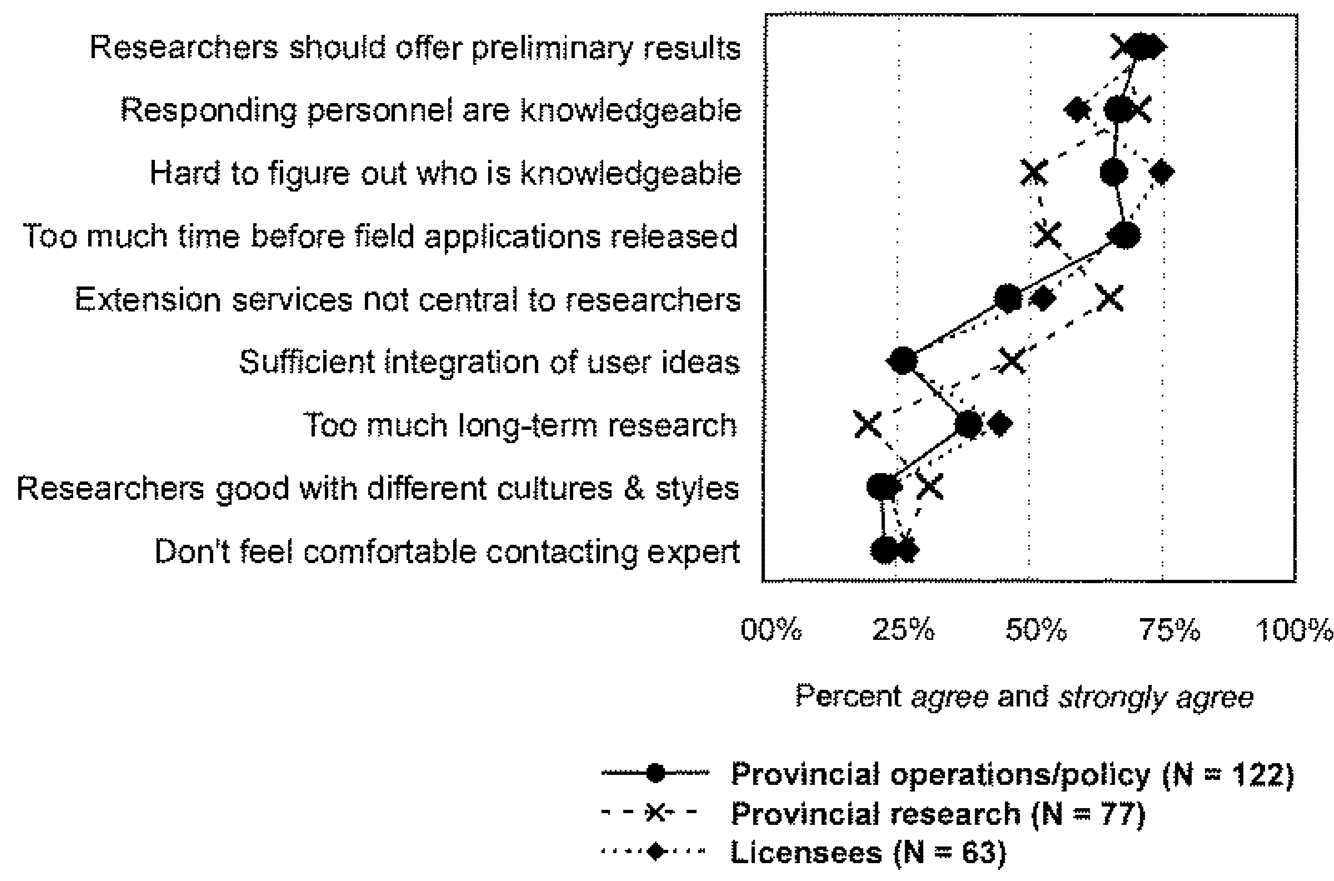

Figure 5.3. Research/operation linkages for three groups. Percent who circled agree or strongly agree on a four-point scale where $1=$ strongly disagree, $2=$ disagree, $3=$ strongly agree, and $4=$ agree.

Source: Decision Research, Southern Interior Forest Extension Survey (1998).

Federal agency and university/college researchers replicate the above pattcrn for provincial researchers in that $54.2 \%$ (this time a slim majority) believe that the integration of user ideas is sufficient as compared to only $26.2 \%$ of operations and policy personnel and $37.5 \%$ of private consultants. Also, only $6.25 \%$ of federal and university researchers, as compared to $43.6 \%$ of consultants and $38.5 \%$ of provincial operations and policy, agree that an over-emphasis on long-term research presents a problem for shortterm problem solving (see Figure 5.4).

The survey was also concened with communication between provincial government branches and First Nation groups responsible for land management. Good communication between these parties will depend to some degree on the extent to which information providers recognize First Nation extension needs and also recognize the validity of knowledge bases that differ methodologically and theoretically from mainstream science. Three of the survey questions address First Nation concerns about the validity of traditional knowledge and the pertinence of the Delgamulk ruling ${ }^{2}$ for extension services.

2 In the 1997 Delgamuuk ruling, a new trial over aboriginal title to traditional lands was ordered. The riling is nonetheless regarded by many First Nation peoples as significant because it recognizes the importance of oral history or traditional knowledge and broadens the definition 


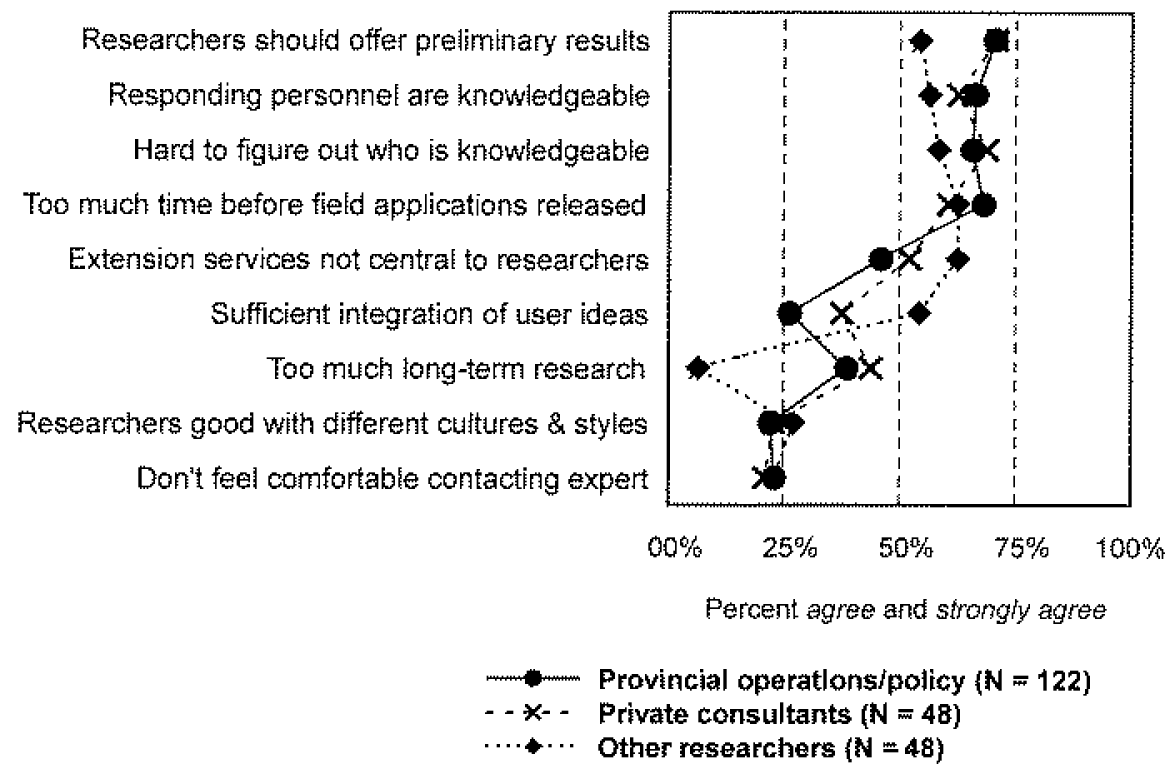

Figure 5.4. Research/operation linkages for three groups. Percent who circled agree or strongly agree on a four-point scale where $1=$ strongly disagree, $2=$ disagree, $3=$ strongly agree, and $4=$ agree.

Source: Decision Research, Southern Interior Forest Extension Survey (1998).

These question items are as follows; respondents were asked to rate each using a fourpoint agree/disagree scale. ${ }^{3}$

\footnotetext{
- First Nation knowledge about traditional land-management practices should be given equivalent status when compared to scientific information.

- Generally speaking, First Nation groups should not discuss traditional use knowledge with non-Native Partnership members.

- The recent "Delgamuuk" decision in the federal courts increases the demand for extension services speciffc to the needs of First Nation groups.
}

of aboriginal title (Vancouver Sin, August 29, 1998, A17). Many expect that in time a greater responsibility for land management will shift to First Nation groups and this extension-style communication between First Nations and the provincial agencies will increase.

${ }^{3}$ Once again, question items were drawn directly from small group and focus group interviews; a focus group specific to First Nation concerns was convened during the pre-survey design period. 
Figures 5.5 and 5.6 depict the responses across all five groups for this question set, with operations and policy respondents constant to both figures.

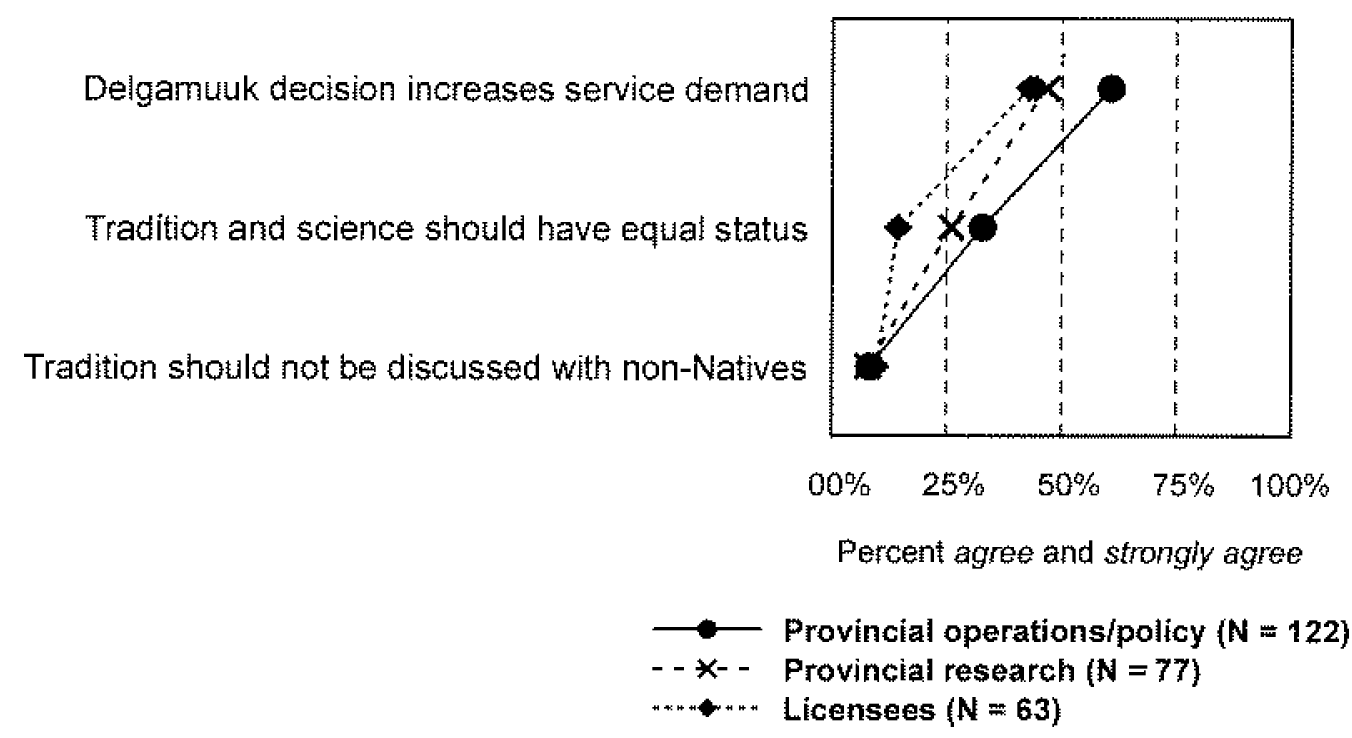

Figure 5.5. First Nation/provincial agency linkages for three groups. Percent who circled agree or strongly agree on a four-point scale where $1=$ strongly disagree, 2 = disagree, $3=$ strongly agree, and $4=$ agree.

Source: Decision Research, Southern Interior Forest Extension Survey (1998).

All First Nation respondents (100\%) as well as a majority of policy operations personnel $(60.6 \%)$, university and foderal researchers $(60.4 \%)$, and private consultants $(58.3 \%)$ recognize the Delgamuuk ruling as having inereased the demand among First Nation groups for extension services. At the same time, slightly fewer than half of all provincial government researchers $(46.8 \%)$ and licensees $(42.9 \%$ ) recognize an increased postDelgamulk need for extension services among First Nation groups.

Presurvey focus-group findings indicated some tension between First Nation and nonFirst Nation peoples about the [occasional] necessity for First Nation groups to privacy regarding traditional knowledge. Several of the First Nation coordinators (during presurvey interviews), working as liaisons between Ministry of Forests and several Southern Interior band councils, also criticized provincial forest-sector employees for failing to grant equal status to traditional knowledge. Consistently, survey results show that very few ( $12.5 \%$ or less) of non Aboriginal respondents and $30.8 \%$ of Aboriginal respondents support the idea that Native people should not discuss traditional use knowledge with non Natives. Survey responses demonstrate that less than one-third of any of the five 


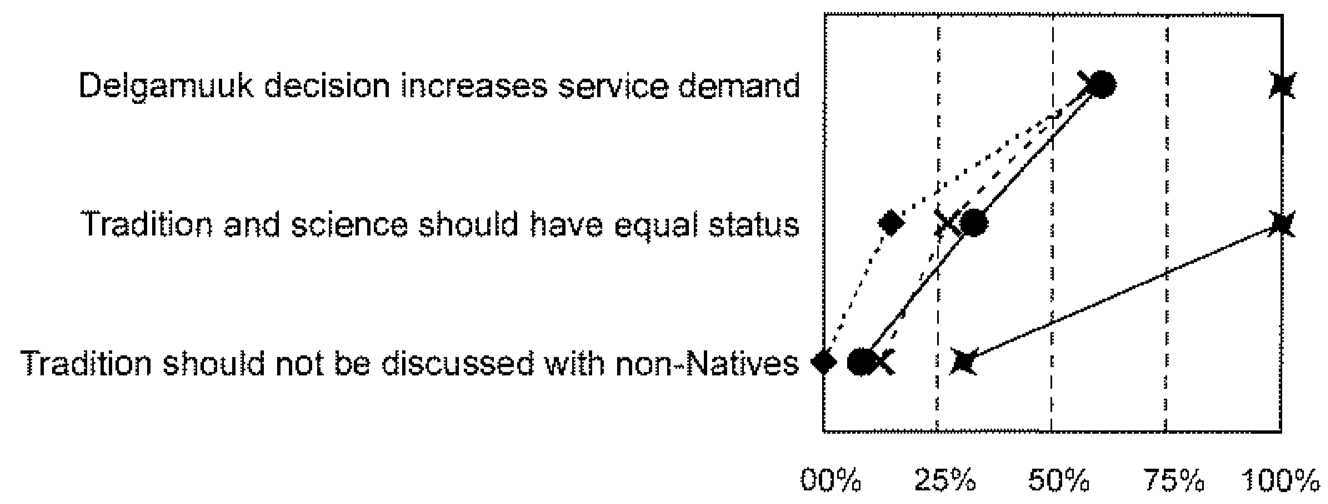

Percent agree and strongly agree

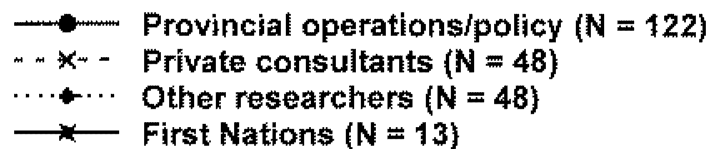

Figure 5.6. First Nation/provincial agency linkages for four groups. Percent who circled agree or strongly agree on a four-point scale where $1=$ strongly disagree, 2 = disagree, 3 = strongly agree, and $4=$ agree.

Source: Decision Research, Southern Interior Forest Extension Survey (1998).

subsamples included in the figure agree that traditional land-management practices should be given equivalent status when compared to scientific information. This opinion is challenged by the full support (100\%) First Nation respondents grant "traditional knowledge of land-management practices." 


\section{6}

\section{Quality of Information}

The perceived quality of information provided to Partnership clients is an important consideration when thinking about changes to the existing extension service. Although quality has many aspects, the study team focused on two dimensions that werc repeatedly discussed in focus groups and in interviews with Partnership members: the format by which information is provided and the level of trust in the information source

\section{1 Presentation of Information}

Several different questions, located throughout the survey, asked participants to express their opinion about aspects of the format and presentation of information. These questions used a four-point scale, showing responses ranging from "strongly disagree" to "strongly agree," including a fifth "don't know" option that was provided for participants.

Responses are summarized in Figure 6.1, which shows the percentage of respondents who agreed or strongly agreed with each of eight separate questions concerning the quality of information provided for them through various aspects of the Parnership. The first line ("research is applicable to needs") shows that just under one-half of participants (48.3\%) agreed or strongly agreed that "members of the Scientific Community conduct work that directly addresses the information needs of the forest community," and a somewhat smaller percentage ( $42.8 \%$ ) agreed that the information provided by current extension services is generally "in a form that is clear and easy to follow." About the same percentage of respondents agreed that the research community "understands the questions and issues important to operators" ( $40.2 \%$, shown in line 4$)$. These relatively low pcrcentage results (i.e., substantially less than $50 \%$ ) suggest a significant gap between the perceived agenda of the research community and the expresscd needs of Partncrship members.

Several of the questions shown in Figure 6.1 were asked as questions of dissatisfaction rather than of satisfaction with the information format, so that responses need to be 


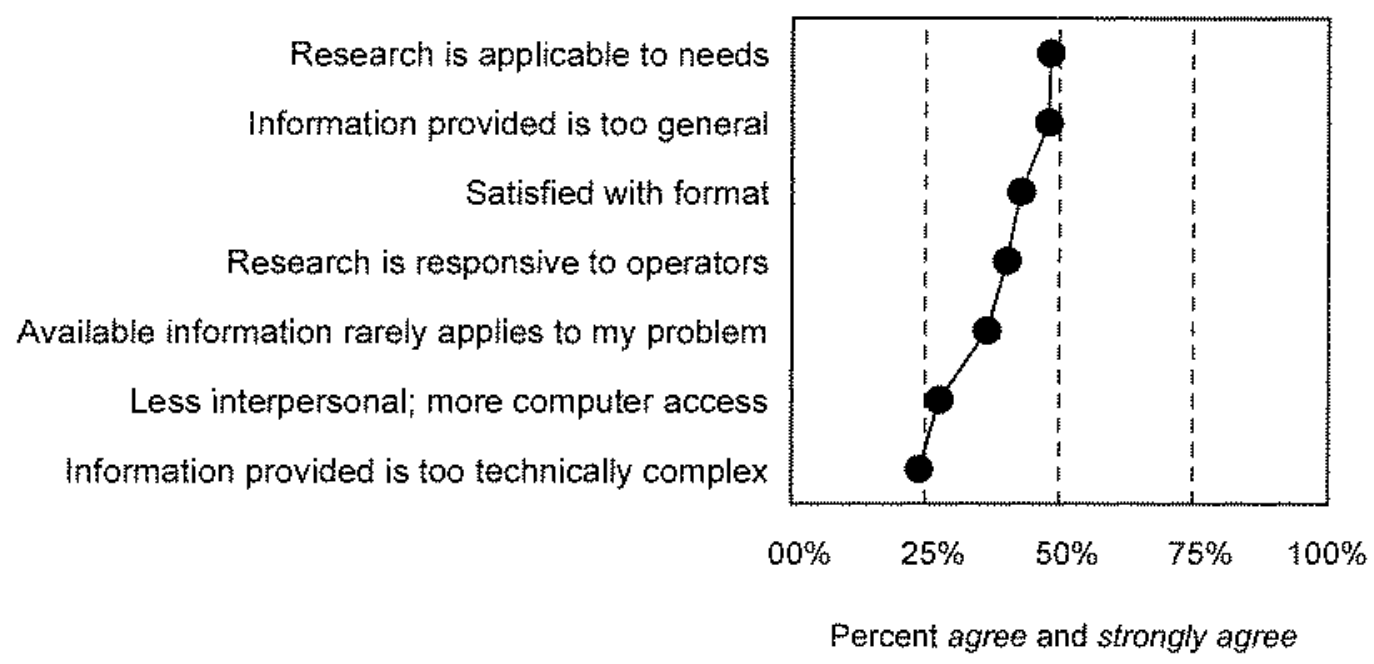

Figure 6.1. Quality of information format. Percent who circled agree or strongly agree on a four-point scale where $1=$ strongly disagree, 2 = disagree, $3=$ strongly agree, and $4=$ agree. $(\mathrm{N}=381)$

Source: Decision Research, Southern Interior Forest Extension Survey (1998).

interpreted in reverse (and, for these questions, a lower level of agreement signals a higher level of satisfaction). For example, a slight majority of respondents $(52.0 \%)$ either had no opinion or agreed that the general level of information provided by extension services is about right; this is shown in line two of the figure, where $48.0 \%$ of respondents agreed or strongly agreed with the statement that the information provided "is often too general to address site-specific circumstances." Only about one-third (36.5\%) of the participants agreed or strongly agreed that "available information rarely applies directly to my specific problem" (line 6) and less than one-quarter (23.9\%) of all participants agreed or strongly agreed that the information provided by extension services is "too technically complex to address site-specific circumstances."

A final question (line 7) regarding information format asked whether "in the future, most Partnership members will be satisfied if they receive less person-to-person contact with extension agents and more access to computer technologies." Just over one-quarter $(27.6 \%)$ of Partnership members agreed or strongly agreed with this statement, suggesting that - despite the many benefits of computer-based technologies - the desire for continued contact with individuals will remain high among Partnership members.

Figures 6.2 and 6.3 provide a breakdown of these results by group. As shown in Figure 6.2. there exist significant differences in the response patterns of provincial operations and policy employees, provincial researchers, and licensees. Provincial researchers 

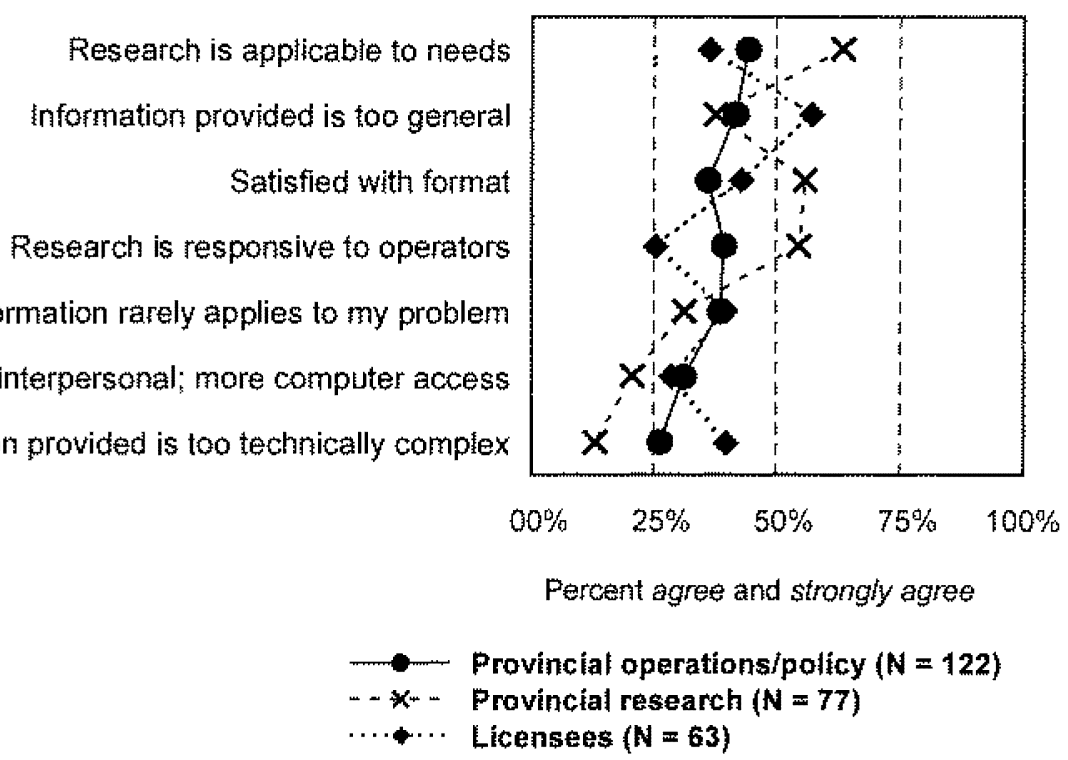

Figure 6.2. Quality of information format for three groups. Percent who circled agree or strongly agree on a four-point scale where $1=$ strongly disagree, $2=$ disagree, $3=$ strongly agree, and 4 = agree.

Source: Decision Research, Southern Interior Forest Extension Survey (1998).

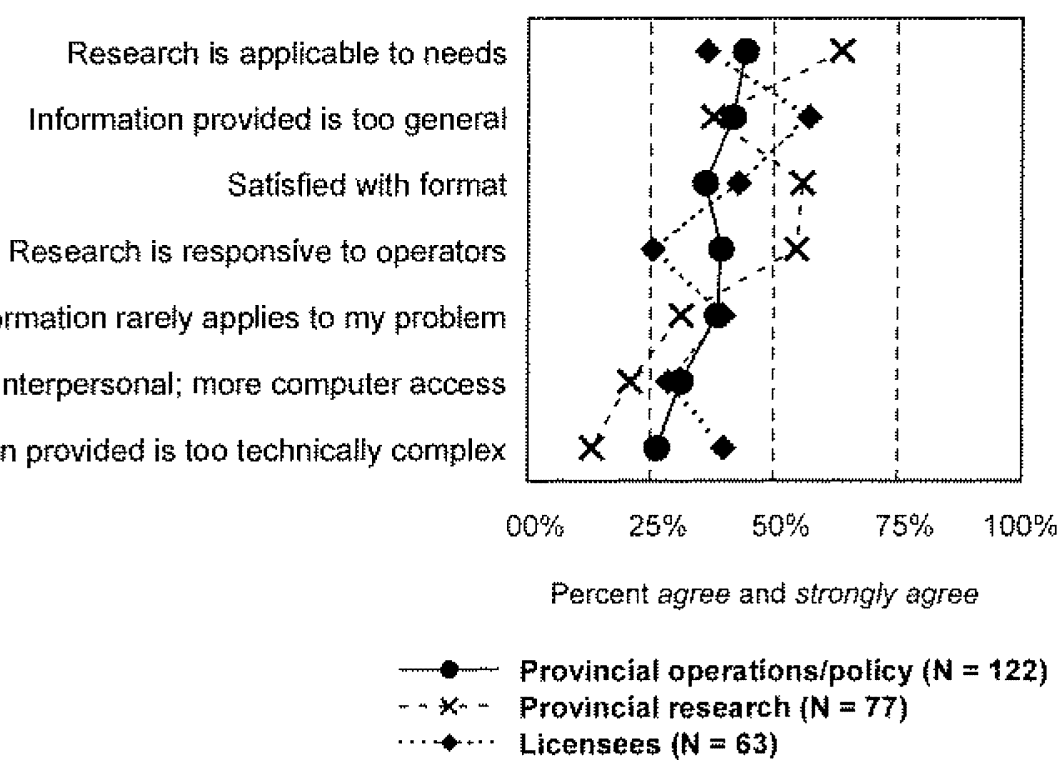

Figure 6.3. Quality of information format for three groups. Percent who cifcled agree or strongly agree on a four-point scale where $1=$ strongly disagree, $2=$ disagree, 3 = strongly agree, and $4=$ agree.

Source: Decision Research, Southern Interior Forest Extension Survey (1998), 
demonstrate the strongest support for the applicability of current research and its ability to address infornation needs. Provincial researchers also are more enthusiastic about the responsiveness of research to operators and the overall format of information.

Licensees are relatively more concerned with the technical complexity of information provided to them (line 8 ) and over one-half of all licensee respondents stated that the information provided to them is often too general to address their site-specific needs.

Figure 6.3 shows some similar variations in responses among private consultants, academic and federal researchers, and provincial operations/policy personnel. For example, a substantially higher percentagc of researchers $(65.4 \%$ vs less than $50 \%$ for operations/policy respondents and consultants) are confident that their work is applicable to the "information needs of the forest community" and that rescarch is rcsponsive to "the questions and issues important to operators directly responsible for land management" (line 4). As anticipated, researchers also are less concerned about problems with the technical complexity of information (line 7). Nearly two-thirds of private consultants are concerned that the information currently provided by extension services is too general, while only about one-third ( $35.4 \%$ ) of consultants feel that research is sufficicntly responsive to the needs of "operators directly responsible for land managemcnt." Provincial operations/policy respondents show the highest level of agreement with the statement that responding personnel are "very knowledgeable" and, surprisingly, the lowest level of agreement with the statement that information currently is provided "in a form that is clear and casy to follow."

\subsection{Trust in the Information Source}

The expressed level of trust in a source of information is significant, for many reasons. First, a higher level of trust means that information is more likely to be requested. Second, a higher level of trust means that information obtained from a source is more likely to be used. Third, trust in a specified source of information (e.g., an individual or a publication) typically carries over to other information provided by the same source, so that there are substantial indirect effects of addressing shortfalls in the perceived level of trust.

In this survey, participants were asked to state their level of trust in each of twenty-two selected potential sources of information about forest and range management topics. Responses were shown on the scale of "almost no trust," "a little trust," "a fair amount of trust," and "a lot of trust" as well as a fifth "don't know" option. The information sources were presented sequcntially and grouped by type, so that (for example) all sources of web pages or all sources of agency reports were answered in sequence. 
Overall results are shown in Figure 6.4 , with mean responses shown on the scale ranging from a low of 1 ("almost no trust") to a high of four ("a lot of trust"). The highest ranked sources of information are researchers already known to the respondent (mean $=3.68$ ), colleagues or co-workers (3.63), and professional journals (3.47). The lowest ranked sources of information are newspapers or topic-specific magazines (mean $=1.97$ ), the internet (2.38), and newsletters. Web pages also tended to rank quite low, with the exception of University web pages (mean $=3.14$ ). These results suggest the importance of previous and, when possible, personal contact with a source of information; for example, note the difference in rankings of "contractor already known to you" and "contractor previously unknown to you." They also suggest that significant problems remain in terms of increasing Partnership members' trust in the quality of most sources of electronic information. Overall, respondents hold a "fair amount of trust" in the majority of the sources noted in Figure 6.5 and, with the exception of the few items (noted above) that are ranked quite high or quite low, do not greatly distinguish among the level of trust held in most of the potential sources of information included in the survey.

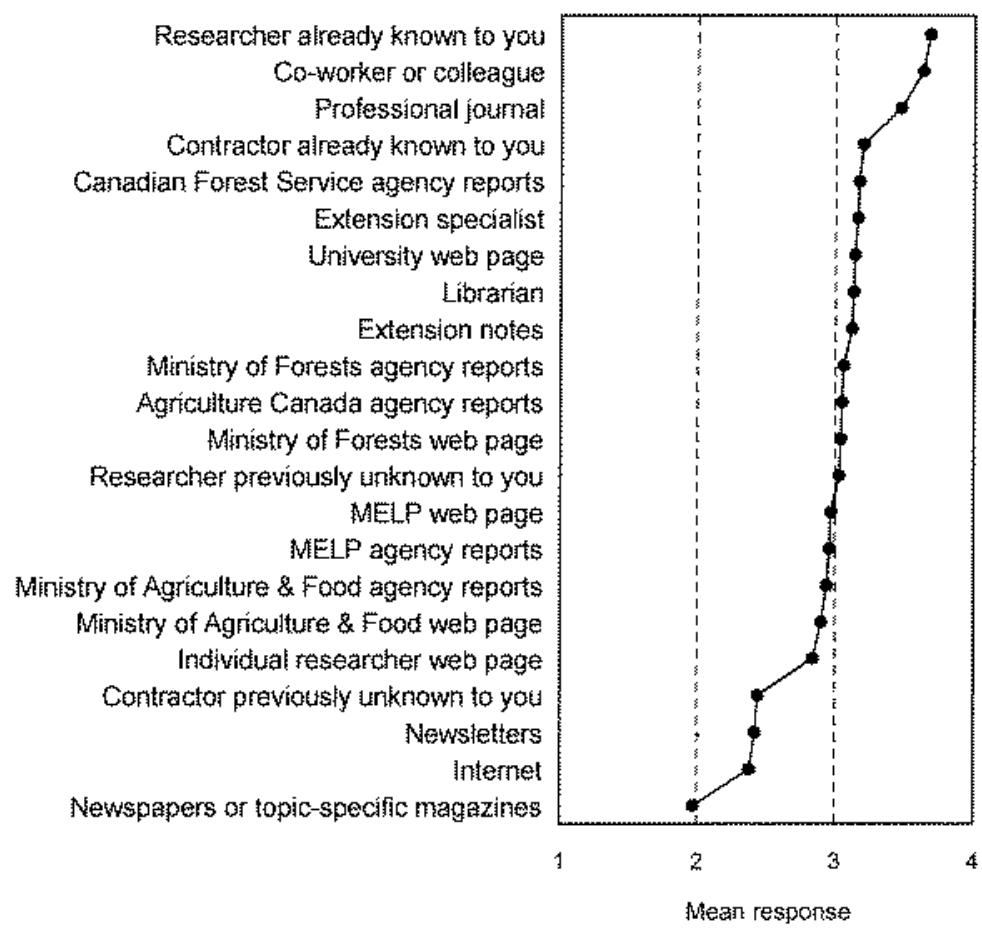

Figure 6.4. Trust of information format/source. Mean response on a four-point scale where $1=$ almost no trust, 2 = a fittle trust, $3=$ a fair amount of trust. and $4=$ a lot of trust. $(\mathrm{N}=381)$

Source: Decision Research, Southern tnterior Forest Extension Survey (1998). 
Figures 6.5 and 6.6 provide additional details on differences in trust of information sources among the five designated respondent groups. Provincial operations/policy employees hold the lowest trust in newspaper and magazine accounts and the greatest trust in known colleagues, co-workers, and professional journals. Not surprisingly, both academic/federal and provincial government researchers agreed with these rankings. Licensees and private consultants tend to hold a relatively lower level of trust in most of the sources of information, with the understandable exception of contractors already known to them.

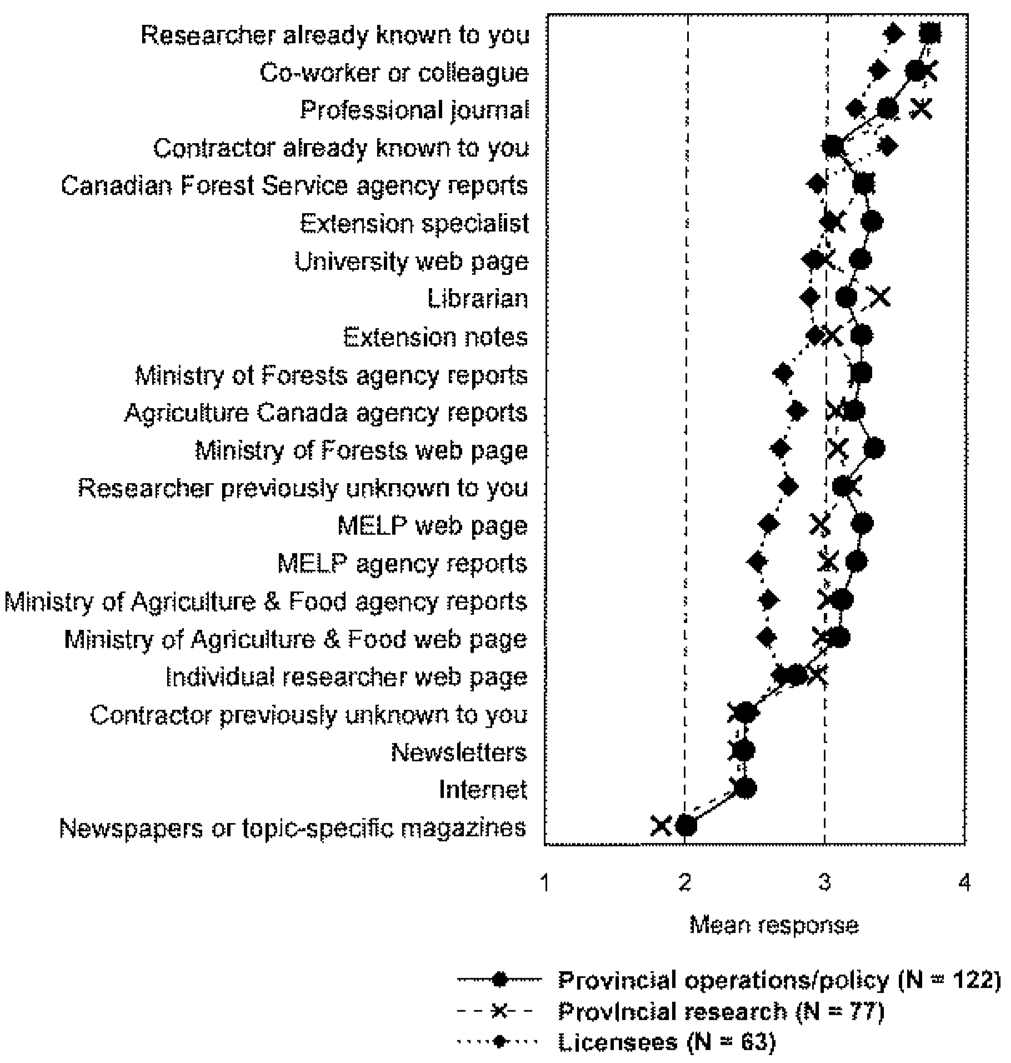

Figure 6.5. Trust of information formatisource for three groups, Mean response on a four of trust, and $4=$ a lot of trust.

Source: Decision Research. Southem Interior Forest Extension Survey (1998). 
Researcher alteady known to you

Coworker or colleague

Professional joumal

Contractor alteady known to you

Canadian Forest Service agency reports

Extension specialist

University web page

Librarian

Extension notes

Ministry of Forests agency reports

Agrictlure Canada agency reports

Ministry of Forests web page

Researcher previously unknown to you

MELP web page

MELP agency reports

Miristry of Agriculute \& Food agency reports

Ministry of Agriculture \& Food web page

Individual researcher web page

Contractor previously unknown to you

Newsletters

Internet

Newspapers or topic-specific magazines
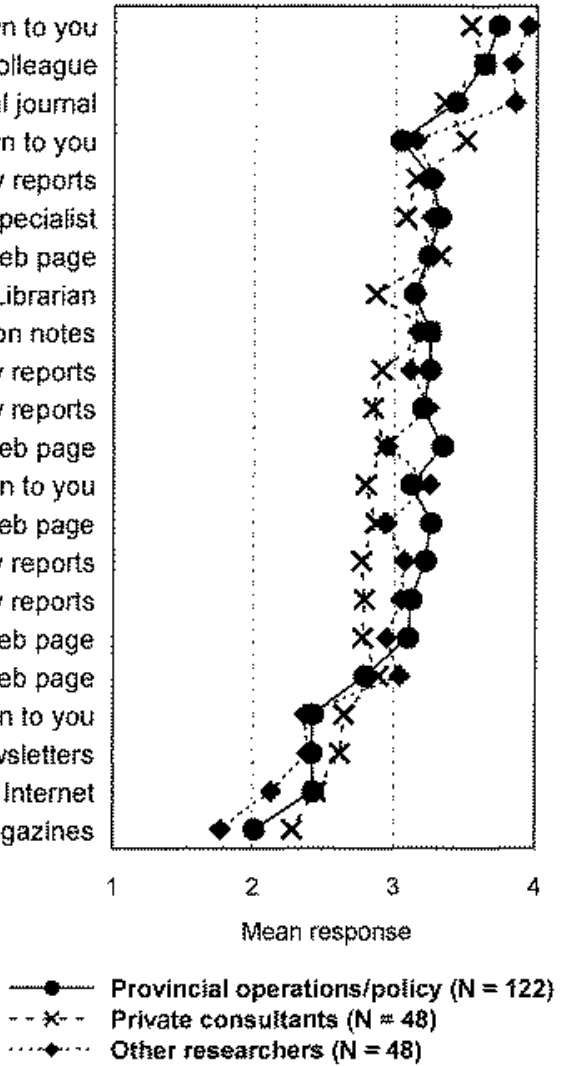

Figure 6.6. Trust of information format/source for three groups. Mean response on a four-point scale where $1=$ almost no trust, $2=$ a little trust $3=$ a fair amount of trust, and $4=0$ lot of trust.

Source: Decision Research, Southern interior Forest Extension Suvey (1998). 


\section{7}

\section{Technology Transfer}

The successful communication of extant and future forest science research results also depends on comprehensible and accessible vehicles for information transfer. User groups must be able to access eurrent information in a manner that is intellectually accessible and readily obtainable. Conversely, provider groups must be cognizant of the knowledge transfer requirements of user groups so as to permit efficient transmission of research findings. The following set of findings examines current avenues for technology transfer as stated by members of the Partnership. We then follow those findings with a set of questions that reveal preferred vehicles for technology transfer in light of the future development of the Southern Interior extension service.

The first set of questions asked the following of all respondents: In the past, when you have been faced with a guideline that needed interpreting or a land-management or jobrelated problem, where have you tumed? Respondents were asked to review a list [of information sources] and then eheck the three places where they most often found the needed information.

\subsection{Current Sources of information}

Figure 7.1 refleets a clear pattern of preference with regard to Partnership members' current and past sources of information, with two sources emerging as primary: a "com worker or colleague" (checked by $67.7 \%$ of the sample) and a "government researcher already known to you" (50.1\%). Web pages; known consultants, ageney reports and professional publications follow as the next most common sources of information, although these items were checked by only one-quarter of the sample. It is interesting to note that personal contact or seeking out a "known" colleague appears important to many Partnership members and that scholarly articles are consulted with some regularity, despite the fact that many participants in the pre-survey focus groups regarded professional publications as too technical or arcane to be useful. $\mathrm{lt}$ is also interesting to note that web pages are emerging as popular sources of information despite their newness 
relative to the other information sources (and problems of information quality as noted in Chapter 6). Finally, these findings refleet the degree to which Partnership members rely not on academic researchers but on the government's research community ("known government researcher") to provide necessary information.

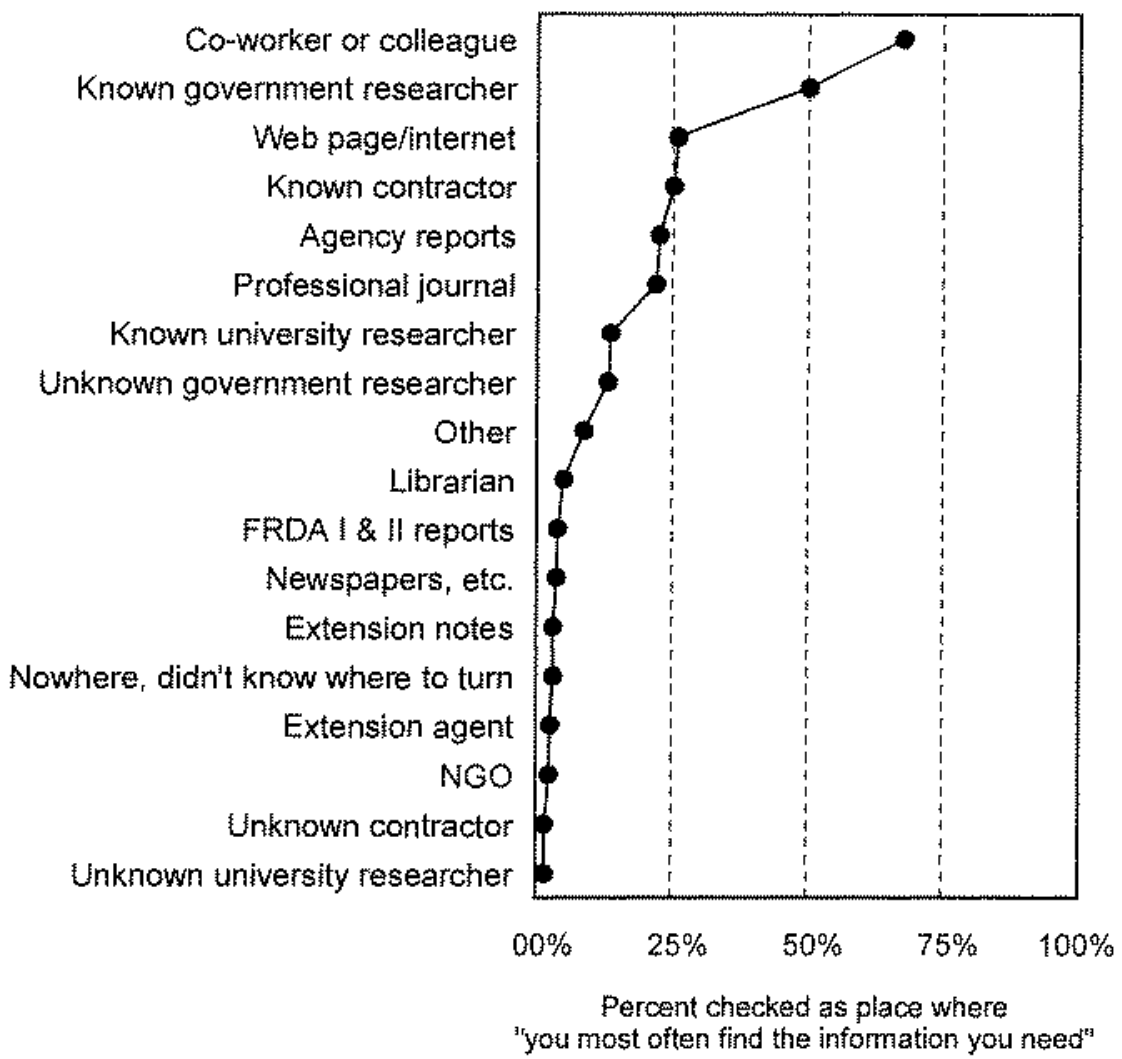

Figure 7.1. Current sources of information. $(N=381)$

Source: Decision Research, Southern interior Forest Extension Survey (1998).

Figure 7.2 considers the differences across three respondent groups (provincial government researchers, provincial government policy and operations personnel, and private sector licensees) with regard to preferred sources of information. In this figure, co-workers and known government researchers retain their status as the primary sources of information but important differences of opinion about information sources energe. First, both members of the operations and policy branch and private contractors or licensees demonstrate a marked tendency to seek advice from their own, immediate colleagues. As shown in Figure 7.2, over $50 \%$ of contractors seek advice from other contractors (compared to the less than $20 \%$ of provincial government respondents that 
turn to contractors for advice); similarly, operations and policy personnel prefer the advice of their own colleagues to a greater degree (by about 20 percentage points) than do provincial researchers or licensees. These between-group differences also contradict the evidence reported above (Figure 7.1) regarding support for joumal articles and professional publications. Some part of this support is driven solely by the research community as this group (provincial government researchers) appears more likely (by at least 20 percentage points) to seek out publications than do representatives from the other two samples (operations/policy and licensees). Finally, though support for web pages may be growing, Figure 7.2 demonstrates that representatives from the operations and policy branches are more likely to pursue information from agency reports and web pages than either their research or licensees colleagues.

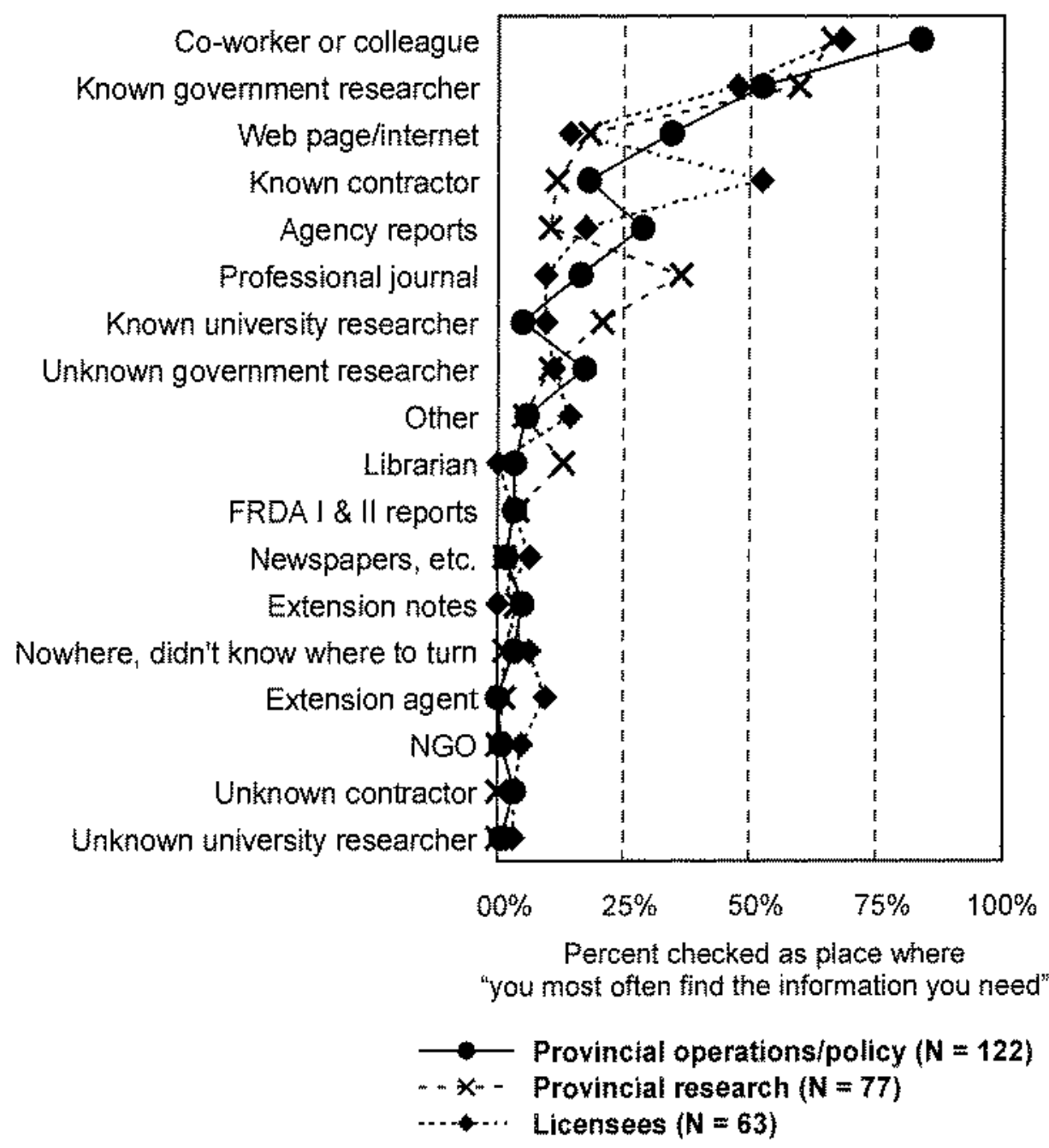

Figure 7.2. Current sources of information for three groups.

Source: Decision Research, Southern Interior Forest Extension Survey (1998). 
Figure 7.3 indicates that operations and policy personnel, private consultants, and federal and academic researchers generally tend to work within the confines of their immediate colleagues when seeking information. This evidence suggests that Partnership members may be resistant to the exchange and integration of information across groups. Federal government and academic researchers, for example, are much more likely to seek advice from other "known university reseatchers" whereas their operations personnel and consultants generally reject the academic and federal agencies as primary sources of information. Consultants tend to turn primarily to "known contractors" for information, yet that same source of infornation (contractors) is sought out by very few federal and academic researchers and fewer than $20 \%$ of personnel from operations and policy. Finally, while all three groups turn most often [or second most often] to co-workers for advice, provincial employees fron operations and policy demonstrate something akin to a communicative tunnel-vision in that more than $80 \%$ of this subgroup stays within their operations/co-worker network when seeking information.

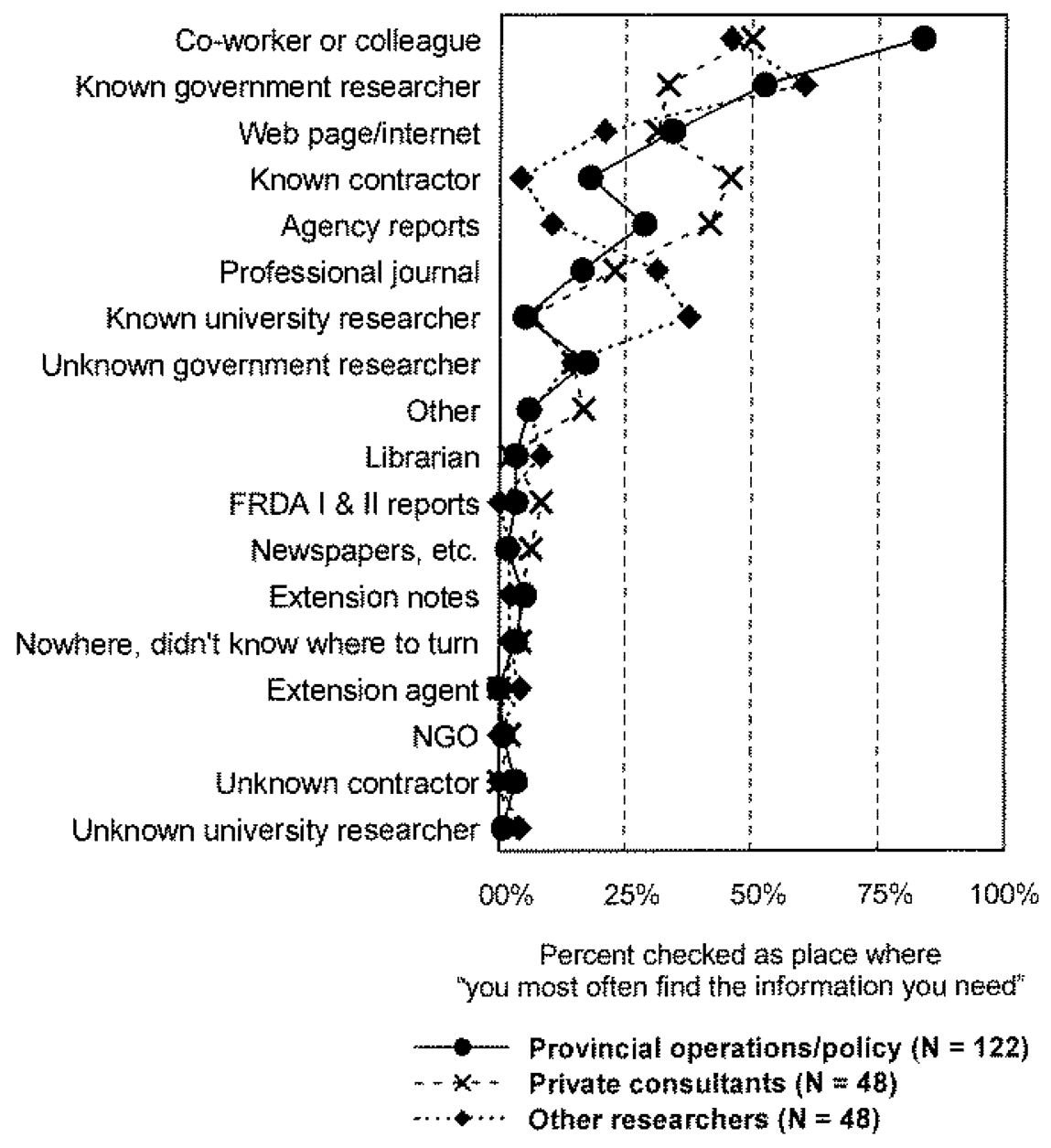

Figure 7.3. Current sources of information for three groups.

Source: Decision Research, Southern Interior Forest Extension Survey (1998). 
As extension services develop it will become necessary to focus resources on those methods of technology transfer that best serve Partnership constituents. Difficult choices will have to be made between the appropriateness of professional conferences or instructional videos when compared to the desirability of field guides or field days at demonstration forests. To inform these choiccs, respondents were presented with a list of 16 different methods for the transfer of information. They were then asked to rate each vehicle on several dimensions using a five point scale with opposing cndpoints. Two of the scales had the following endpoints:

\footnotetext{
- "Will not reach key personnel" versus "Will reach key personnel"

- Not likely to be used" versus "Likely to be used"
}

In Figure 7.4 on the next page, these dimensions are plotted together on an $x-y$ axis; the $x$ axis reflects ability for method of transfer to reach key personnel, while the $y$ axis considers likelihood of use. The figure is divided into four quadrants. The upper right quadrant represcnts the items for which a majority of respondents ${ }^{\prime}$ both agrecd that the method would be used and agreed that the method would reach key personnel. Conversely, the lower left quadrant represents those items that were rated as not likely to be used and not likely to reach key personnel.

Five methods of information or technology transfer are judged as likely to be used and should be likely to reach key personncl relative to all othcr transfer methods. In descending order of preference, these are: interpretive guides and field guides, web sites, extension notes, workshops with field components, and on-site visits by extension personnel. Interpretive and ficld guides are particularly popular, in that a substantial majority of all respondents regard this vehicle as likely to be used and accessible to key personnel.

${ }^{1}$ Here, a majority represents all those who circled 4 and 5 on a five-point scale; those who circled a 3 (neutral), 2 , or 1 were regarded as not fully supportive of the method on that dimension (e.g. likelihood of use). 


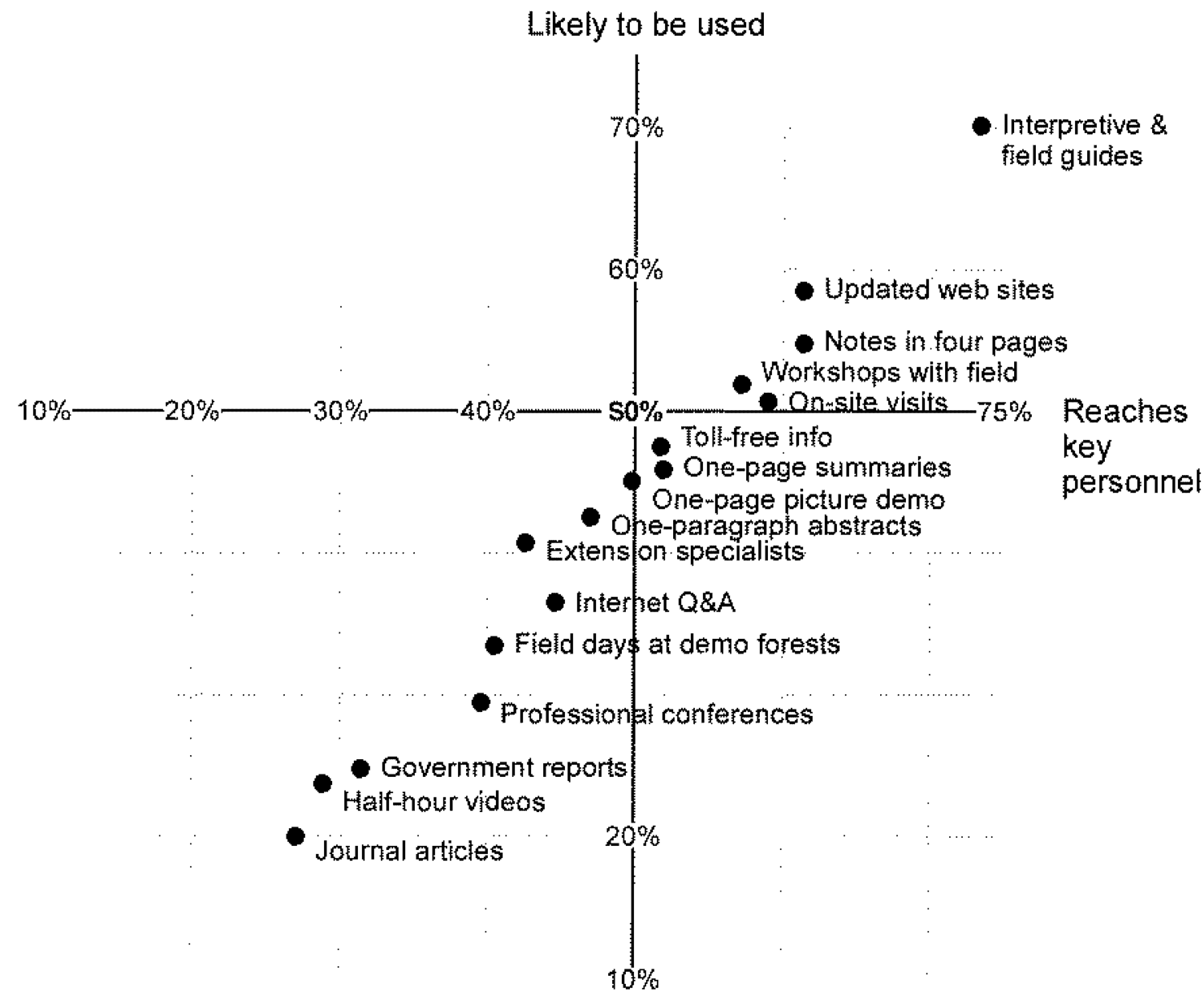

Figure 7.4. Preferred method of transfer based on audience reach ("reaches key personnel") and likelihood of use. Percent who circled 4 or 5 on a 5-point scale where, for the $X$ axis, $1=$ will not reach key personnel and $5=$ will reach key personnel and, for the $\mathrm{Y}$ axis, $1=$ not likely to be used and $5=$ likely to be used.

Source: Decision Research, Southern Interior Forest Extension Survey (1998).

cynterremof graphics 174. cdr, 9-25-98 


\subsection{Preferred methods of information transfer}

Because the decision about where exactly to invest extension resources must also consider cost, a third seale was used with the above 16 items to examine preferences for these methods given "limited funds." Again, using a five-point scale, respondents were asked to rate each item where 1 -" "low priority given limited funding" and $5=$ a "high priority given limited funding.:"

Figure 7.5 distinguishes clearly between methods of information transfer that are broadly preferred given limited funding versus those which are preferred by a small percentage of respondents. Regularly updated computer web sites stand out as supported by $55 \%$ of all respondents (given limited funding); cxtension notes not exceeding four pages in length and interpretive guides are supported by approximately $46 \%$ of respondents. Conversely, the production of half-hour instructional videos, journal articles and the staging of professional conferences are regarded as a priority by only $18 \%$ or fewer respondents. Workshops remain in the top five preferred sourees of information, but on-site visits lose some of their popularity when framed here as a cost-derived preference.

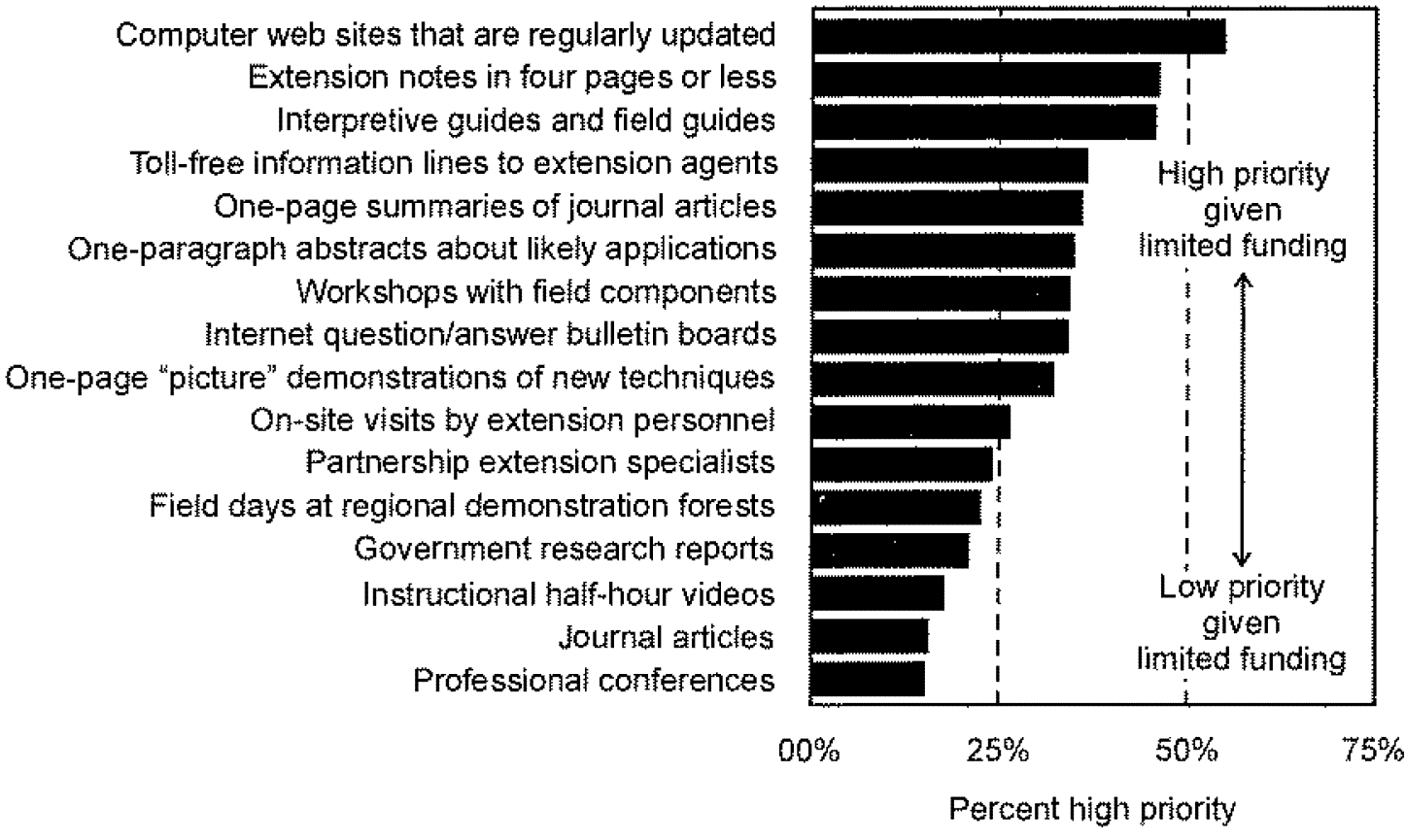

Figure 7.5. Preferred methods for information transfer. Percent who circled 4 or 5 on a 5 point scale from 1 (low priority given limited funding) to 5 (high priority given limited funding $).(\mathrm{N}=381)$

Source: Decision Research, Southern Interior Forest Extension Survey (1998).

cynterehmof graphicsi7-5.cot 9-28-98 
Overall, respondents tend to favor those items that offer short, concise modes of delivery (brief extension notes, one-page summaries of findings, etc.) when rating preferences on the basis of cost. Eventually, conflicts between preferences based on cost versus those based on likelihood of use or sufficiency at reaching key personnel, will have to be resolved in the design and implementation of the Southern Interior extension program. ${ }^{2}$

Figure 7.6 (see next page): Once again, several between-group differences emerge when comparing the responses of provincial government researchers, operations and policy personnel, and licensees. The largest between-group differences are those that separate the licensees from members of the provincial government"s research and policy operations branches. In particular, licensees are less supportive of computer support in the form of web sites and internet bulletin boards than are provincial operations/policy or research personnel. Conversely when faced with a limited budget, licensees are much more likely than members of the other two respondent groups to prefer one-page "picture" demonstrations of new techniques and to favor on-site visits by extension personnel. Finally, members of the provincial research community differ from both operations/ policy personnel and from licensees in that they are much less likely to support the introduction of toll-free information lines that would access extension agents.

${ }^{2}$ Only a minority of respondents in all groups agree that "extension services should operate on a cost-recovery basis" or a "fee for service basis." These results are contained in Appendix B-Cost Considerations. 


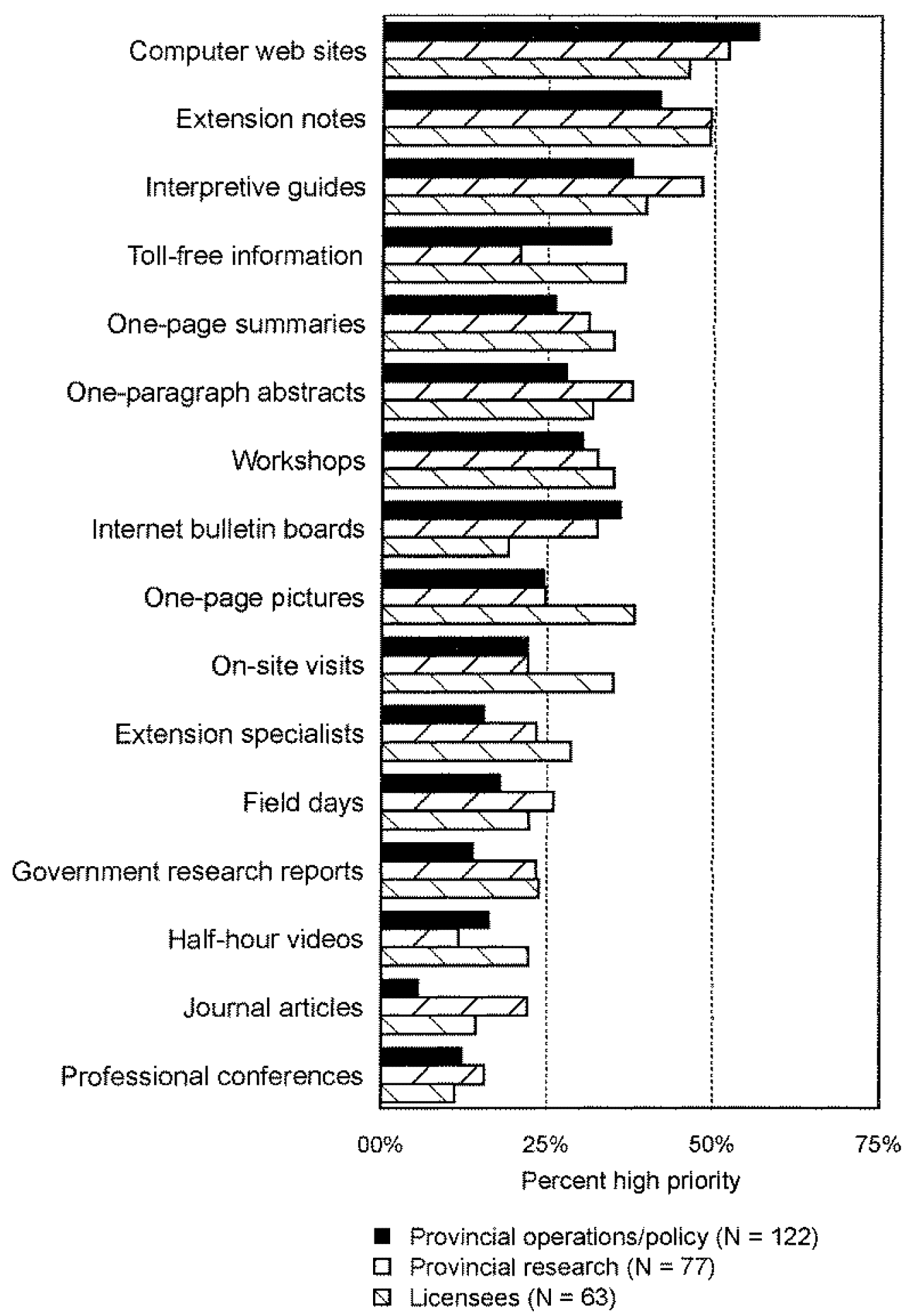

Figure 7.6. Preferred methods for information transfer for three groups. Percent who circled 4 or 5 on a 5-point scale from 1 (low prionity given limited funding) to 5 (high priority given limited funding).

Source: Decision Research, Southern Interior Forest Extension Survey (1998). 
Figure 7.7 demonstrates that private consultants and federal and academic researchers also differ from operations/policy personnel regarding the utility of different technology transfer methods given limited funding. When compared to constltants and researchers,

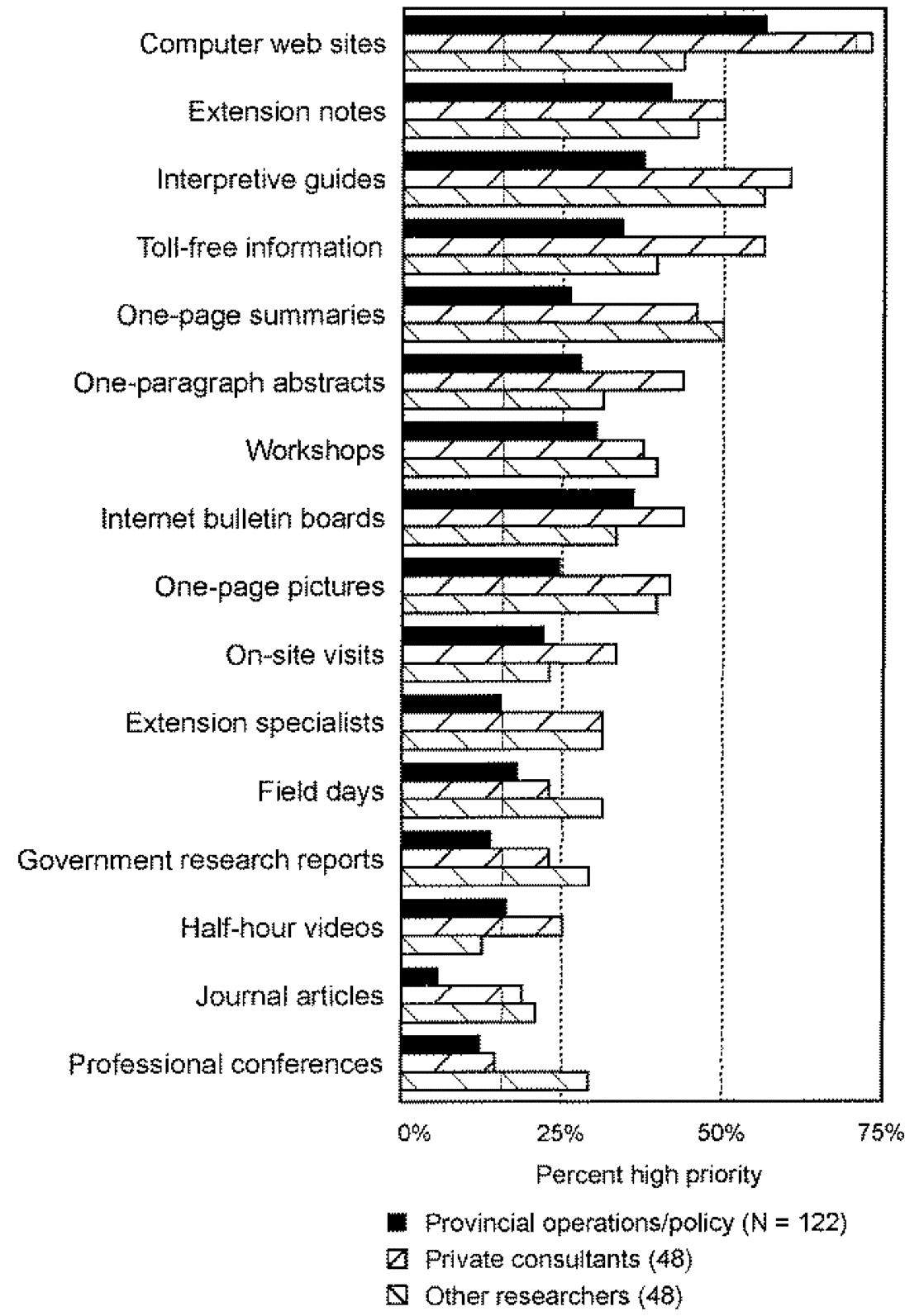
operations/policy personnel are less likely to support interpretive guides and field guides, one-page summaries of journal articles, and one-page picture demonstrations of new techniques.

Also, when considering cost or "limited funding," private consultants are more likely than either operations personnel or researchers to support web pages (though operations support for web pages is still high), toll-free information lines, and a directory of Partnership research projects containing one-page abstracts.

Figure 7.7. Preferred methods for information transfer for three groups. Percent who circled 4 or 5 on a 5-point scale from 1 (low priority given imited funding) to 5 (high prionity given imited funding).

Source: Decision Research, Southern Interior Forest Extension Survey (1998). 


\subsection{Tradeoffs across Technology Transfer Options}

It is often easier for individuals to consider choices about preferred technology transfer options, by comparing one choice to another. Indeed, paired choice comparisons ean purge a decision of some of its abstract qualities, thereby helping respondents to clarify their own thinking. For this reason, we chose fourteen of the technology transfer options and broke them into pairs. Respondents were asked to consider both items and to select the one item in each pair that they considered most important.

Table 7.1 presents responses for the entire sample as well as those for each individual sub-sample. Respondents across all sample groups (column 1) are much more likely to prefer interpretive guides to computer models (by a margin of about $5: 1$ ), and prefer "a directory of recent case studies accompanied by short statements about their application" to "reprints of journal articles on topics of interest" (by a margin of nearly $4: 1$ ). Workshops at rcgional demonstration forests are preferred over instructional half-hour videos (by more than a 2:1 margin), while newsletters summarizing journal articles and conferences are preferred over attendance at professional conferences (by about 2:1). Only two pairs of items are elose: on-site visits as comparcd to toll-free extension services, and Internet bulletin boards comparcd to one-page picture demonstrations.

The ovcrall pattern of preferences across technology transfer options remains more or less stable when considering the choices selected by respondents from the five sub-sample groups. Though some variation occurs, between-group differences tend not to exceed $10 \%$ or $15 \%$. There are three exceptions to this pattern: provincial operations/policy personnel are more apt to prefer web pages over extension notes than are licensees; provincial researchers prefer on-site visits by extension agents to toll-free information lines, whereas private consultants prefer the toll-free lines; and federal and university researchers are more supportive of article reprints, and less supportive of instructional videos, than are members of other groups.

In general, web sites fare better than extension notes when a comparison between the two is posed. This support, however, is heavily driven by the strong endorsement of web sites offered by provincial research staff and by operations/policy personnel. Case studies with short statements about their application appear more useful to all Partnership members, and field guides retain their popularity as important sources of information across all groups even when compared to sophisticated (and often expensive) computer modeling technologies. 
Table 7.1. Tradeoffs: percent choosing each item as most important when paired with another item from this list.

\begin{tabular}{|c|c|c|c|c|c|c|c|}
\hline & Question Pairs & jotat & $\begin{array}{c}\text { Lieen- } \\
\text { sees }\end{array}$ & $\begin{array}{l}\text { Private } \\
\text { consul- } \\
\text { tandis }\end{array}$ & $\begin{array}{l}\text { Plovincial } \\
\text { opcrations } \\
\text { policy }\end{array}$ & $\begin{array}{l}\text { Provincial } \\
\text { research }\end{array}$ & $\begin{array}{c}\text { Other } \\
\text { researchers }\end{array}$ \\
\hline \multirow[t]{2}{*}{129} & Updated agency intemet web pages & $58.3 \%$ & $44.4 \%$ & $54.2 \%$ & $68.9 \%$ & $63.6 \%$ & $47.9 \%$ \\
\hline & Extension notes (4 pages or less) & $39.4 \%$ & $50.8 \%$ & $45.8 \%$ & $29.5 \%$ & $35.1 \%$ & $47.9 \%$ \\
\hline \multirow[t]{2}{*}{130} & On-site visits by extension agents & $45.4 \%$ & $52.4 \%$ & $31.3 \%$ & $39.3 \%$ & $59.7 \%$ & $47.9 \%$ \\
\hline & $\begin{array}{l}\text { Toll-free information lines to } \\
\text { extension agents }\end{array}$ & $5+.4 \%$ & $42.9 \%$ & $68.8 \%$ & $58.2 \%$ & $37.7 \%$ & $45.8 \%$ \\
\hline \multirow[t]{2}{*}{131} & Reprints of joumal articles on topies & $707^{6} b$ & $13^{0}$ & 5460 & 1560 & $260^{0}$ & $A: 70 /$ \\
\hline & Difectory of recent case studies & $76.6 \%$ & $81.0 \%$ & $85.4 \%$ & $82.0 \%$ & $71.4 \%$ & $54.2 \%$ \\
\hline \multirow[t]{2}{*}{132} & Instructional hatf-hour videos & $30.2 \%$ & $38.1 \%$ & $39.6 \%$ & $31.2 \%$ & $22.1 \%$ & $16.7 \%$ \\
\hline & $\begin{array}{l}\text { Workshops at regional demon- } \\
\text { stration forests }\end{array}$ & $67.7 \%$ & $55.6 \%$ & $60.4 \%$ & $68.0 \%$ & $76.6 \%$ & $79.2 \%$ \\
\hline \multirow[t]{2}{*}{133} & Professionat conferences & $33.1 \%$ & $31.8 \%$ & $18.8 \%$ & $28.7 \%$ & $46.8 \%$ & $35.4 \%$ \\
\hline & $\begin{array}{l}\text { Newsletter summatizing recent } \\
\text { conferences \& publications }\end{array}$ & $63.8 \%$ & $61.9 \%$ & $79.2 \%$ & $70.5 \%$ & $50.7 \%$ & $58.3 \%$ \\
\hline \multirow[t]{2}{*}{134} & One-page picure demonstrations & $49.6 \%$ & $55.6 \%$ & $56.3 \%$ & $45.9 \%$ & $45.5 \%$ & $47.9 \%$ \\
\hline & Internet Q\&A bulletin boards & $45.7 \%$ & $36.5 \%$ & $41.7 \%$ & $51.6 \%$ & $46.8 \%$ & $45.8 \%$ \\
\hline \multirow[t]{3}{*}{135} & Computer models & $13.6 \%$ & $15.9 \%$ & $16.7 \%$ & $16.4 \%$ & $9.1 \%$ & $8.3 \%$ \\
\hline & $\begin{array}{l}\text { Interpretive guides, ficld guides, or } \\
\text { govemment repors }\end{array}$ & $82.9 \%$ & $77.8 \%$ & $83.3 \%$ & $82.0 \%$ & $87.0 \%$ & $87.5 \%$ \\
\hline & $N=$ & 381 & 63 & 48 & 122 & 77 & 48 \\
\hline
\end{tabular}

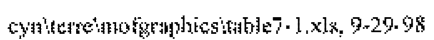




\subsection{Location of Extension Staff}

A final few somewhat exploratory questions asked all respondents to consider what kind of extension staff was preferred and where in the province that staff should be located. Questions posed to respondents are shown helow, with distribution scores reported at the end of each choice.

\section{Choose One of Two:}

A skilled librarian capable of responding to requests for materials on land- and resource-management. He or she would potentially reside in the Southern Interior, and be available through a toll-free line, fax or E-mail (21\%).

OR

A skilled networker capable of linking a person with a research or operations question to the individual within the Partnership best able to answer questions. He or she would reside in the Southern Interior, but be available through a toll-free line, fax, or E-mail $(76 \%)$.

The preferred choice across the two options in this question set is clear: An overwhelming percentage of Partnership members prefer networking services to library services. This choice is consistent with earlier findings in that responses across several of the communication questions in chapter 5 indicated difficulty in locating the person with expertise that best suited a problem or question. This suggests that Partnership members are not currently stymied by a lack of information per se, but rather run into frequent difficulty finding a human source of that information with whom they can discuss site- or topic-specific management problems. Each of the five individual Partnership groups supported the choice of a Southern Interior based networker at a level that was similar to that of the entire sample. 
The second item in this question set compared skill level and location of extension staff. The questions and response distributions are shown below.

\section{Choose One of Three:}

A small number of highly skilled extension agents, working in the vicinity of Nelson, Kamloops, or Williams Lake, capable of answering very specific questions about the management of resources $(72.6 \%)$.

OR

A larger number of moderately skilled extension agents capable of answering basic questions about the management of resources. These individuals would work in the vicinity of Nelson, Kamloops, and/or Williams Lake $(19.3 \%)$.

\section{OR}

A small number of highly skilled extension agents working out of Victoria capable of answering very specific questions about the management of resources $(4.5 \%)$.

Results show a strong preference for a skilled extension agent located in the Southern Interior. Respondents expect the agent to be competent to the degree that specific concerns can be addressed, and they endorse a smaller number of skilled personnel at the expense of a possibly larger (though less skilled) extension staff. This result reemphasizes the need of Partnership members to address specific, detailed problems and their support for locally-available and responsive agents sited in Interior communities such as Nelson, Kamloops, and Williams Lake. 


\section{8}

\section{Conclusion}

This study reports the results of a survey conducted for the British Columbia Ministry of Forests, Forest Renewal B.C., and the B.C. Science Council during the summer of 1998 on behalf of the Southern Interior Forest Extension and Research Partnership. The survey was designed to help the Southern Interior extension service identify and prioritize the primary information necds of Partnership members, evaluate alternative methods for information transfer, elicit key concerns regarding the quality of information, and identify areas of agreement or disagreement with respect to these issues among different client groups within the Partnership. Responses were obtained from a broadly representative sample of Partnership clients, including separate responses from five groups: provincial opcrations and policy personnel, provincial researchers, licensecs, private consultants, and other (academic and federal government) researchers. In addition, smaller samples were obtained from selected First Nation (Shuswap Nation Tribal Council and the Okanagan Nation Alliance) and nongovernmental (NGO) participants.

The study results demonstrate broad agrecment on several key goals and objectives of an extension service for the Southern Interior, with emphasis placed on getting information effcctively from experts to potential users and on the continued development of a responsive knowledge base. Respondents look to the extension service for assistance on a variety of topics relating to forest management and harvest, including questions on the best practices to use for riparian management and biodiversity, on their legal responsibilities under the Forest Practices Code, and on the economic costs and benefits of a varicty of both timber and non-timber (c.g., recreation) based activities. However, the study also found substantial disagreements among clicnt groups regarding the prioritics that should be assigned to certain extension services. In particular, a fundamental tension exists across groups regarding support for an expert-driven versus user/operator-driven research agenda. The Partnership must address this tension in order to build a successful, mutually respected service. In addition, the survey results show striking differences in the perceptions of key groups regarding the success of current extension services in mecting the concerns of most importance to Partnership clicnts. 
Recent changes in forestry praetices in the Province have led to a clear need for additional information relating to the application of sustainable forest practices, the incorporation of First Nations in forest-management decisions, and the need to achievc on-the-ground practices that are both scientifically defensible and acceptable on the basis of emerging social, legal, and ecological eriteria. Licensees, consultants, and provincial operations personnel report this most strongly, and the survey results demonstrate both their frustration and the pereeived need for a more timely and topic-specific extension scrvice. For example, these three user groups place a high priority on interpreting guidelines set out in the Forest Practices Codc and they are dissatisfied with the length of time required to move idcas from the realm of research to on-the-ground applications. These same groups also seek information that is more specific with respcct to content and expressed in language that is less technically demanding.

Survey participants from the provincial and federal/academic rescarch groups, in contrast, are less concerned about information being too gencral or overly complex and place a lower priority on the rapid dissemination of research results. In addition, researchers are far less likely than other groups to want to "base research goals on Partnership member needs." This in part explains the dramatic difference in clients" opinions as to whether the needs and ideas of information users are sufficiently integrated into the current research agcnda: research groups are morc comfortable with the status quo, whereas licensees and consultants arc nearly unanimous in their belief that the current integration of their idcas is insufficient.

Large differences of opinion also show up betwecn the research community and other client groups in the context of information needs concerning social, economic, and cultural issues. For example, provincial operations/policy, consultants, and licensee groups all place a high priority on the provision of improved information about recreational values, stakeholder consultations, and First Nation uses of particular sites. Improved information on the economic costs and benefits of actions also is scen as important by these groups. Both research communities place a significantly lower emphasis on these types of issues, which makes sense in light of a natural disciplinary distinction: most scientists involved in our research sample have backgrounds in the physical sciences, whereas these issues typically are the concern of social scientists. This samc split shows up in other contexts, such as the high priority given by licensees, consultants, and provincial opcrations/policy respondents to the development of improved decision tools and the low priority assigned to this task by research personnel. Although it is unrealistic to expect physical scicntists to respond fully to this need for improved social-science information and techniques, it is equally unlikely that opcrations personnel will be able to mect emerging social, ceonomic, and cultural criteria without the provision of additional guidance and tools through a revised extension service. 
Another area of rapid change facing Partnership extension services is the incoporation of new clients and new perspectives from First Nations and from a variety of NGOs. Although the process followed in this survey was not aimed at responding to the needs of these stakeholder groups, we believe that it is essential for their requirements, insights, and perspectives to be integrated more fully with those of conventional users of extension services in the Southern Interior.

These inter-group differences explain, at least in part, results obtained to questions concerning the level of trust placed in various sources of information. Partnership clients demonstrate a high degree of insularity with respect to who they trust; licensecs typically seek information from other liccnsees, MOF staff ty pically seek information from other MOF staff or the MOF web page, and so forth. These patterns of own-group reliance should be watched closely because they can limit the diversity, relevance, and scope of information that is brought to bear on a problem.

Two final points are relevant to the development of a state-of-thc-art cxtension service. Relative to all other modes of information delivery, five modes emcrge as "likely to be used" and likely to "reach key personnel." They are: interpretive guides and field guides, updated web sites, extension notes in four pages or less, workshops with field components, and on-site visits by extension personnel. Secondly, when asked to trade some priorities over and above others, the vast majority of clicnts prefer a service that is located (geographically) in the Southern Interior of B.C. and that prioritizes networking (linking operators and researchers) skills over archival ("library") services per se.

The overall picture that is presented by these results is one of an extension service in flux. There are many areas where clients clearly feel that additional information needs to be provided to help them meet the demands of changing times. Significantly, these demands embrace not just traditional sources of forest research and operations but also new topic areas relating to changing management practices and dramatic alterations in the social, economic, and legal landscape within which Partnership members function on a daily basis. There are also substantial differences in the types of activities and efforts that respondents believc should provide the focus for a renewed and improved extension service. The results of this survey are intended to add to the current understanding of Partnership client needs and to assist with the redesign of extension services so that existing information and tools can be used more fully at the same timc that attention is given to the provision of new information and tools, responsive to the emerging needs and perceptions of Partnership clients. 
Appendix A: Client Needs Survey 


\section{Southern Interior Forest Extension Survey}

Greetings. The enclosed survey is part of a collective effort to develop a more effective extension service for the Southem Interior of the province. The goal of the extension service is to promote information exchange, problem solving, research development and localized learning about resource management.

The questions were developed on the basis of meetings with government resource professionals, licencees, consultants, First Nations, researchers, and other members of the Southem Interior Forest Extension and Research Partnership (hereafter referred to as "the Partnership"). The Partnership is a consortium of organizations working to link all parties with a strong interest in developing, exchanging, and using knowledge about sustainable land management in decisions about British Columbia's forests.

You've been selected from the larger Partnership to participate in this survey. Your responses will help shape a new extension program to be offered in the Southern Interior of B.C. We hope that you will consider each question carefully and that you will not hesitate to offer any additional comments or creative thinking that might be useful. All responses are anonymous and the results will be available in report form by the fall of 1998 .

Robin Gregory and Theresa Satterfield DECISION RESEARCH, Vancouver, B.C.

Decision Research

2206 East Mall $-4^{\text {*ै }}$ Floor

Centre for Human Settlement

University of British Columbia

Vancouver, $\mathrm{BC}$ V6T 123
Chris Hollstedt, Managing Director

Southern Interior Forest Extension \& Research Partnership c/o Kamloops Forest Region

515 Columbia Street

Kamloops, BC V2C 2T7 
1. The following is a list of different categories of persons or employees who are members of the Partnership. Please check the one category that primarily applies to you.

Licensees:

$$
\begin{aligned}
& \text { Q1. Major Forest Licensees } \\
& \square{ }_{3} \text { Minor Forest Licensees } \\
& \square{ }_{4} \text { Grazing Licensees }
\end{aligned}
$$

- Private Consultant: $\square 5$ Operations-Planning

$$
\square_{6} \text { Operations-Research }
$$

- Provincial Government-

Victoria-based:

$$
\begin{aligned}
& \square_{7} \text { Operations } \\
& \square_{8} \text { Policy } \\
& 9 \text { Research }
\end{aligned}
$$

- Provincial Government-

Southern Interior:

$$
\begin{aligned}
& \square_{10} \text { Operations } \\
& \square_{11} \text { Policy } \\
& \square_{12} \text { Research }
\end{aligned}
$$

- Other Researchers:

$$
\begin{aligned}
& \square_{13} \text { Federal Government Researchers } \\
& \square_{14} \text { Industry Research Personnel } \\
& \square_{15} \text { College and University Research Personnel }
\end{aligned}
$$

- First Nations:

$$
\begin{aligned}
& \square_{16} \text { Learning Institutions (e.g., En'owkin Leaming Center) } \\
& \square_{17} \text { Natural Resource Specialist } \\
& \square_{18} \text { Individual from Tribal Council } \\
& \square_{19} \text { FRBC First Nation Coordinators }
\end{aligned}
$$

- Field Contractors:

$\square_{20}$ Small Contractors

- Other:

$\square_{22}$ Member of Conservation or Environmental Group
$\square_{23}$
(other)

2. On average, what proportion of your work time is devoted to actively providing information to users?

$$
\begin{array}{ccccccccccc}
0 \% & 10 \% & 20 \% & 30 \% & 40 \% & 50 \% & 60 \% & 70 \% & 80 \% & 90 \% & 100 \% \\
\square_{1} & \square_{2} & \square_{3} & \square_{4} & \square_{5} & \square_{6} & \square_{7} & \square_{8} & \square & \square_{10} & \square_{11}
\end{array}
$$

3. On average, what proportion of your work time do you think should be devoted to actively providing information to users?

$$
\begin{array}{ccccccccccc}
0 \% & 10 \% & 20 \% & 30 \% & 40 \% & 50 \% & 60 \% & 70 \% & 80 \% & 90 \% & 100 \% \\
\square_{1} & \square_{2} & \square_{3} & \square_{4} & \square_{5} & \square_{6} & \square_{7} & \square_{8} & \square_{9} & \square_{10} & \square_{11}
\end{array}
$$




\section{New Extension Goals}

Listed below are several possible goals for the new Southern Interior extension program.

Please read through all of the items before you begin. Then rate each extension service goal where "10" equals those few items that are "very important" to you and a "1" equals those that are "very unimportant" to you. All others should be rated (circled) somewhere in between.

4. Extension services should focus on getting informa-

Very unimportant

$\begin{array}{llllllllll}1 & 2 & 3 & 4 & 5 & 6 & 7 & 8 & 9 & 10\end{array}$

5. The extension service should be able to link the person with a problem or question to those with the best available information.

6. The extension service should set up and run a central clearing house or "library" of resource management information.

7. Researchers within the Partnership should base their goals on the needs of the Partnership members.

8. The extension service should de-emphasize new research and focus instead on applying existing information to forest-management decisions.

9. The primary goal of extension services is to simplify and interpret technical information.

10. The extension service should focus on improving public knowledge about forest science and management.

11. The new extension service should provide support for individual and group decision-making processes.

12. Partnership researchers should focus on the interpretation of guidelines set out in the B.C. Forest Practices Code.

13. Extension services should focus on the scientific testing of guidelines set out in the B.C. Forest Practices Code.

14. Extension services should support the ongoing development of knowledge and research.

$$
\begin{array}{lllllllll}
1 & 2 & 3 & 4 & 5 & 6 & 7 & 8 & 9
\end{array}
$$

$\begin{array}{llllllllll}1 & 2 & 3 & 4 & 5 & 6 & 7 & 8 & 9 & 10\end{array}$

$\begin{array}{llllllllll}1 & 2 & 3 & 4 & 5 & 6 & 7 & 8 & 9 & 10\end{array}$

$\begin{array}{llllllllll}1 & 2 & 3 & 4 & 5 & 6 & 7 & 8 & 9 & 10\end{array}$

$\begin{array}{llllllllll}1 & 2 & 3 & 4 & 5 & 6 & 7 & 8 & 9 & 10\end{array}$

$\begin{array}{llllllllll}1 & 2 & 3 & 4 & 5 & 6 & 7 & 8 & 9 & 10\end{array}$
Very

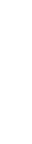


The following set of statements asks you to state your opinion about current extension services in your area. Please note whether you strongly disagree, disagree, agree, or strongly agree with the following statements.

15. Access to information: When seeking extension services, I'm generally able to access the needed information quickly.
Strongly disagree
Disagree
Agree
Strongly agree
$\square_{4}$
Don't know

16. Knowledge of responding personnel: I typically find that the persons I call upon to provide information are very knowledgeable.
Strongly disagree
Disagree
Agree
Strongly agree
Don't know
$\square$
$\square_{2}$
$\square_{3}$
$\square_{4}$
Q19.

17. Satisfaction with format: Current extension services generally provide information in a form that is clear and easy to follow.
Strongly disagree
Disagree
Agree
Strongly agree
Don't know
$\square_{1}$
$\square_{2}$
$\square_{3}$
$\square_{4}$
$\square_{9}$

18. Relevance of information: The information provided by extension services is often too general to address site-specific circumstances.

$\begin{array}{ccccc}\text { Strongly disagree } & \text { Disagree } & \text { Agree } & \text { Strongly agree } & \text { Don't know } \\ \square_{1} & \square_{2} & \square_{3} & \square_{4} & D_{9}\end{array}$

19. Relevance of information: The information provided by extension services is often too technically complex to address site-specific circumstances.

$\begin{array}{ccccc}\text { Strongly disagree } & \text { Disagree } & \text { Agree } & \text { Strongly agree } & \text { Don't know } \\ \square_{1} & \square_{2} & \square_{3} & \square_{4} & \square_{9}\end{array}$

20. Applicability of researcb: Overall, I think that members of the scientific community conduct work that directly addresses the information needs of the forest community.

Strongly disagree

口

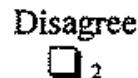

$\square_{2}$
Agree
Strongly agree

$\square_{4}$
Don't know

口9

21. Motivation: Members of the research community typically do not see extension services as a central part of their jobs.

Strongly disagree

0
Disagree

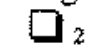

Agree
Strongly agree

]$_{4}$
Don't know O,

22. Responsiveness of research: Overall, the research community understands the questions and issues important to operators directly responsible for land management.

Strongly disagree

$\square_{1}$
Disagree

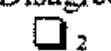

Agree

$\square_{3}$
Strongly agree

$\square_{4}$
Don't know 口。 
23. Integration of user ideas: Overall, the research community responds sufficiently to the questions generated by users when setting research priorities.
Strongly disagree
Disagree
$\square_{2}$
Agree
Strongly agree
Don't know
$\square_{4} \quad \square_{9}$

24. The introduction of the B.C. Forest Practices Code has increased the demand for extension services.

$\begin{array}{ccccc}\text { Strongly disagree } & \text { Disagree } & \text { Agree } & \text { Strongly agree } & \text { Don't krow } \\ \square_{1} & \square_{2} & \square_{3} & \square_{4} & \square_{9}\end{array}$

25. The use of Strategic Level land use plans (e.g., Land Resource Management Plans, Timber Supply Reviews, etc.) has increased the demand for extension services.

$\begin{array}{ccccc}\text { Strongly disagree } & \text { Disagree } & \text { Agree } & \text { Strongly agree } & \text { Don't know } \\ \square_{1} & \square_{2} & \square_{3} & \square_{4} & 9\end{array}$

26. I believe that, in the future, most Partnership members will be satisfied if they receive less person-toperson contact with extension agents and more access to computer technologies.

$\begin{array}{ccccc}\text { Strongly disagree } & \text { Disagree } & \text { Agree } & \text { Strongly agree } & \text { Don't know } \\ \square_{1} & \square_{2} & \square_{3} & \square_{4} & \square_{9}\end{array}$

27. In the past, when you have been faced with a guideline that needed interpreting or a landmanagement or job-related problem, where have you turned?

Please review this list and then check the three places where you most often find the information you need. (only 3 , please)

$\square_{1}$ Web pages or Internet

$\square_{2}$ Co-worker or colleague

$\square_{3}$ Librarian

$\square_{4}$ Professional journal or publication

$\square_{s}$ Government researcher already known to you

$\square_{6}$ Government researcher previously unknown to you

$\square_{7}$ College or university-based researcher already known to you

$\square_{8}$ College or university-based researcher previously unknown to you

$\square$, FRDA I and II Reports

$\square_{10}$ Agency reports or guidelines

$\square_{11}$ Extension agent

$\square_{12}$ Extension notes

$\square_{13}$ Newspapers, newsletters, or topic-specific magazines

$\square_{14}$ Contractor or consultant already known to you

$\square_{15}$ Contractor or consultant previously unknown to you

$\square_{16}$ Non-governmental organizations

$\square_{17}$ Nowhere. I didn't know where to turn.

$\square_{18}$ Other [please state] 
28. Who do you see as the primary users of the new Partnership extension service? Rate each member group as a low $(=1)$, medium $(=2)$ or high $(=3)$ user by circling the appropriate number.

1. Consultants

Low Middle High

2. Licencees

3. Contractors

4. Researchers - academic

\begin{tabular}{lll}
1 & 2 & 3 \\
1 & 2 & 3 \\
1 & 2 & 3 \\
\hline 1 & 2 & 3
\end{tabular}

5. Researchers - provincial or federal agency

\begin{tabular}{lll}
1 & 2 & 3 \\
1 & 2 & 3 \\
\hline 1 & 2 & 3
\end{tabular}

8. Ministry of Agriculture and Food

9. First Nation groups

10. Environmental organizations

\begin{tabular}{rrr}
1 & 2 & 3 \\
1 & 2 & 3 \\
\hline
\end{tabular}

11. General public

12. Value-added Businesses

13. Public school system and education institutions

$\begin{array}{lll}1 & 2 & 3 \\ 1 & 2 & 3 \\ 1 & 2 & 3 \\ 1 & 2 & 3\end{array}$

\section{Information Needs}

The following is a list of several broad categories of technical information. How frequently have you needed this kind of information in the last year? Please circle the number that reflects your answer for each category of information.

\section{Knowledge about:}

Never Rarely sionally Often

29. Harvesting techniques in environmentally sensitive locations

30. Riparian management

31. Community watershed management

32. Domestic watershed assessment

33. Mixed species management

34. Ecological classifications and inventories

35. First Nation uses of particular sites

\begin{tabular}{llll}
1 & 2 & 3 & 4 \\
\hline 1 & 2 & 3 & 4
\end{tabular}

$1 \quad 2 \quad 3 \quad 4$

$12 \quad 2 \quad 3 \quad 4$


Knowledge about:

Never Rarely sionally Often

36. Fisheries inventories

\begin{tabular}{cccc}
1 & 2 & 3 & 4 \\
1 & 2 & 3 & 4 \\
1 & 2 & 3 & 4 \\
\hline 1 & 2 & 3 & 4 \\
1 & 2 & 3 & 4
\end{tabular}

41. Safety of particular forest-management actions (e.g., fungicide applications, pesticide use, ground covers, controlled burning, etc.)

42. Defining old growth

\begin{tabular}{llll}
\hline 1 & 2 & 3 & 4 \\
1 & 2 & 3 & 4 \\
1 & 2 & 3 & 4 \\
1 & 2 & 3 & 4 \\
\hline 1 & 2 & 3 & 4 \\
1 & 2 & 3 & 4 \\
1 & 2 & 3 & 4 \\
1 & 2 & 3 & 4 \\
\hline 1 & 2 & 3 & 4
\end{tabular}

50. Defining critical habitat

51. Strategic level planning processes (e.g. LRMP, TSR, Landscape Unit Planning)

$\begin{array}{llll}1 & 2 & 3 & 4\end{array}$

52. Silvicultural systems

$\begin{array}{llll}1 & 2 & 3 & 4\end{array}$


The following is a list of several broad categories of social forestry information. How frequently have you needed this kind of information in the last year (never, rarely, occasionally or often)?

53. Economic cost-benefit information:

$\begin{array}{cccc}\text { Never } & \text { Rarely } & \text { Occasionally } & \text { Often } \\ \square_{1} & \square_{2} & \square_{3} & \square_{4}\end{array}$

54. Nonmarket resource values:

$\begin{array}{cccc}\text { Never } & \text { Rarely } & \text { Occasionally } & \text { Often } \\ \square_{1} & \square_{2} & \square_{3} & \square_{4}\end{array}$

55. Population trends:

$\begin{array}{cccc}\text { Never } & \text { Rarely } & \text { Occasionally } & \text { Often } \\ \square_{1} & \square_{2} & \square_{3} & \square_{4}\end{array}$

56. Recreational values:

$\begin{array}{cccc}\text { Never } & \text { Rarely } & \text { Occasionally } & \text { Often } \\ \square_{1} & \square_{2} & \square_{3} & \square_{4}\end{array}$

57. Tourist expenditures:

$\begin{array}{cccc}\text { Never } & \text { Rarely } & \text { Occasionally } & \text { Often } \\ \square_{1} & \square_{2} & \square_{3} & \square_{4}\end{array}$

58. Community, social, and demographic indicators:

$\begin{array}{cccc}\text { Never } & \text { Rarely } & \text { Occasionally } & \text { Often } \\ \square_{1} & \square_{2} & \square_{3} & \square_{4}\end{array}$

59. Information about cuitural values:

$\begin{array}{cccc}\text { Never } & \text { Rarely } & \text { Occasionally } & \text { Often } \\ \square_{1} & \square_{2} & \square_{3} & \square_{4}\end{array}$


The following is a list of several types of information relating to the British Columbia Forest Practices Code. How frequently have you needed this kind of information in the last year?

60. Legal obligations and responsibilities under the Forest Practices Code:

$\begin{array}{cccc}\text { Never } & \text { Rarely } & \text { Occasionally } & \text { Often } \\ \square & \square_{2} & \square_{3} & \square_{4}\end{array}$

61. Technical advice on "best practices":

$\begin{array}{cccc}\text { Never } & \text { Rarely } & \text { Occasionally } & \text { Often } \\ \square_{1} & \square_{2} & \square_{3} & \square \square_{4}\end{array}$

62. Technical advice on specific management applications:

$\begin{array}{cccc}\text { Never } & \text { Rarely } & \text { Occasionally } & \text { Often } \\ \square & \square_{2} & \square_{3} & \square_{4}\end{array}$

63. Levels of actions needed to achieve environmentally sustainable practices:

$\begin{array}{cccc}\text { Never } & \text { Rarely } & \text { Occasionally } & \text { Often } \\ \square_{1} & \square_{2} & \square_{3} & \square \square_{4}\end{array}$

The following is a list of several types of information relating to defining problems and making decisions. How frequently have you needed this kind of information in the last year?

64. Case study examples of forest practices at comparable sites:

$\begin{array}{cccc}\text { Never } & \text { Rarely } & \text { Occasionally } & \text { Often } \\ \square & \square & \square_{3} & \square\end{array}$

65. Sample silvicultural prescriptions:

$\begin{array}{cccc}\text { Never } & \text { Rarely } & \text { Occasionally } & \text { Often } \\ \square_{1} & \square_{2} & \square_{3} & \square_{4}\end{array}$

66. Setting up and running consultations with stakeholders:
Never
Rarely
Occasionally
$\square_{3}$
Often

67. Decision tools for choosing among resource-management actions:
Never
Rarely
Occasionally
Often
$\Xi_{3}$
$\square$

68. Decision tools for setting operations priorities:

$\begin{array}{cccc}\text { Never } & \text { Rarely } & \text { Occasionally } & \text { Often } \\ \square & \Xi_{2} & \square_{3} & \square_{4}\end{array}$




\section{Extension Access}

This set of questions describes possible limits to your use of extension services. Please state whether you strongly disagree, disagree, agree, or strongly agree with the following statements.

69. It's often hard to figure out who the knowledgeable person is on a topic.

$\begin{array}{ccccc}\text { Strongly disagree } & \text { Disagree } & \text { Agree } & \text { Strongly agree } & \text { Don't know } \\ \square & \square_{2} & \square_{3} & \square_{4} & \square_{9} .\end{array}$

70. I don't know how to determine what information is already available on a topic.

$\begin{array}{ccccc}\text { Strongly disagree } & \text { Disagree } & \text { Agree } & \text { Strongly agree } & \text { Don't know } \\ \square_{5} & \square_{2} & \square_{3} & \square_{4} & \square_{9}\end{array}$

71. I don't feel comfortable contacting the knowledgeable or expert person unless I already know them.

$\begin{array}{ccccc}\text { Strongly disagree } & \text { Disagree } & \text { Agree } & \text { Strongly agree } & \text { Don't know } \\ \square_{1} & \square_{2} & \square_{3} & \square_{4} & \square_{9}\end{array}$

72. There is a limited supply of the most commonly used extension materials.

$\begin{array}{ccccc}\text { Strongly disagree } & \text { Disagree } & \text { Agree } & \text { Strongly agree } & \text { Don't know } \\ \square & \square_{2} & \square_{3} & \square_{4} & \square_{9}\end{array}$

73. There is no one within my organization to help me set up extension contacts.

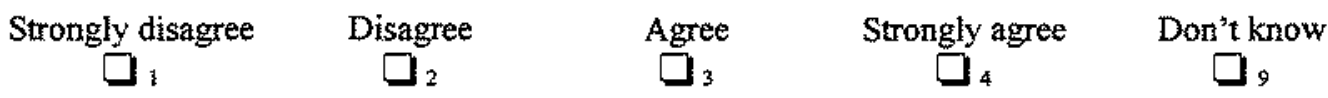

74. Available information rarely applies directly to my specific problem.

$\begin{array}{ccccc}\text { Strongly disagree } & \text { Disagree } & \text { Agree } & \text { Strongly agree } & \text { Don't know } \\ \square & \square_{2} & \square_{3} & \square_{4} & \square_{9}\end{array}$

75. Getting time away from my current job to attend workshops, site visits or courses is too difficult.

Strongly disagree $\quad$ Disagree $\quad$ Agree $\quad$ Strongly agree $\quad$ Don't know


76. New extension services should operate on a "fee-for-service" basis.

Strongly disagree $\square_{1}$
Disagree

$\square_{2}$
Agree

$\square_{3}$
Strongly agree

$\square_{4}$
Don't know

$\square$,

77. New extension services should operate on a "cost-recovery" basis provided through Partnership member dues.

Strongly disagree in
Disagree

$\square_{2}$
Agree

Strongly agree

$\square{ }_{4}$
Don't know

\section{Research-Operation Linkages}

This next set of questions asks you to evaluate the link between research and applied use of that research. Do you strongly disagree, disagree, agree, or strongly agree with the following statements?

78. The research community currently does a good job of responding to the different cultures and learning styles.

Strongly disagree

$\square_{1}$
Disagree
$\square$
Agree
$\square$
Strongly agree

$\square_{4}$
Don't know

$\square_{3}$

79. The time lag between the start of a research project and the release of field applications is too great.

Strongly disagree $\square$ :
Disagree

$\square_{2}$
Agree
Strongly agree

Don't know

$\square_{9}$

80. I think researchers should be more forthcoming with preliminary results when field workers need help.

Strongly disagree

!
Disagree

$\square_{2}$
Agree
Strongly agree

$\square_{4}$
Don't know

$\square_{9}$

81. The research community does too much long-term research and not enough to address shortterm problems.

Strongly disagree

$\square_{\mathrm{I}}$
Disagree

$\square_{2}$ $\stackrel{\text { Agree }}{\square}$
Strongly agree

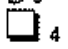

Don't know

$\square$, 


\section{Modes of Delivery}

Please rate the following vehicles for getting information from its source to those likely to use that information. Circle the appropriate number on each of the five lines or scales that follow every question.

82. Extension notes in four pages or less:

$$
\begin{array}{rll}
\text { Will not reach key personnel } & 1-2-3-4-5 & \text { Will reach key personnel } \\
\text { Not likely to be used } & 1-2-3-4-5 & \text { Likely to be used } \\
\text { Reaches small audience } & 1-2-3-4-5 & \text { Reaches large audience } \\
\text { Not user friendly } & 1-2-3-4-5 \text { User friendly } \\
\text { Low priority given limited funding } & 1-2-3-4-5 \text { High priority given limited funding }
\end{array}
$$

83. On-site visits by extension personnel:

$$
\begin{array}{rll}
\text { Will not reach key personnel } & 1-2-3-4-5 & \text { Will reach key personnel } \\
\text { Not likely to be used } & 1-2-3-4-5 & \text { Likely to be used } \\
\text { Reaches small audience } & 1-2-3-4-5 \text { Reaches large audience } \\
\text { Not user friendly } & 1-2-3-4-5 \text { User friendly } \\
\text { Low priority given limited funding } & 1-2-3-4-5 \text { High priority given limited funding }
\end{array}
$$

84. Toll-free information lines to extension agents:

$$
\begin{array}{rll}
\text { Will not reach key personnel } & 1-2-3-4-5 & \text { Will reach key personnel } \\
\text { Not likely to be used } & 1-2-3-4-5 & \text { Likely to be used } \\
\text { Reaches small audience } & 1-2-3-4-5 \text { Reaches large audience } \\
\text { Not user friendly } & 1-2-3-4-5 \text { User friendly } \\
\text { Low priority given limited funding } & 1-2-3-4-5 \text { High priority given limited funding }
\end{array}
$$

85. Computer web sites that are regularly updated:

$$
\begin{array}{rll}
\text { Will not reach key personnel } & 1-2-3-4-5 & \text { Will reach key personnel } \\
\text { Not likely to be used } & 1-2-3-4-5 & \text { Likely to be used } \\
\text { Reaches small audience } & 1-2-3-4-5 & \text { Reaches large audience } \\
\text { Not user friendly } & 1-2-3-4-5 & \text { User friendly }
\end{array}
$$

Low priority given limited funding $1-2-3-4-5$ High priority given limited funding 


\section{Modes of Delivery, cont.}

86. Interpretive guides and field guides:

Will not reach key personnel $1-2-3-4-5$ Will reach key personnel

Not likely to be used $1-2-3-4-5$ Likely to be used

Reaches small audience $1-2-3-4-5$ Reaches large audience

Not user friendly $1-2-3-4-5$ User friendly

Low priority given limited funding $1-2-3-4-5$ High priority given limited funding

87. Government research reports:

Will not reach key personnel $1-2-3-4-5$ Will reach key personnel

Not likely to be used $1-2-3-4-5$ Likely to be used

Reaches small audience $1-2-3-4-5$ Reaches large audience

Not user friendly $1-2-3-4-5$ User friendly

Low priority given limited funding $1-2-3-4-5$ High priority given limited funding

88. Field days at regional demonstration forests:

Will not reach key personnel $1-2-3-4-5$ Will reach key personnel

Not likely to be used $1-2-3-4-5$ Likely to be used

Reaches small audience $1-2-3-4-5$ Reaches large audience

Not user friendly $1-2-3-4-5$ User friendly

Low priority given limited funding $1-2-3-4-5$ High priority given limited funding

89. Journal articles:

Will not reach key personnel $1-2-3-4-5$ Will reach key personnel

Not likely to be used $1-2-3-4-5$ Likely to be used

Reaches small audience $1-2-3-4-5$ Reaches large audience

Not user friendly $1-2-3-4-5$ User friendly

Low priority given limited funding $1-2-3-4-5$ High priority given limited funding 


\title{
Modes of Delivery, cont.
}

90. Directory of Partnership research projects containing one-paragraph abstracts about likely applications:

\author{
Will not reach key personnel $1-2-3-4-5$ Will reach key personnel \\ Not likely to be used $1-2-3-4-5$ Likely to be used \\ Reaches small audience $1-2-3-4-5$ Reaches large audience \\ Not user friendly $1-2-3-4-5$ User friendly \\ Low priority given limited funding $1-2-3-4-5$. High priority given limited funding
}

91. Instructional half-hour videos:
Will not reach key personnel $1-2-3-4-5$
Not likely to be used $1-2-3-4-5$
Will reach key personnel
Reaches small audience $1-2-3-4-5$ Reaches large audience
Not user friendly $1-2-3-4-5$ User friendly
Low priority given limited funding $1-2-3-4-5$ High priority given limited funding

92. Workshops with field components:
Will not reach key personnel $1-2-3-4-5$ Will reach key personnel
Not likely to be used $1-2-3-4-5$ Likely to be used
Reaches small audience $1-2-3-4-5$ Reaches large audience
Not user friendly $1-2-3-4-5$ User friendly
Low priority given limited funding $1-2-3-4-5$ High priority given limited funding

93. Partnership extension specialists:
Will not reach key personnel $1-2-3-4-5$ Will reach key personnel
Not likely to be used $1-2-3-4-5$ Likely to be used
Reaches small audience $1-2-3-4-5$ Reaches large audience
Not user friendly $1-2-3-4-5$ User friendly

Low priority given limited funding $1-2-3-4-5$ High priority given limited funding 


\title{
Modes of Delivery, cont.
}

94. Professional conferences:

Will not reach key personnel $1-2-3-4-5$ Will reach key personnel

Not likely to be used $1-2-3-4-5$ Likely to be used

Reaches small audience $1-2-3-4-5$ Reaches large audience

Not user friendly $1-2-3-4-5$ User friendly

Low priority given limited funding $1-2-3-4-5$ High priority given limited funding

95. One-page summaries of joumal articles:

Will not reach key personnel $1-2-3-4-5$ Will reach key personnel

Not likely to be used $1-2-3-4-5$ Likely to be used

Reaches small audience $1-2-3-4-5$ Reaches large audience

Not user friendly $1-2-3-4-5$ User friendly

Low priority given limited funding $1-2-3-4-5$ High priority given limited funding

96. One-page 'picture' demonstrations of new techniques:

\author{
Will not reach key personnel $1-2-3-4-5$ Will reach key personnel \\ Not likely to be used $1-2-3-4-5$ Likely to be used \\ Reaches small audience $1-2-3-4-5$ Reaches large audience \\ Not user friendly $1-2-3-4-5$ User friendly \\ Low priority given limited funding $1-2-3-4-5$ High priority given limited funding
}

97. Internet question-answer bulletin boards:

Will not reach key personnel $1-2-3-4-5$ Will reach key personnel

Not likely to be used $1-2-3-4-5$ Likely to be used

Reaches small audience $1-2-3-4-5$ Reaches large audience

Not user friendly $1-2-3-4-5$ User friendly

Low priority given limited funding $1-2-3-4-5$ High priority given limited funding 


\section{Quality of Information}

Please read over the following list. How much trust do you have in each one as an information source about forest and range management topics? Please circle your response for each question-item.

98. Web page-Ministry of Forests (MOF)

$\begin{array}{ccccc}\text { Alnost } & \text { A little } & \text { A fair } & \\ \text { amount } & \text { A lot } & \text { Don't } \\ \text { no trust } & \text { trust } & \text { of trust } & \text { of trust } & \text { know }\end{array}$

99. Web page - Ministry of Environment, Lands and Parks (MELP)

$\begin{array}{llllll}1 & 2 & 3 & 4 & 9\end{array}$

$\begin{array}{lllll}1 & 2 & 3 & 4 & 9\end{array}$

100. Web page - Ministry of Agriculture and Food (MAF)

$\begin{array}{lllll}1 & 2 & 3 & 4 & 9\end{array}$

101. Web page - university or college

102. Web page - individual researcher

\begin{tabular}{lllll}
1 & 2 & 3 & 4 & 9 \\
\hline 1 & 2 & 3 & 4 & 9
\end{tabular}

103. Internet

104. Co-worker or colleague

105. Librarian

106. Professional journal or publication

107. Academic or government researcher already known to you

\begin{tabular}{lllll}
1 & 2 & 3 & 4 & 9 \\
1 & 2 & 3 & 4 & 9 \\
1 & 2 & 3 & 4 & 9 \\
\hline 1 & 2 & 3 & 4 & 9
\end{tabular}

$\begin{array}{lllll}1 & 2 & 3 & 4 & 9\end{array}$

108. Academic or government researcher previously unknown to you

109. Agency reports-MOF

110. Agency reports - MELP

111. Agency reports - MAF

112. Agency reports - Canadian Forest Service

113. Agency reports - Agriculture Canada

114. Extension specialist

115. Extension notes

116. Newspapers or topic-specific magazines

117. Newsletters

118. Contractor or consultant already known to you

119. Contractor or consultant previously unknown to you

\begin{tabular}{lllll}
1 & 2 & 3 & 4 & 9 \\
\hline 1 & 2 & 3 & 4 & 9
\end{tabular}

$\begin{array}{lllll}1 & 2 & 3 & 4 & 9\end{array}$

\begin{tabular}{lllll}
1 & 2 & 3 & 4 & 9 \\
1 & 2 & 3 & 4 & 9 \\
\hline 1 & 2 & 3
\end{tabular}




\section{First Nation Concerns}

Extension services potentially include the development and exchange of information among culturally distinct groups, for instance, exchanges among First Nation groups, government resource management agencies, and private sector companies within the Partnership.

Bearing this in mind, please tell us whether you strongly disagree, disagree, agree, or strongly agree with the following statements.

120. First Nation knowledge about traditional land-management practices should be given equivalent status when compared to scientific information.

$\begin{array}{ccccc}\text { Strongly disagree } & \text { Disagree } & \text { Agree } & \text { Strongly agree } & \text { Don't know } \\ \square_{1} & \square_{2} & \square_{3} & \square_{4} & \square_{9}\end{array}$

121. Generally speaking, First Nation groups should not discuss traditional use knowledge with non-Native Partnership members.

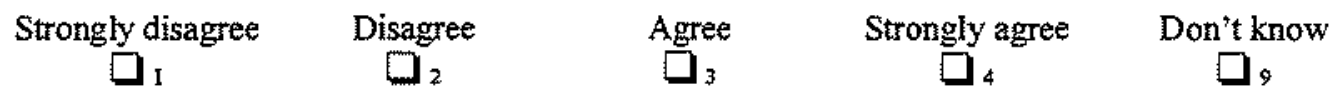

122. The recent "Delgamuuk" decision in the federal courts increases the demand for extension services specific to the needs of First Nation groups.

Strongly disagree Disagree Agree $\square_{1} \quad \square_{2} \quad \square_{3}$

Strongly agree $\quad$ Don't know

Do you strongly disagree, disagree, agree, or strongly agree that the new extension service should support (via personnel, equipment and education) First Nation efforts to develop the following information and facilities?

123. Computer facilities:

Strongly disagree

I:
Disagree

$\square_{2}$
Agree

$\boldsymbol{\beth}_{3}$
Strongly agree

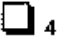

Don't know

$\square 9$

124. Case studies of sustainable timber practices:

Strongly disagree

$\square_{1}$
Disagree

$\square_{2}$
Agree

$\square_{3}$
Strongly agree

$\square_{4}$
Don't know

$\square_{9}$

125. Information about sustainable nontimber forest uses:

Strongly disagree

$\square$
Disagree
Agree
Strongly agree

$\square_{4}$
Don't know

$\square$ ? 
126. The development of records (archeological, oral histories, etc.) that clarify traditional uses in certain territories (as this relates to aboriginal resource development):

$\begin{array}{ccccc}\text { Strongly disagree } & \text { Disagree } & \text { Agree } & \text { Strongly agree } & \text { Don't know } \\ \square & \square_{2} & \square_{3} & \square_{4} & \square_{9}\end{array}$

127. Journal subscriptions:

$\begin{array}{ccccc}\text { Strongly disagree } & \text { Disagree } & \text { Agree } & \text { Strongly agree } & \text { Don't know } \\ \square_{1} & \square_{2} & \square_{3} & \square_{4} & \square\end{array}$

128. Animal and plant inventories:

$\begin{array}{ccccc}\text { Strongly disagree } & \text { Disagree } & \text { Agree } & \text { Strongly agree } & \text { Don't know } \\ \square_{1} & \square_{2} & \square_{3} & \square_{4} & \square_{9}\end{array}$

\section{Technology Transfer Priorities}

Tough choices and tradeoffs need to be made to more fully develop new extension services. The list below presents pairs of possible extension priorities. Please consider both items and select the one in each pair that you consider most important. Indicate your choice by checking the box to the left of the higher-priority selection.

129. $\square$, Regularly updated agency internet web pages (MOF, MELP, etc.); OR

$\square_{2}$ Extension notes (4 pages or less)

130.

$\square_{2}$ Toll-free information lines to extension agents

131. $\square$, Reprints of journal articles on topics of interest; OR

$\square_{2}$ A directory of recent case studies accompanied by short statements about their application

132. $\square$, Instructional half-hour videos; $O R$

$D_{2}$ Workshops at regional demonstration forests

133. $\square$, Professional conferences; $O R$

$\square_{2}$ Newsletter summarizing recent conferences and journal publications

134. $\square$ : One-page picture demonstrations of new techniques; OR

$\square_{2}$ Internet question-answer bulletin boards

135. $\square$, Computer models; OR

${ }_{2}$ Interpretive guides, field guides, or government research reports 


\section{Location of Extension Staff}

This set of choices asks you to choose between different types and locations of extension staff. We do not mean to promise that personnel of this kind will be hired. Your answers will simply heip us understand the kinds of support staff you think might contribute most to the development and use of extension services.

\section{Choose one:}

136. $\square$, A skilled librarian capable of responding to requests for materials on land- and resourcemanagement. He or she would potentially reside in the Southern Interior, and be available through a toll-free line, fax, or email.

\section{OR}

$\square_{2}$ A skilled networker capable of linking a person with a research or operations question to the individual within the Partnership best able to answer questions. He or she would reside in the Southem Interior, but be available through a toll-free line, fax, or email.

\section{OR}

\section{Choose one:}

137. $\square_{1}$ A small number of highly skilled extension agents, working in the vicinity of Nelson, Kamloops, or Williams Lake, capable of answering very specific questions about the management of resources.

\section{OR}

$\beth_{2}$ A larger number of moderately skilled extension agents capable of answering basic questions about the management of resources. These individuals would work in the vicinity of the Nelson, Kamloops, and/or Williams Lake.

\section{OR}

$\square_{3}$ A small number of highly skilled extension agents working out of Victoria capable of answering very specific questions about the management of resources. 


\section{Background Information}

138. What is your age?

139. What is your gender? $\square_{1}$ Male $\square_{2}$ Female

140. What is your highest level of education earned?

$\begin{array}{ll}\square \text { 岁 Less than high school diploma } & \square_{5} \text { Masters } \\ \square_{2} \text { High school diploma } & \square_{6} \text { Ph.D. } \\ \square_{3} \text { College diploma } & \square_{7} \text { Other (please specify): } \\ \square_{4} \text { Bachelors degree } & \end{array}$

141. Year in which your highest degree was received:

142. How many years have you been with your current company or organization?

143. Please state your current job title:

144. Please check the city or town closest to your place of work:
D. Vancouver
4 Kamloops
$\square_{2}$ Victoria
\$ Williams Lake
$\square_{3}$ Nelson

\section{Additional Comments}

We know that you have put a great deal of effort into this survey and we thank you for your time. If you have additional comments, please state them here. 


\section{Appendix B: Cost Considerations}




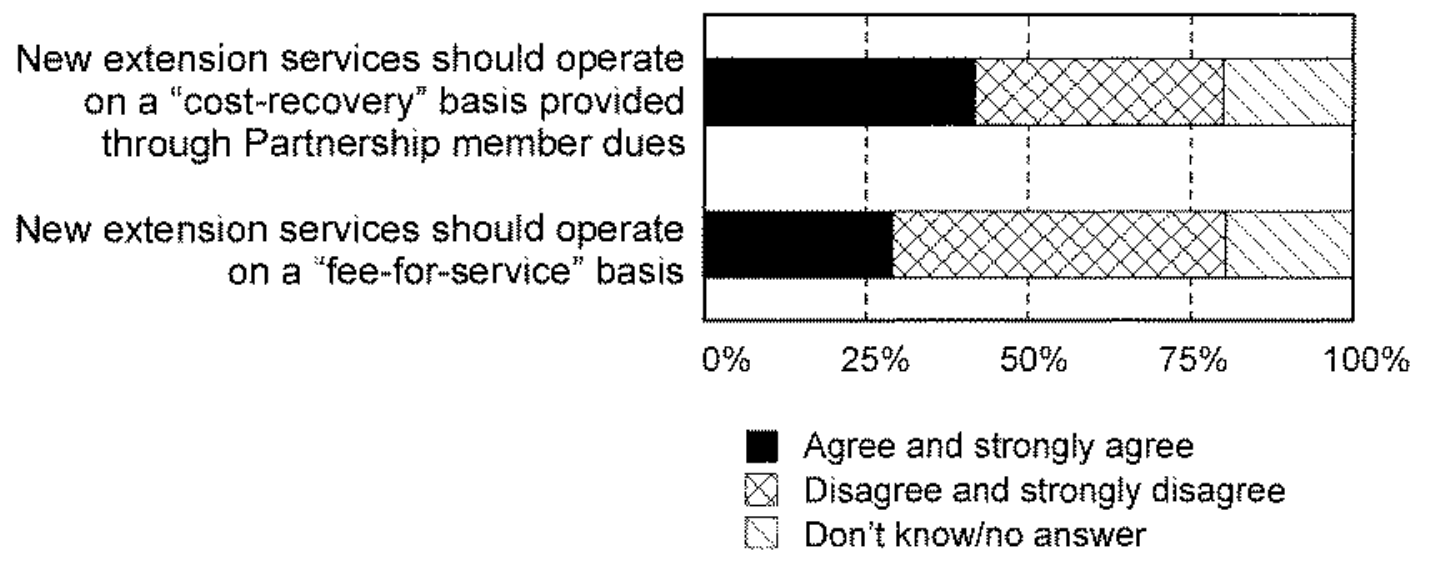

Figure B.1. Cost considerations $(\mathrm{N}=391)$. Source: Decision Research, Southern Interior Forest Extension Survey (1998).

cyni terretmof graphics $\backslash \mathrm{B}-1, \mathrm{cdr}$ 9-25-98 
New extension services should operate on a "cost-recovery" basis provided through Partnership member dues.

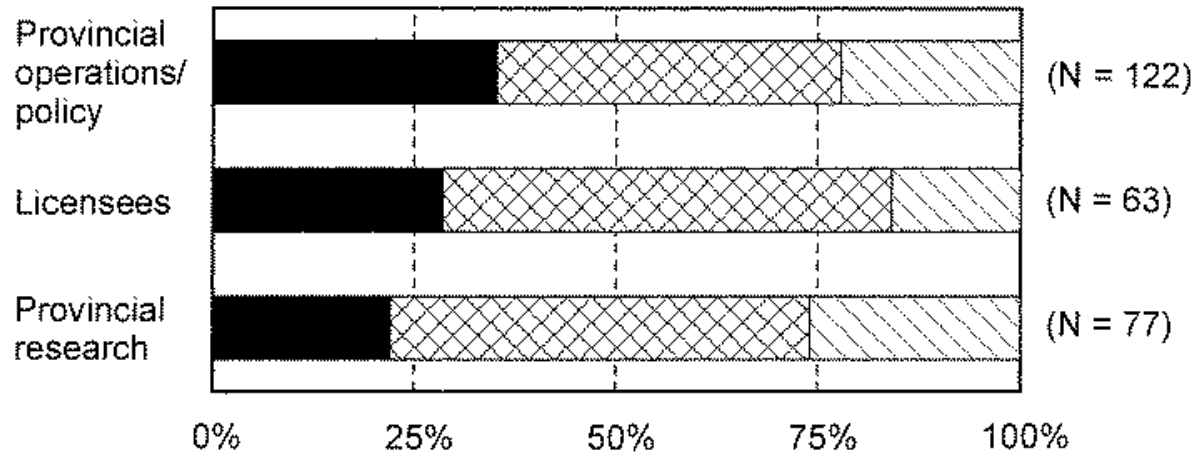

New extension services should operate on a "fee-for-service" basis.

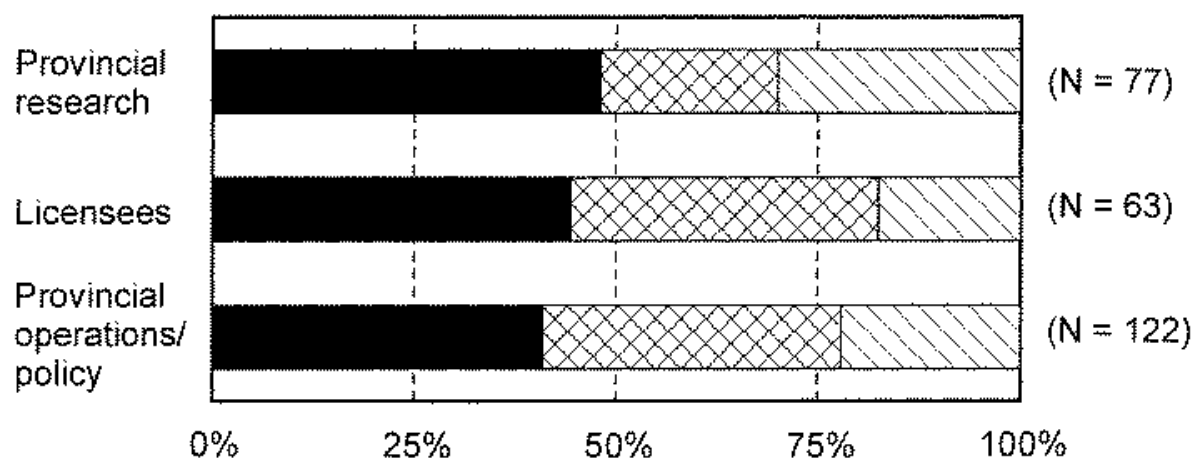

Agree and strongly agree

$\otimes$ Disagree and strongly disagree

15 Don't know/no answer

Figure B.2. Cost considerations for three groups. Source: Decision Research, Southern Interior Forest Extension Survey (1998).

cym tereinOF graphics 
New extension services should operate on a "cost-recovery" basis provided through Partnership member dues.

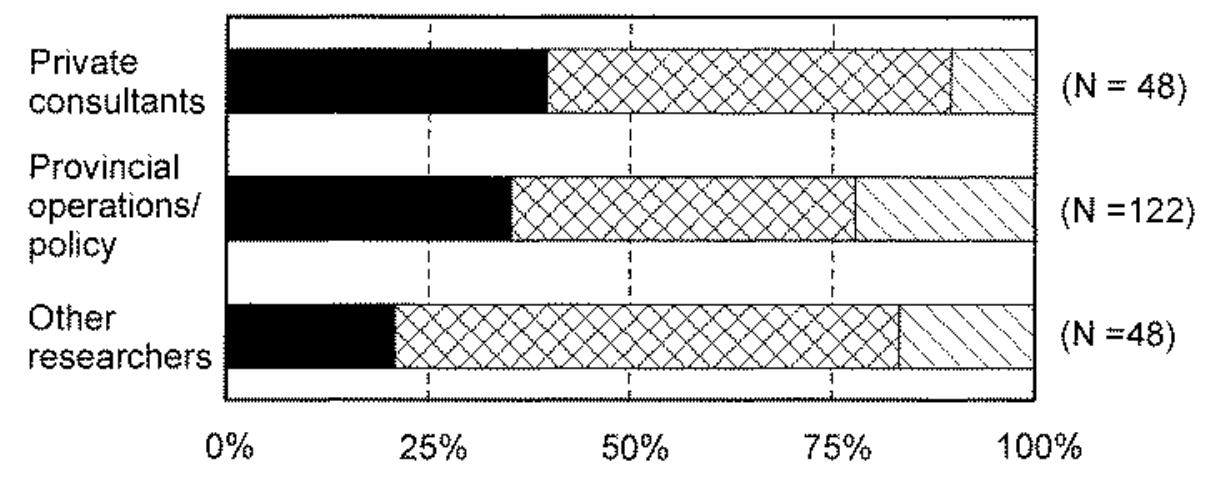

New extension services should operate on a "fee-for-service" basis.

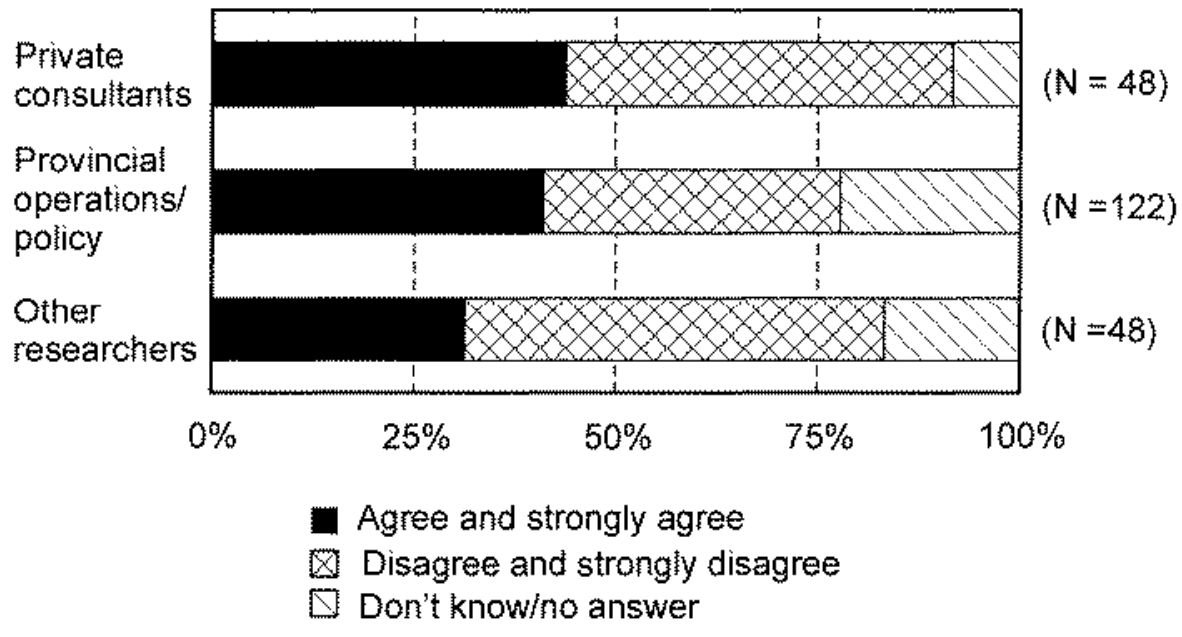

Figure B.3. Cost considerations for three groups. Source: Decision Research, Southern Interior Forest Extension Survey (1998).

cynt terrewOF graphicsłB-3.cdr 9-25-98 